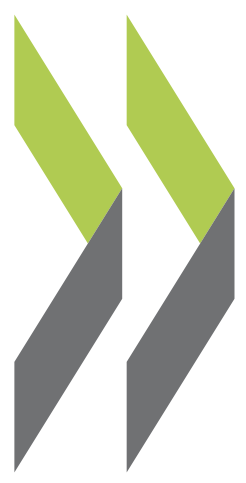

OECD Economics Department Working Papers No. 1485

\title{
Structural policies to boost productivity and inclusion in Costa Rica
} Lisa Meehan 


\section{STRUCTURAL POLICIES TO BOOST PRODUCTIVITY AND INCLUSION IN} COSTA RICA

\section{ECONOMICS DEPARTMENT WORKING PAPERS No. 1485}

By Lisa Meehan

OECD Working Papers should not be reported as representing the official views of the OECD or of its member countries. The opinions expressed and arguments employed are those of the author(s).

Authorised for publication by Isabell Koske, Deputy Director, Country Studies Branch, Economics Department.

All Economics Department Working Papers are available at www.oecd.org/eco/workingpapers.

JT03434258 
OECD Working Papers should not be reported as representing the official views of the OECD or of its member countries. The opinions expressed and arguments employed are those of the author(s).

Working Papers describe preliminary results or research in progress by the author(s) and are published to stimulate discussion on a broad range of issues on which the OECD works.

Comments on Working Papers are welcomed, and may be sent to OECD Economics Department, 2 rue André Pascal, 75775 Paris Cedex 16, France, or by e-mail to eco.contact@oecd.org.

All Economics Department Working Papers are available at www.oecd.org/eco/workingpapers.

This document and any map included herein are without prejudice to the status of or sovereignty over any territory, to the delimitation of international frontiers and boundaries and to the name of any territory, city or area.

The statistical data for Israel are supplied by and under the responsibility of the relevant Israeli authorities. The use of such data by the OECD is without prejudice to the status of the Golan Heights, East Jerusalem and Israeli settlements in the West Bank under the terms of international law.

On 3 May 2018, the OECD Council invited Lithuania to become a Member. At the time of publication the deposit of Lithuania's instrument of accession to the OECD Convention was pending and therefore Lithuania does not appear in the list of OECD Members and is not included in the OECD zone aggregates.

On 25 May 2018, the OECD Council invited Colombia to become a Member. At the time of publication the deposit of Colombia's instrument of accession to the OECD Convention was pending and therefore Colombia does not appear in the list of OECD Members and is not included in the OECD zone aggregates.

\section{(C) OECD (2018)}

You can copy, download or print OECD content for your own use, and you can include excerpts from OECD publications, databases and multimedia products in your own documents, presentations, blogs, websites and teaching materials, provided that suitable acknowledgment of OECD as source and copyright owner is given. All requests for commercial use and translation rights should be submitted to rights@oecd.org 


\begin{abstract}
RESUME
Structural policies to boost productivity and inclusion in Costa Rica

Owing to past structural reforms, Costa Rica has enjoyed robust GDP growth and productivity levels are gradually converging towards the OECD average. However, large GDP per capita and productivity gaps persist. In addition, not everyone has benefited from this growth. Inequality has increased and labour market conditions are a concern. Costa Rica has a lower share of employed workers in the population than almost all OECD countries, unemployment remains well above its pre-global-financial-crisis level, labour market participation has decreased and the share of informal jobs is high. Recognising these challenges, Costa Rica has accelerated its structural reform momentum recently, with policy reforms underway or planned in several areas that present win-win opportunities to boost both productivity and inclusion. These include efforts to tackle labour market informality, simplify the minimum wage structure, increase competition and reduce regulatory burdens. In addition to further reforms in these priority areas, structural policy improvements are also needed to increase outcomes and reduce inequalities in education and address significant transport infrastructure gaps.
\end{abstract}

This Working Paper relates to the 2018 OECD Economic Survey of Costa Rica.

JEL Classification: I28; I31; J14; J16; J21; J24; J32; J46; J48; J58; L40; L51; L53; O18; O33; O38; R48

Keywords: Costa Rica; productivity; inclusive growth

$* * * * * * * * *$

\title{
Renforcer la productivité et l'inclusion en s'appuyant sur les politiques structurelles au Costa Rica
}

Grâce aux réformes structurelles antérieures, le Costa Rica a bénéficié d'une croissance vigoureuse du produit intérieur brut (PIB) et son niveau de productivité converge progressivement vers la moyenne de l'OCDE. Néanmoins, d'amples écarts de PIB par habitant et de productivité perdurent. En outre, tout le monde n'a pas récolté les fruits de cette croissance. Les inégalités se sont accentuées et la situation du marché du travail est préoccupante. La proportion d'actifs occupés dans la population est plus faible au Costa Rica que dans la quasi-totalité des pays de l'OCDE, le chômage demeure nettement supérieur au niveau auquel il s'établissait avant la crise financière mondiale, le taux d'activité a diminué et la proportion d'emplois informels est élevée. Conscientes de ces problèmes, les autorités costaricaines ont accéléré récemment le rythme de leurs réformes structurelles, et dans plusieurs domaines sont mises en œuvre ou prévues des réformes doublement fructueuses, qui devraient permettre à la fois de renforcer la productivité et l'inclusion. On peut citer à cet égard les efforts déployés en vue de faire reculer l'emploi informel, de simplifier la structure des salaires minimums, de renforcer la concurrence et de réduire le poids de la réglementation. Outre des réformes complémentaires dans ces domaines prioritaires, des améliorations des politiques structurelles sont également nécessaires pour améliorer les résultats et réduire les inégalités dans le domaine de l'éducation, et pour remédier aux carences importantes des infrastructures de transport.

Ce document de travail est lié à l'Étude économique de l'OCDE de 2018 consacrée au Costa Rica. Classification JEL: I28; I31; J14; J16; J21; J24; J32; J46; J48; J58; L40; L51; L53; O18; O33; O38; R48 Mots-clés : Costa Rica ; productivité ; croissance inclusive 


\section{Table of contents}

Structural policies to boost productivity and inclusion in Costa Rica............................................... 6

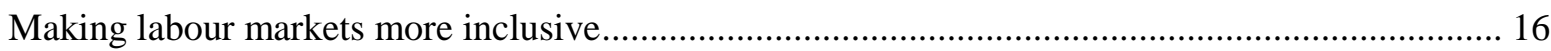

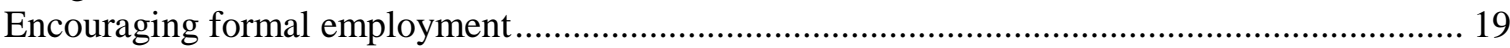

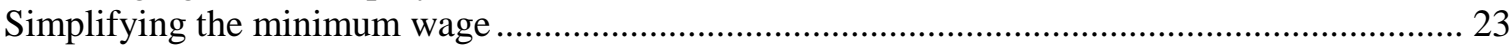

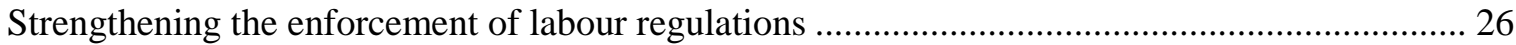

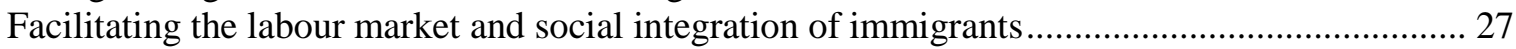

Enhancing the quality and efficiency of the education system ...................................................... 28

Making educational outcomes the main policy target and re-balance the spending mix ................ 31

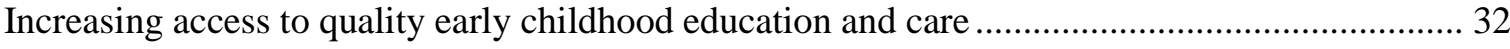

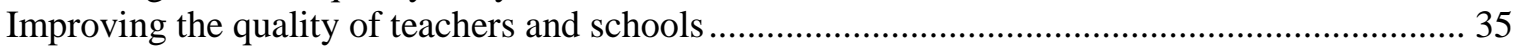

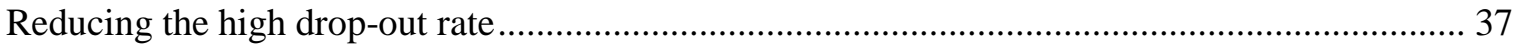

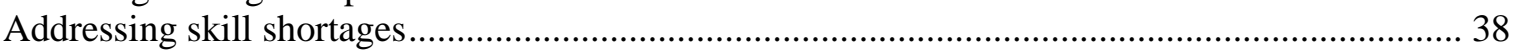

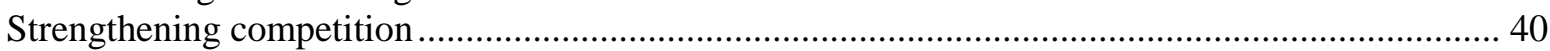

Granting the competition authority more independence and resources ..................................... 40

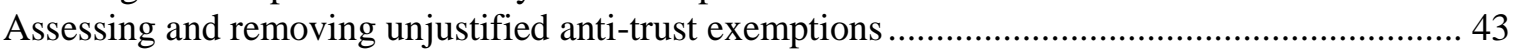

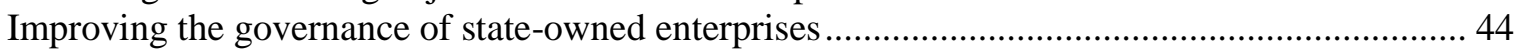

Reducing barriers to entrepreneurship and streamlining regulatory procedures ............................. 46

Improving the insolvency regime to facilitate the exit of "zombie" firms ..................................... 47

Continuing efforts to increase the profile and coordination of productivity-related policies......... 48

Promoting innovation, technological diffusion and integration into global value chains.................. 48

Strengthening coordination to increase firm linkages and the contribution of public research to

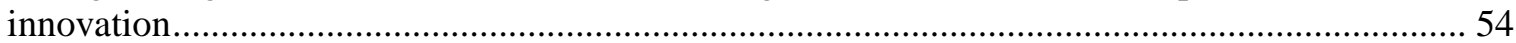

Boosting regional integration through improved trade facilitation ............................................ 55

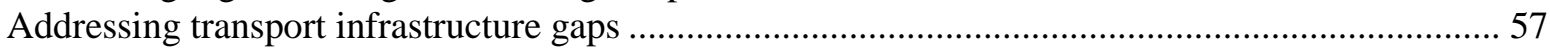

Streamlining the institutional framework for transport infrastructure investment ..........................5 59

Reforming institutional settings to improve the governance of private sector investment ............ 60

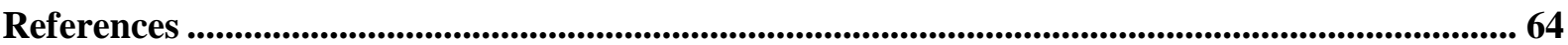

\section{Tables}

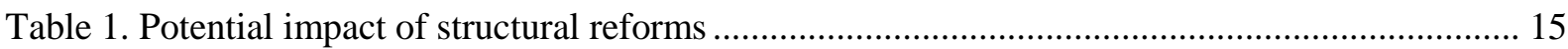

Table 2. Labour market outcomes are below the OECD average ........................................................ 18

Table 3. Costa Rica is reviewing sectors exempt from competition law............................................... 44

Figures

Figure 1. GDP per capita and labour productivity are converging, but remain at low levels ................ 7

Figure 2. Multi-factor productivity growth has picked up .............................................................. 8 
Figure 3. The GDP per capita gap reflects low productivity and employment, but long working

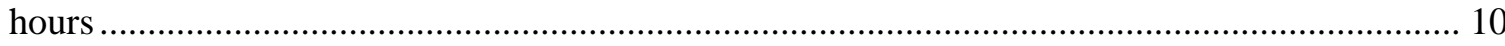

Figure 4. In-kind benefits moderate high market- and disposable-income inequality .......................... 11

Figure 5. Labour market conditions remain a concern....................................................................... 12

Figure 6. Labour market outcomes are particularly poor among disadvantaged groups....................... 13

Figure 7. Female labour market participation lags behind most OECD and Latin American

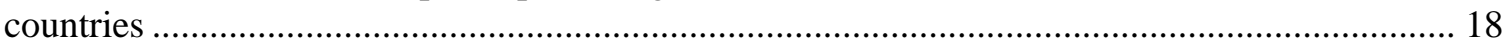

Figure 8. Care responsibilities are a barrier to women's labour market participation.............................. 19

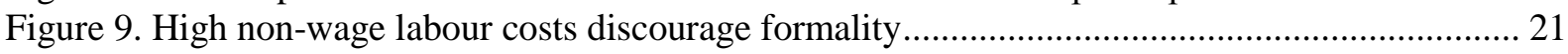

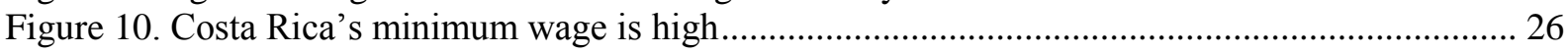

Figure 11. Low outcomes and inequities in education persist despite high levels of spending ............ 30

Figure 12. Socio-economic gaps in tertiary education enrolment are among the largest in Latin

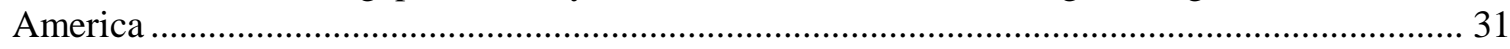

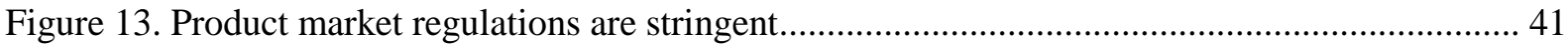

Figure 14. State controls and barriers to entrepreneurship restrict competition................................... 42

Figure 15. Costa Rica is specialising in complex products .................................................................. 49

Figure 16. Knowledge-intensive services are an increasingly important part of the economy ............. 50

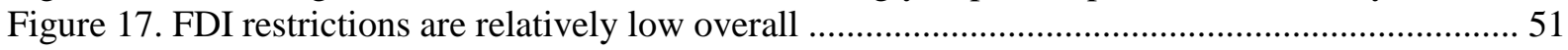

Figure 18. Services trade restrictions are high, particularly in transport and logistics......................... 52

Figure 19. Investment in knowledge-based capital is lagging ............................................................ 53

Figure 20. A large and increasing share of R\&D is financed by the government ................................ 54

Figure 21. Costa Rica is well integrated into GVCs from a backward participation perspective ......... 56

Figure 22. Perceived quality of transport infrastructure is low .......................................................... 58

\section{Boxes}

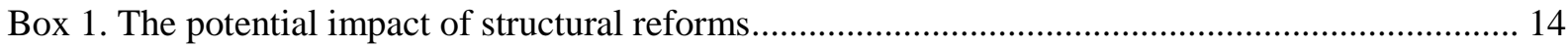

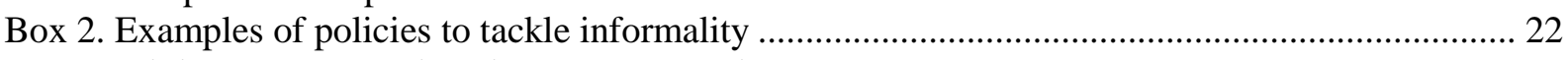

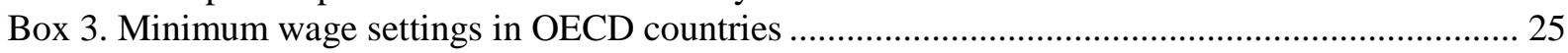

Box 4. Recommendations for structural policies to boost productivity and inclusion .......................... 62 


\title{
Structural policies to boost productivity and inclusion in Costa Rica
}

\author{
By Lisa Meehan ${ }^{1}$
}

While Costa Rica's economic and social achievements have been significant, greater productivity growth and inclusiveness are needed to improve living standards further and distribute the benefits of progress more widely. The recovery in output growth after the global financial crisis was rapid and robust, with GDP growth of above $4 \%$ in most years since 2010. In addition, after many years of sluggish productivity growth, performance has improved since the mid-2000s and is now driving convergence towards the OECD average (Monge-González, 2016; Escobar and Meehan, 2018). Average annual labour productivity growth has picked up from $0.6 \%$ between 1993 and 2005 to $3.7 \%$ between 2006 and 2016, and similarly, multi-factor productivity (MFP) growth has gone from $0.5 \%$ to $2.9 \%$ (Figure 1 and Figure 2). This acceleration has been broad based, with most industries experiencing a structural break towards higher productivity growth (Escobar and Meehan, 2018). However, significant scope for further convergence remains. GDP per capita is 39\% of the OECD average and remains below that of Mexico and Chile (Figure 3). This gap reflects low labour productivity, which stands at 36\% of the OECD average, while labour utilisation is above the OECD average (Figure 1). Furthermore, even at the faster growth rate experienced over the last decade of $3.7 \%$ a year, it will take almost 30 years to reach the current OECD average labour productivity level. Boosting productivity will therefore be key to raising living standards.

Moreover, in order for economic growth to improve the lives of all Costa Ricans, its benefits need to be more widely spread. Inequality is high relative to OECD countries, and in contrast to other Latin American countries, has been increasing (González Pandiella and Gabriel, 2017). This income inequality is tempered by the public provision of health care and education, which has been a key component of Costa Rica's social progress. Indeed, while market and disposable income inequality is similar to that of Peru and Mexico, the distribution of final income is more equal due to these in-kind benefits (Figure 4). However, there is evidence that Costa Ricans are becoming increasing dissatisfied with the quality of these public services and out-of-pocket spending on health care has been increasing (Estado de la Nación, 2016; Estado de la Nación 2017; OECD, 2017a; Araújo and Guichard, 2018).

\footnotetext{
${ }^{1}$ Lisa Meehan is an Economist on the Costa Rica/Mexico desk in the Country Studies Branch of the OECD Economics Department. The author would like to thank Álvaro Pereira, Patrick Lenain, Sónia Araújo, Daniel Blume, Sara Calligaris, Thomas Dannequin, Gernot Hutschenreiter, Manuela Fitzpatrick, Andrea Marin Odio, Iota Nassr, Dirk Pilat and Anna Pons for their valuable comments. The author is also grateful to Damien Azzopardi, Pedro Herrera Gimenez and Alex Linares for statistical assistance and Stephanie Henry for editorial assistance.
} 
This strong economic growth has also failed to translate into positive labour market outcomes. While Costa Rica's labour utilisation (hours worked per capita) is above the OECD average, this reflects working hours among the employed that are longer than all OECD countries, but below-average employment rates (workers as a share of the total population) due to high unemployment and low labour force participation (Figure 3, Panel B; Figure 5, Panels A and B). Indeed, the share of employed workers in the population is lower than all OECD countries except Greece and Turkey (Figure 3; Panel B). Unemployment has remained elevated since the global financial crisis, with much of this increase due to structural change as industries which traditionally absorbed lowskilled labour have grown more slowly than high-skilled manufacturing and service sectors (Banco Central de Costa Rica, 2016; OECD, 2017b; Sandoval et al., 2017). This is reflected in the increase in long-term unemployment - in 2016, $16.7 \%$ of unemployed had been out of work for more than a year compared with $9.8 \%$ in 2012 - which, combined with falling labour market participation rates, suggests that many workers have become discouraged (Estado de la Nación, 2017; Figure 5).

Figure 1. GDP per capita and labour productivity are converging, but remain at low levels

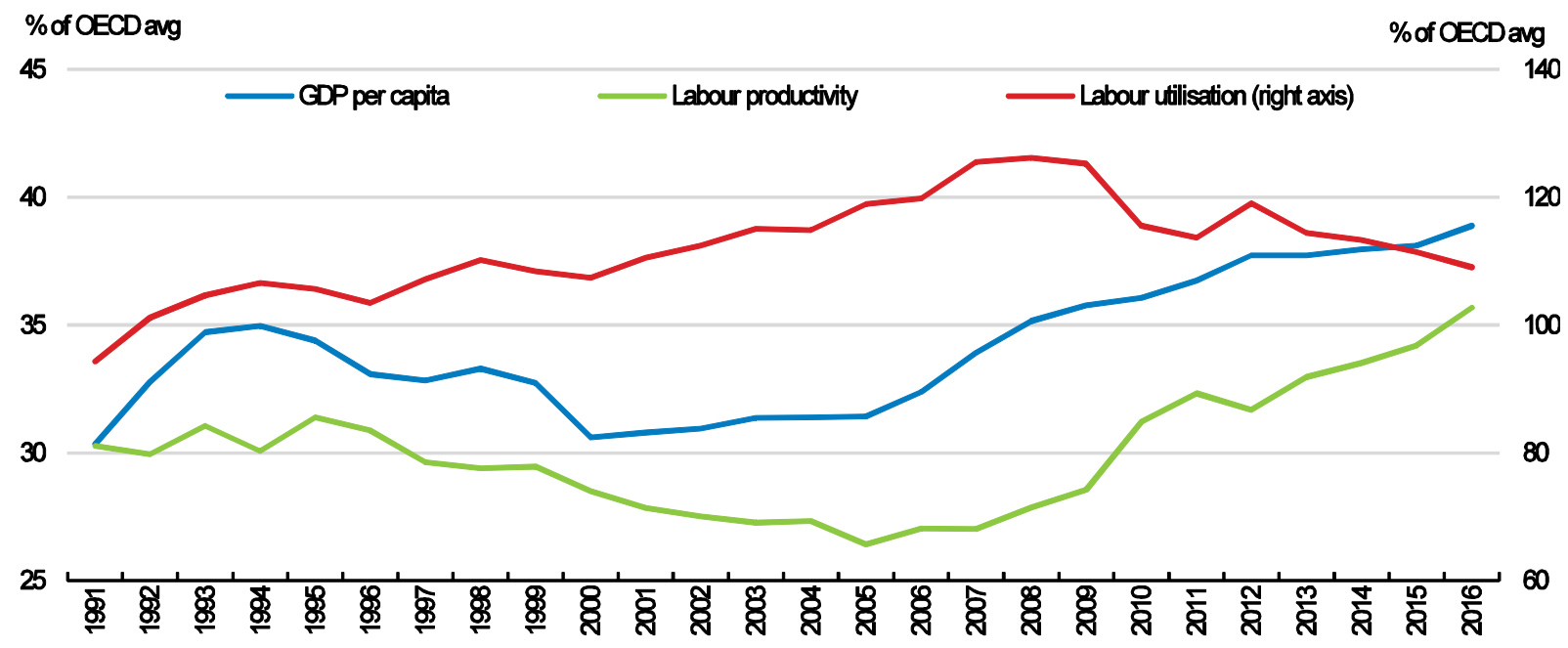

Source: OECD Productivity Database 
Figure 2. Multi-factor productivity growth has picked up

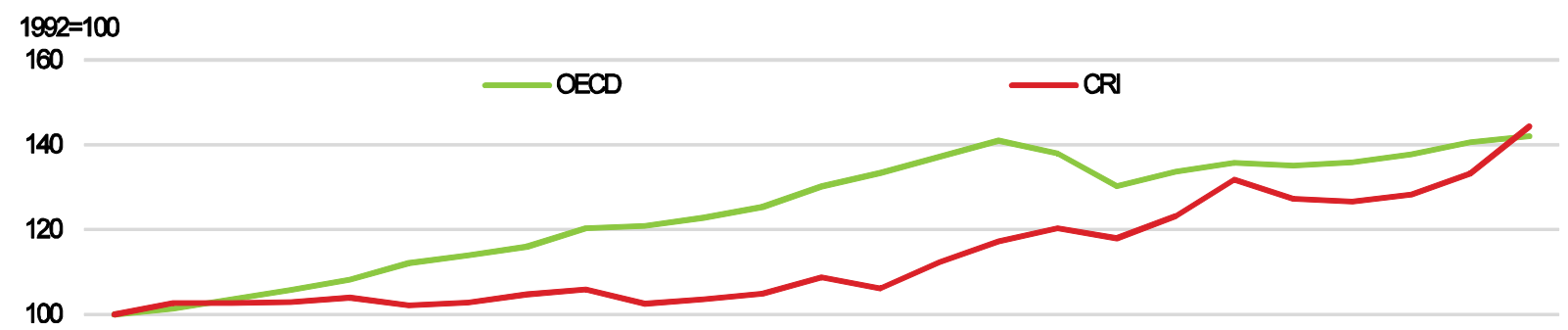

80

60

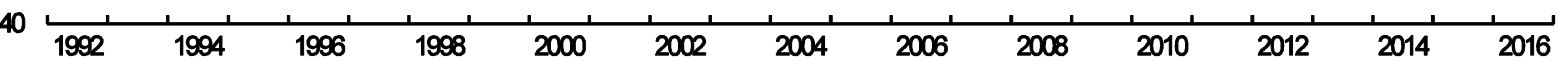

Note: OECD is a simple average of OECD member countries' MFP growth rates Source: OECD Economic Outlook Database.

In addition, while the share of workers in informal jobs is lower than other countries in the region, such as Colombia, Brazil and Mexico, it is high by OECD standards (Figure 5, Panel C). The share of workers holding informal jobs has also increased in the recent past and now remains stubbornly high at around $41 \%$ (Figure 5, Panel B). This contrasts with other Latin American countries where informality has been falling (OECD, 2017b; Box 2). The negative impact of these developments is mostly keenly felt by disadvantaged groups and those who are less equipped to adapt to the higher skill levels demanded by the labour market, including those with low education levels, the young, women and those living in rural areas (Figure 6). This mismatch between the skills demanded and supplied is also evident in the increasing earnings premium for skilled workers, which is further contributing to rising inequality (González Pandiella and Gabriel, 2017).

Structural policy reforms are needed to avoid poverty traps whereby individuals with low skills and poor access to opportunities are confined to low-productivity and low-wage jobs, which in turn reduces aggregate productivity and further worsens inequality (Ferreira et al., 2014; OECD, 2016a). Setting in motion a 'virtuous cycle' will require coordinated and concerted reforms across a range of policy areas that provide win-win opportunities to boost both productivity and inclusion (OECD, 2016a). This paper first discusses policies to boost inclusion that will help individuals fulfil their potential and lay the foundations for stronger future productivity growth, including measures to make labour markets more inclusive and enhance education. It then discusses policies to increase productivity growth and help firms fulfil their potential that will also level the playing field and reduce economic inequalities, including reforms to strengthen competition, promote innovation and address transport infrastructure gaps.

Recognising the twin challenges of boosting productivity and inclusion, Costa Rica has accelerated its structural reform momentum recently, with initiatives to improve policy design across a number of areas. Examples of areas where legislative changes have been made and/or other initiatives are well advanced include an overhaul of the labour laws to improve worker protection that came into force in July 2017, the roll-out of a modernised school curriculum that is due to be completed in 2018, modifications to social security contributions aimed at increasing coverage among target groups of workers and a 
reduction in the number of minimum wage categories. Effectively implementing reforms still poses a significant challenge in some of these areas, particularly given the high degree of institutional fragmentation and lack of coordination, steering and accountability mechanisms across many areas of the public sector (OECD, 2015a; OECD, 2016b; OECD, 2017a; OECD, 2017b; OECD, 2017c; OECD, 2017d; OECD, 2017e; Araújo and Guichard, 2018). For example, greater teacher training is needed to successfully implement the new school curriculum, with half of surveyed teachers unable to explain the difference between the new and old curricula (OECD, 2017c). Other positive initiatives are currently in the planning or consultation stage. Examples include a bill to increase the independence and resources of the competition authority, the development of a bill to unify and streamline the regulatory framework for business insolvency, and the establishment of a national strategy to transition to a formal economy. Greater reform efforts are needed in some important areas, such as shifting the focus of education to outcome targets and strengthening competition. However, many initiatives aimed at adopting the 2016 OECD Economic Assessment recommendations are underway.

The breadth and depth of possible structural policy improvements highlighted in the 2016 Economic Assessment and several recent in-depth OECD policy reviews of Costa Rica also underscores the importance of directing immediate reform efforts to areas that are likely to bring large gains and/or that set the framework conditions necessary to fully realise the benefits of future reforms. Based on available research quantifying the potential gains of reforms (see Box 1) and the experiences of other countries, reforms to reduce labour market informality, improve educational outcomes, strengthen competition and address transport infrastructure gaps are highlighted as important areas. In labour markets and education, priority actions include expanding early childhood education and care, refocusing spending to pre-tertiary education and further progressing towards a simpler minimum wage. To boost productivity, reforms should focus on enhancing competition, including by adopting and implementing the bill reinforcing the powers, independence and funding of the competition authority. Other priorities include restricting the scope for anti-trust exemptions from competition, and reducing burdensome regulation that limits firm entry and exit and business formalisation. 
Figure 3. The GDP per capita gap reflects low productivity and employment, but long working hours

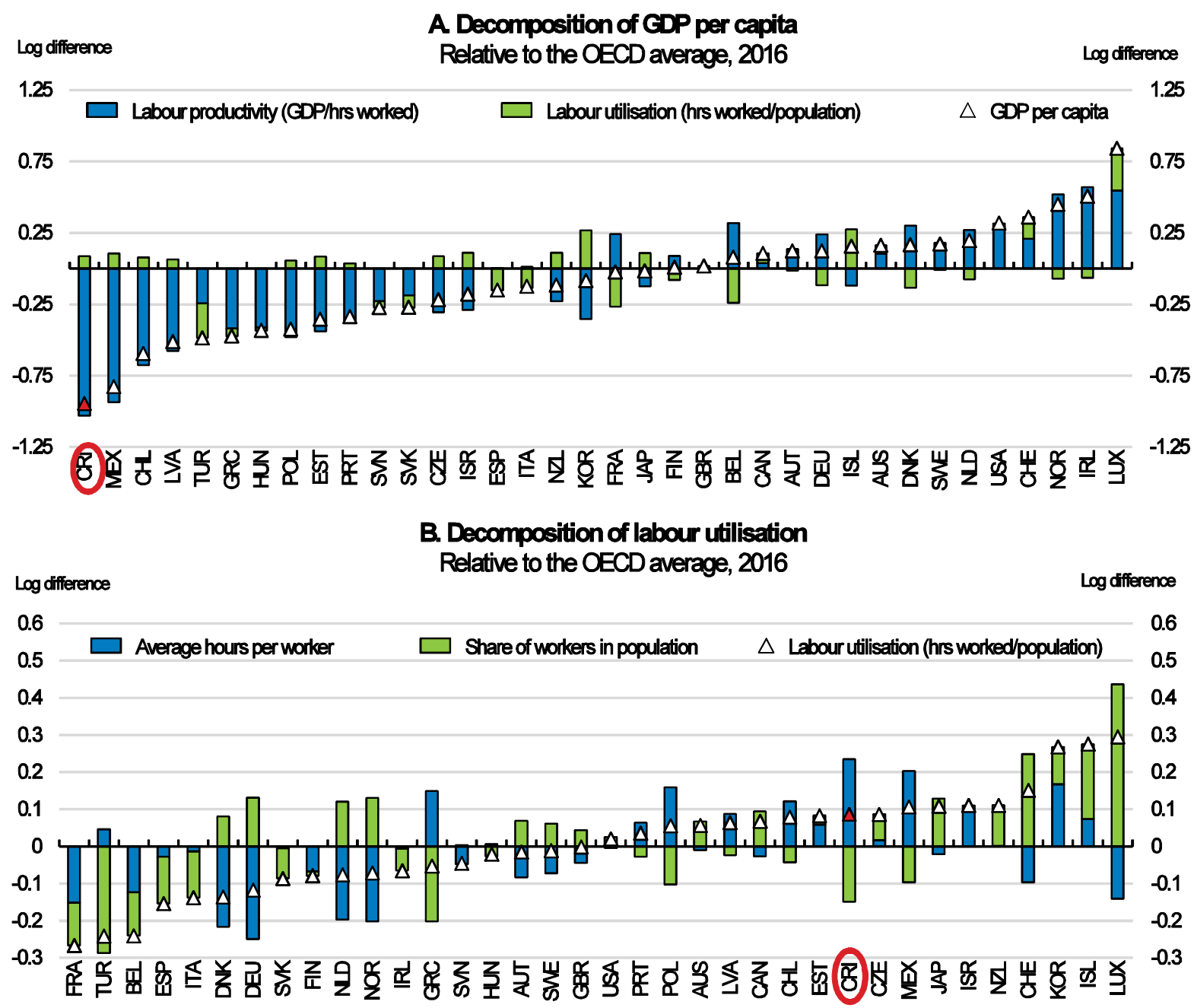

Source: OECD Productivity Database. 
Figure 4. In-kind benefits moderate high market- and disposable-income inequality

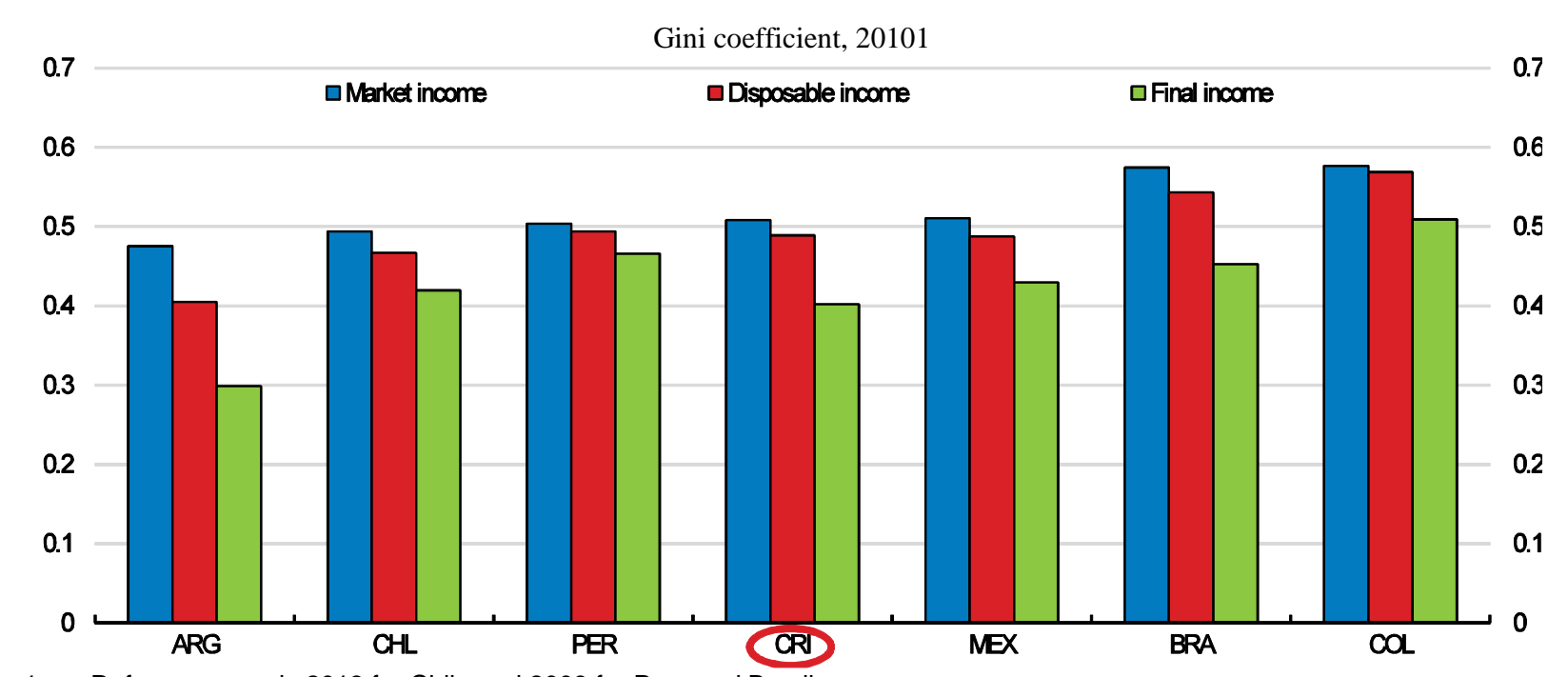

1. Reference year is 2013 for Chile and 2009 for Peru and Brazil. Source: Lustig (2017). 
Figure 5. Labour market conditions remain a concern

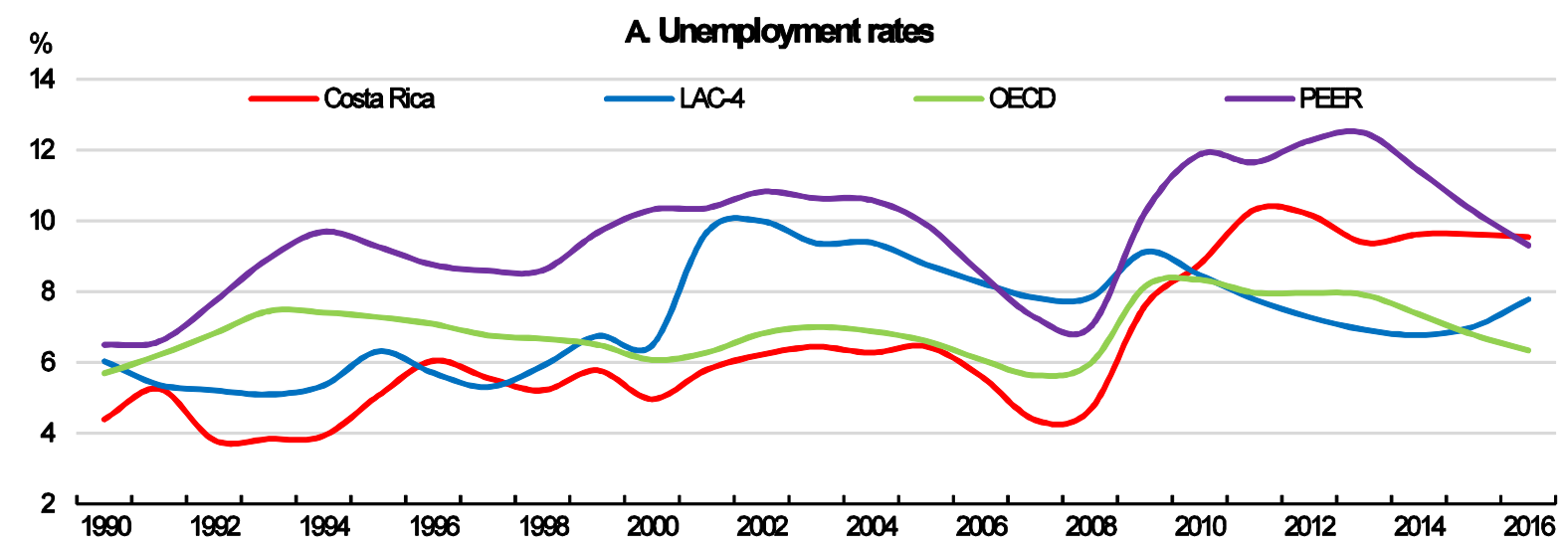

\section{B. Labour force participation and informality rates}

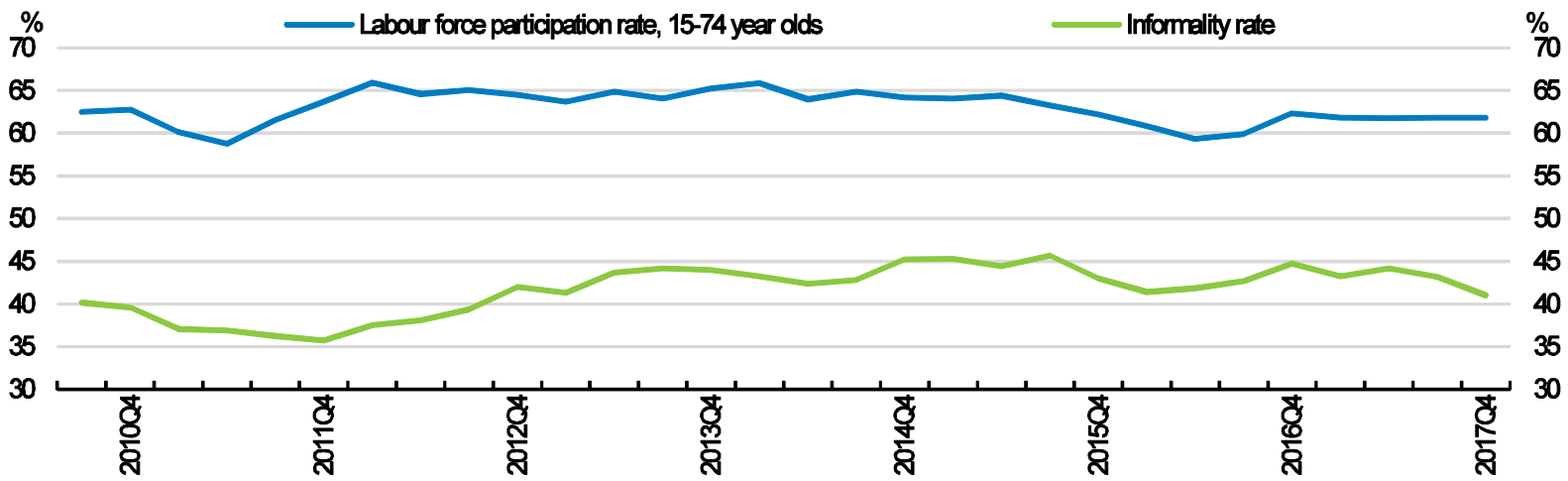

\section{Informality rates for total employed aged 15-64, latest available year}

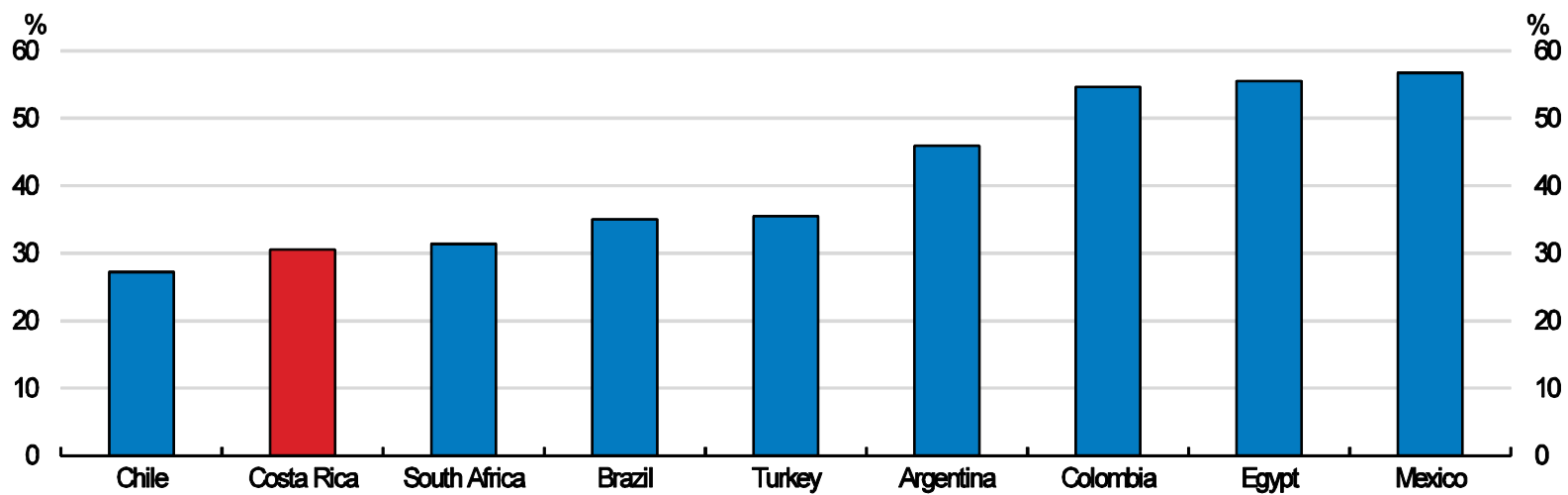

1. Informality is defined to include i) employees who do not pay social security contributions, and ii) self-employed who do not pay social security contributions (Chile, Costa Rica and Turkey), or whose business is not registered (Argentina, Brazil, Colombia, Egypt, Mexico, Peru and South Africa). The informality rate for Costa Rica differs from the official measure of informality from INEC presented in Panel B in order to facilitate cross-country comparisons (see OECD, 2017b).

2. Note: LAC-4 is a simple average of Brazil, Colombia, Chile and Mexico. PEER is the 10 non-Latin American OECD countries with the lowest GDP per capita: Czech Republic, Estonia, Greece, Hungary, Latvia, Poland, Portugal, Slovak Republic, Slovenia and Turkey.

Source: OECD Economic Outlook 102; INEC Encuesta Continua de Empleo; OECD (2017b). 
Figure 6. Labour market outcomes are particularly poor among disadvantaged groups
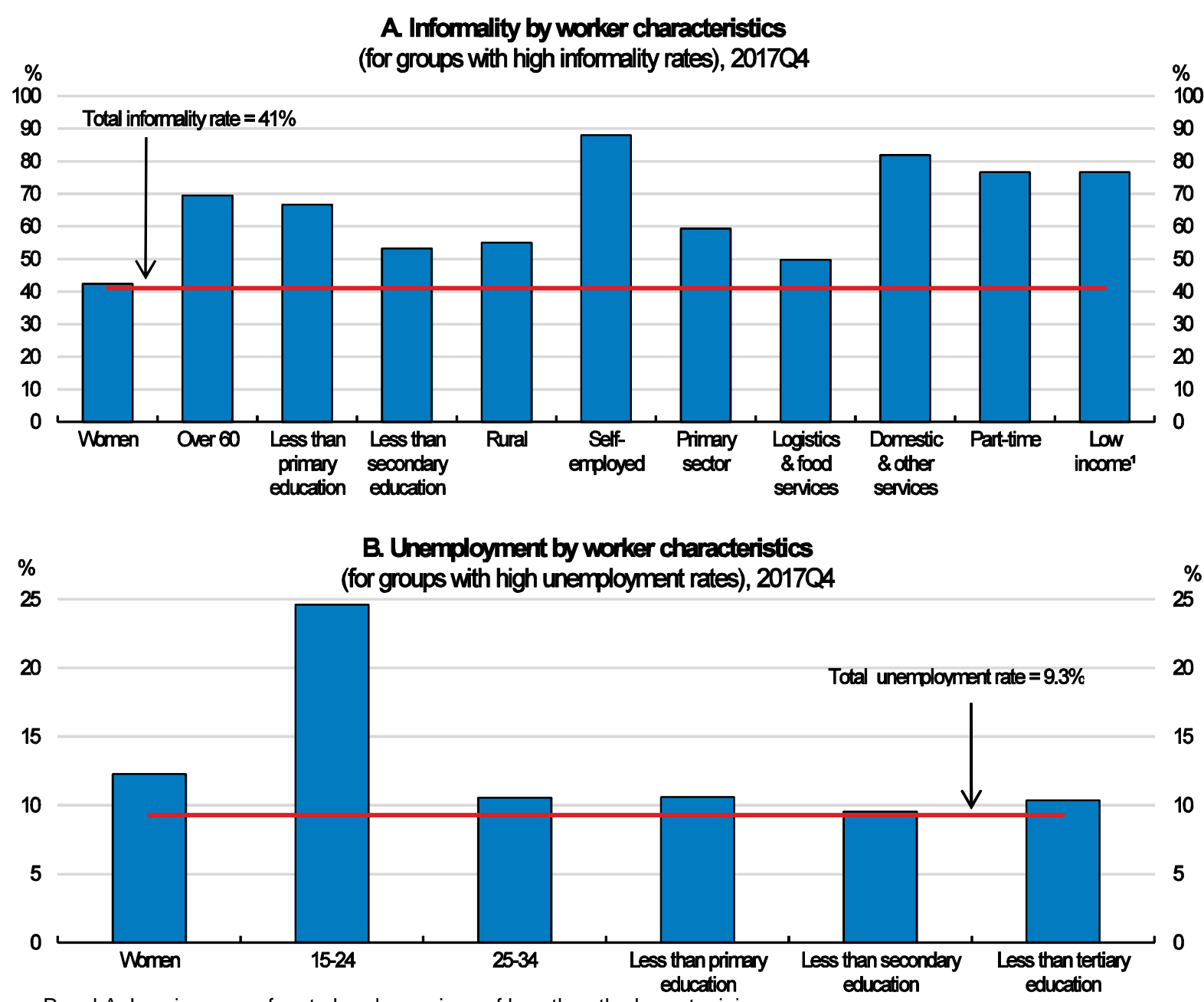

1. Panel A: Low income refers to hourly earnings of less than the lowest minimum wage.

Source: INEC, Encuesta Continua de Empleo. 


\section{Box 1. The potential impact of structural reforms}

The quantification of the impact of structural reforms on GDP provides insights into the potential size of the payoff, which is a useful input into prioritisation decisions. Table 1 summarises relevant estimates of the effects of structural reforms. While differences in measurement and methodology make it difficult to compare across the various reform areas and the effects are not additive, these estimates provide an indication of the sizeable effect that improvements in labour market, education, product market, insolvency and transport infrastructure policies may have.

For example, recent OECD research estimates the effects using simulations based on historical and cross-country relationships between reforms and growth in OECD and non-OECD countries (Égert, 2017). Taken together, the proposed product market regulation (PMR) measures could boost GDP per capita by $5.1 \%$ in the long term. These gains are sizeable despite the fact that even if all of these product market reforms were implemented, the stringency of regulations in Costa Rica would remain significantly above the OECD average, and be at a similar level to Greece or Slovenia and slightly better than Colombia. Reducing the time it takes to resolve corporate insolvency from the current 3 to 2.5 years could boost GDP per capita by $5.4 \%$. However, it is important to note that the magnitude of the insolvency estimate is not directly comparable to the PMR results due to methodological differences. In particular, the PMR estimates are based on average time (within) effects, whereas the insolvency estimate uses cross-country (between) effects. This makes a large difference to the results - for example, using PMR estimates based on cross-country effects would yield much larger estimates, in the range of a $24 \%$ boost to GDP per capita. It should also be noted that improvement measures are often only proxies. For example, increasing the road network is a proxy for the quantity of infrastructure in Lanau (2017), and furthermore, increasing the road network will only bring benefits if investment decisions are based on sound selection and prioritisation of projects via costbenefit analysis.

There are some other important policy areas that have not yet been quantified for Costa Rica, although estimates for other countries provide a general indication of the potential impact of reforms. For example, for Mexico it is estimated that resource misallocation is much higher among informal firms and every peso of capital and labour that is allocated to an informal firm would be worth $28 \%$ more if allocated to a formal firm. While estimates for Costa Rica are not available, this suggests that informality has a large negative impact on aggregate productivity and GDP (Busso et al., 2012). In aggregate, improving resource allocation could increase GDP in Mexico by $125 \%$, with informal firms accounting for 35 percentage points of this gain (IMF, 2017).

Likewise, estimates of skill mismatches for Costa Rica based on the OECD Survey of Adult Skills data are not available. However, eliminating skill mismatches in a country where about a third of workers are either under- or overskilled for their jobs (such as in Italy) could increase productivity levels by $10 \%$ (Adalet McGowan and Andrews, 2015). 
Table 1. Potential impact of structural reforms

\begin{tabular}{|c|c|c|c|}
\hline $\begin{array}{l}\text { Structural } \\
\text { policy area }\end{array}$ & $\begin{array}{l}\text { Description and } \\
\text { magnitude of } \\
\text { improvement }\end{array}$ & $\begin{array}{l}\text { Estimated } \\
\text { impact }\end{array}$ & Source \\
\hline \multicolumn{4}{|c|}{ Inclusive labour markets } \\
\hline $\begin{array}{l}\text { Reduce gender } \\
\text { gaps in labour } \\
\text { market } \\
\text { participation }\end{array}$ & $\begin{array}{l}\text { Eliminate gender gaps in } \\
\text { labour market } \\
\text { participation and } \\
\text { opportunities (i.e. choice } \\
\text { to become an entrepreneur } \\
\text { and choice of job) }\end{array}$ & $\begin{array}{l}\text { Gender gaps } \\
\text { in Costa Rica } \\
\text { result in a } \\
22 \% \text { total } \\
\text { loss in long- } \\
\text { run income }\end{array}$ & $\begin{array}{l}\text { Cuberes and } \\
\text { Teignier } \\
(2016)\end{array}$ \\
\hline \multicolumn{4}{|c|}{ Education and skills } \\
\hline $\begin{array}{l}\text { Improve skill } \\
\text { levels }\end{array}$ & $\begin{array}{l}\text { Achieve universal basic } \\
\text { skills (i.e. universal } \\
\text { secondary school } \\
\text { enrolment for } 15 \text { year olds } \\
\text { and PISA scores of } 420 \text { or } \\
\text { above) }\end{array}$ & $\begin{array}{l}\text { Increase in } \\
\text { GDP growth } \\
\text { of } 0.65 \\
\text { percentage } \\
\text { points a year }\end{array}$ & $\mathrm{OECD}(2015 b)$ \\
\hline \multicolumn{4}{|c|}{ Product market regulation } \\
\hline $\begin{array}{l}\text { Improve the } \\
\text { governance of } \\
\text { state-owned } \\
\text { enterprises } \\
\text { (SOEs) }\end{array}$ & $\begin{array}{l}\text { SOEs no longer have } \\
\text { access to financing that is } \\
\text { not available to private } \\
\text { companies. Establish an } \\
\text { ownership unit within the } \\
\text { Ministry of the Presidency } \\
\text { to manage the } \\
\text { government's equity in } \\
\text { SOEs. }\end{array}$ & $\begin{array}{l}1.1 \% \text { long- } \\
\text { run increase } \\
\text { in GDP per } \\
\text { capita levels }\end{array}$ & $\begin{array}{l}\text { Égert (2017); } \\
\text { Égert and Gal } \\
\quad(2017)\end{array}$ \\
\hline $\begin{array}{l}\text { Streamline the } \\
\text { licences and } \\
\text { permits system }\end{array}$ & $\begin{array}{l}\text { Establish one-stop shops } \\
\text { implemented at the local } \\
\text { level with information } \\
\text { available online. }\end{array}$ & $\begin{array}{l}1.6 \% \text { long- } \\
\text { run increase } \\
\text { in GDP per } \\
\text { capita levels }\end{array}$ & $\begin{array}{l}\text { Égert (2017); } \\
\text { Égert and Gal } \\
(2017)\end{array}$ \\
\hline $\begin{array}{l}\text { Reduce } \\
\text { administrative } \\
\text { barriers for firms }\end{array}$ & $\begin{array}{l}\text { Procedures that are } \\
\text { currently done by the } \\
\text { entrepreneur (e.g. } \\
\text { registering with the social } \\
\text { security agency) are done } \\
\text { by a one-stop shop. The } \\
\text { number of days to register } \\
\text { a business reduces to } 20 \text {, } \\
\text { and the number of bodies } \\
\text { to contact in order to } \\
\text { register falls to } 1 .\end{array}$ & $\begin{array}{l}0.9 \% \text { long- } \\
\text { run increase } \\
\text { in GDP per } \\
\text { capita levels }\end{array}$ & $\begin{array}{l}\text { Égert (2017); } \\
\text { Égert and Gal } \\
(2017)\end{array}$ \\
\hline
\end{tabular}




\begin{tabular}{|c|c|c|c|}
\hline $\begin{array}{l}\text { Remove anti- } \\
\text { trust exemptions }\end{array}$ & $\begin{array}{l}\text { Anti-trust exemptions are } \\
\text { removed. }\end{array}$ & $\begin{array}{l}0.5 \% \text { long- } \\
\text { run increase } \\
\text { in GDP per } \\
\text { capita levels }\end{array}$ & $\begin{array}{l}\text { Égert (2017); } \\
\text { Égert and Gal } \\
(2017)\end{array}$ \\
\hline $\begin{array}{l}\text { Improve trade } \\
\text { facilitation } \\
\text { through better } \\
\text { communication }\end{array}$ & $\begin{array}{l}\text { Regulations are } \\
\text { communicated in an } \\
\text { accessible manner at the } \\
\text { international level. }\end{array}$ & $\begin{array}{l}0.9 \% \text { long- } \\
\text { run increase } \\
\text { in GDP per } \\
\text { capita levels }\end{array}$ & $\begin{array}{l}\text { Égert (2017); } \\
\text { Égert and Gal } \\
(2017)\end{array}$ \\
\hline \multicolumn{4}{|c|}{ World Bank Doing Business } \\
\hline $\begin{array}{l}\text { Improve } \\
\text { insolvency } \\
\text { procedures }^{2}\end{array}$ & $\begin{array}{l}\text { Reduce the time to } \\
\text { insolvency from } 3 \text { years to } \\
2.5 \text { years. }\end{array}$ & $\begin{array}{l}5.4 \% \text { long- } \\
\text { run increase } \\
\text { in GDP per } \\
\text { capita levels }\end{array}$ & $\begin{array}{l}\text { Égert (2017); } \\
\text { Égert and Gal } \\
\quad(2017)\end{array}$ \\
\hline \multicolumn{4}{|c|}{ Transport infrastructure } \\
\hline $\begin{array}{l}\text { Improve road } \\
\text { infrastructure } \\
\text { quality }\end{array}$ & $\begin{array}{l}\text { Increase the quality of } \\
\text { Costa Rica's roads to the } \\
\text { median for Latin } \\
\text { American countries, based } \\
\text { on the World Economic } \\
\text { Forum Global } \\
\text { Competitiveness Report } \\
\text { quality measure. }\end{array}$ & $\begin{array}{l}\text { Increase in } \\
\text { GDP growth } \\
\text { of } 0.14 \\
\text { percentage } \\
\text { points }\end{array}$ & Lanau (2017) \\
\hline $\begin{array}{l}\text { Expand the road } \\
\text { network }\end{array}$ & $\begin{array}{l}1 \% \text { increase in the number } \\
\text { of kilometres of road. }\end{array}$ & $\begin{array}{l}\text { Increase in } \\
\text { GDP growth } \\
\text { of } 0.18 \\
\text { percentage } \\
\text { points }\end{array}$ & Lanau (2017) \\
\hline \multicolumn{4}{|c|}{$\begin{array}{l}\text { The change in GDP per capita is calculated using Equation } 5 \text { of Egert and Gal (2017) and assumes a labour force } \\
\text { to working-age population ratio in } 2013 \text { of } 56.4 \% \text { for Costa Rica. }\end{array}$} \\
\hline $\begin{array}{l}\text { Due to estimation diffe } \\
\text { insolvency measure is } n\end{array}$ & $\mathrm{~s}$, the magnitude of the impa & a & Vorld Bank Doing B \\
\hline
\end{tabular}

\section{Making labour markets more inclusive}

Lifting the quantity and quality of jobs is a priority for achieving inclusive growth in Costa Rica. The share of workers in the Costa Rican population is lower than almost all OECD countries (Figure 3, Panel B). This is despite the fact that, at $66.1 \%$, the share of the population that is of working age (15-64 years old) is similar to the OECD average (66.7\%), reflecting a higher share of children but a lower share of those aged 65 and over in Costa Rica. Thus, there is significant scope to increase the level of labour market activity, particularly among women and young people, and to reduce labour market segmentation by addressing barriers to formalisation.

Costa Rica has a flexible labour market, with employment protection legislation for permanent workers that is less stringent than most OECD countries, and limited differences between the regulations relating to temporary and permanent employees 
(OECD, 2017b). Despite this, there is significant labour market segmentation, which is largely driven by cost differences between formal and informal employment. This high and increasing level of informality is hindering worker mobility, productivity-enhancing resource allocation and workers' access to quality jobs (López-Calva and Lustig, 2010; Busso et al., 2012; Hoeller et al., 2012; Hsieh, 2015; OECD, 2016a; OECD and IDB, 2016). For example, improving resource allocation could increase GDP in Mexico by $125 \%$, with informal firms accounting for 35 percentage points of this gain (IMF, 2017; Box 1). While the estimated gains are likely to be smaller for Costa Rica as its informal sector is smaller than Mexico's (Figure 5, Panel C), these gains are still significant.

The total labour market participation among 15-64 year olds in Costa Rica was 65\% in 2016, which is lower than the OECD average of $71.7 \%$ (Table 2). This lower participation as well as higher unemployment rates are reflected in the employment rate, which was $58.7 \%$, for $15-64$ year olds compared with the OECD average of $67.0 \%$. In addition, despite an increase over time, at $50.4 \%$ in 2016, the participation of workingage women in the labour market is lower than all OECD countries except Mexico and Turkey (Figure 7). In 2016, just $44.3 \%$ of working-age Costa Rican women were in employment compared with 59.4\% across OECD countries. A large gender gap also persists, as the male participation $(79.2 \%)$ and employment rates $(72.8 \%)$ are much higher, and the unemployment rate among men is lower ( $8.1 \%$ versus $12.2 \%$ for women) (Table 2). These disparities exist despite better school performance by girls than boys in Costa Rica, slightly higher levels of education among working-aged women than men, and a gender-wage gap that is lower than in any OECD country $(1.8 \%$ of the male median wage in 2016) (Carrillo et al., 2014; OECD, 2016b; OECD, 2017c). Traditional gender roles remain strong and care responsibilities are one of the main barriers limiting higher participation by women, particularly for low-income women (Figure 8). Overall, many women are not fully using and developing their skills, which not only exacerbates socioeconomic inequalities, but also limits aggregate productivity and income growth (Ruhm and Waldfogel, 2011; Mateo-Diaz and Rodriguez-Chamussy, 2013; Gal and Theising, 2015). It is estimated that the long-run income loss due to gender gaps in labour market participation and opportunities in terms of job and entrepreneurial choices is $22 \%$ in Costa Rica, compared to an average of $15.4 \%$ for OECD countries (Cuberes and Teignier, 2016; Box 1).

Like in many OECD countries, unemployment and inactivity among young workers is high. In 2007, unemployment among those aged 15-24 years old was below the OECD average (10.8\% versus $12.1 \%)$, but has increased significantly and is now above the OECD average (23.1\% versus $12.9 \%$ in 2016). About a quarter of youth aged $18-24$ years old are not in employment, education nor training (NEET) compared with an OECD average of $15.3 \%$, with higher rates among women (33.3\% versus an OECD average of 16.4\%) and those from low-income families (Estado de la Nación, 2016). This is particularly problematic for Costa Rica as its relatively young population means that employment difficulties among youth will be especially detrimental to future skill levels, productivity and social cohesion (Bell and Blanchflower, 2011).

The high unemployment rate, particularly among youth, coupled with skill shortages highlights that the education system is not equipping people with skills that are demanded by the labour market and the tools needed to adapt to structural and technological change. In addition, the difficulties faced by displaced workers in re-integrating into the labour market highlight the need for enhanced active labour market policies and life-long education and training opportunities. 
Table 2. Labour market outcomes are below the OECD average

\begin{tabular}{lllllll}
\hline & $\begin{array}{l}\text { Costa } \\
\text { Rica }\end{array}$ & $\begin{array}{l}\text { OECD } \\
\text { average }\end{array}$ & $\begin{array}{l}\text { Costa } \\
\text { Rica }\end{array}$ & $\begin{array}{l}\text { OECD } \\
\text { average }\end{array}$ & $\begin{array}{l}\text { Costa } \\
\text { Rica }\end{array}$ & $\begin{array}{l}\text { OECD } \\
\text { average }\end{array}$ \\
\hline Total & 58.7 & 67.0 & 65.0 & 71.7 & 9.7 & 6.5 \\
Men & 72.8 & 74.8 & 79.2 & 80.0 & 8.1 & 6.4 \\
Women & 44.3 & 59.4 & 50.4 & 63.6 & 12.2 & 6.6 \\
\hline
\end{tabular}

Note: For the working-aged population (15-64 years)

Source: OECD Labour Force Statistics

Figure 7. Female labour market participation lags behind most OECD and Latin American countries

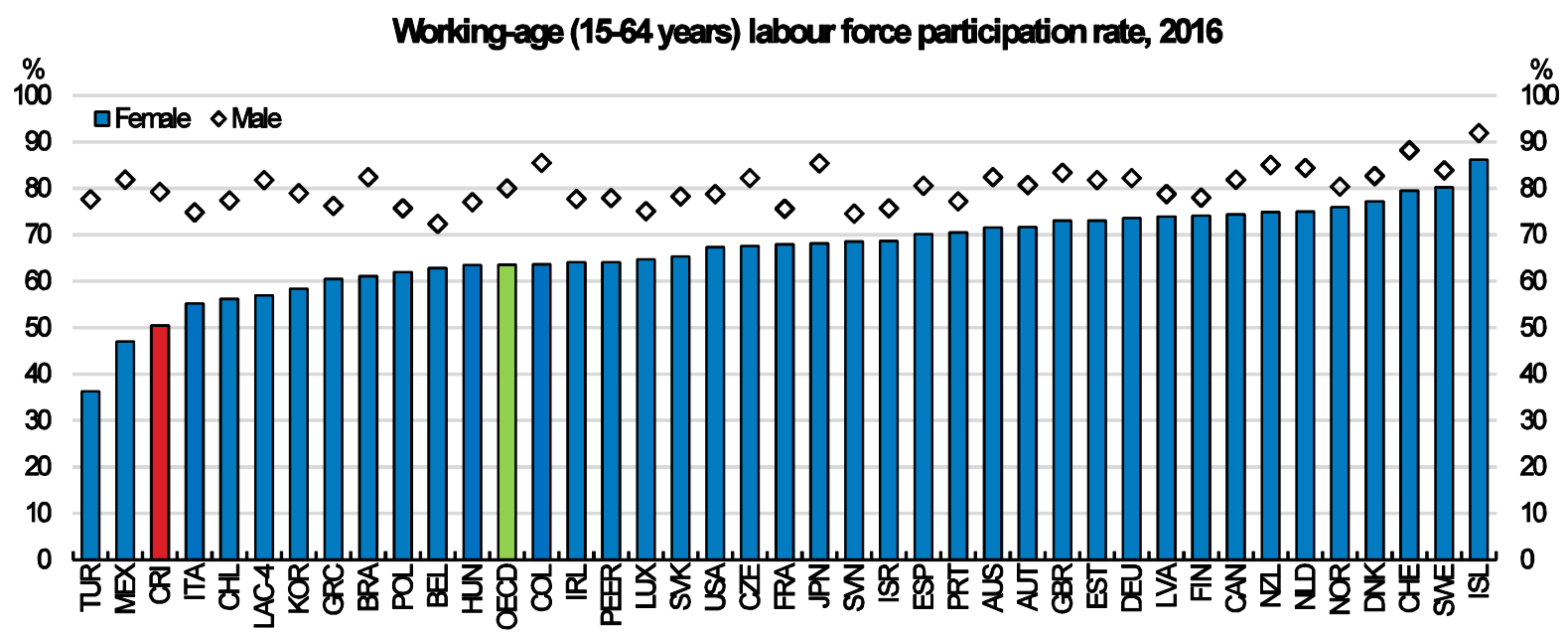

Note: Data for Brazil is 2015. LAC-4 is a simple average of Brazil, Colombia, Chile and Mexico. PEER is a simple average of the 10 non-Latin American OECD countries with the lowest GDP per capita: Czech Republic, Estonia, Greece, Hungary, Latvia, Poland, Portugal, Slovak Republic, Slovenia and Turkey. Source: OECD Labour Force Statistics database. 
Figure 8. Care responsibilities are a barrier to women's labour market participation
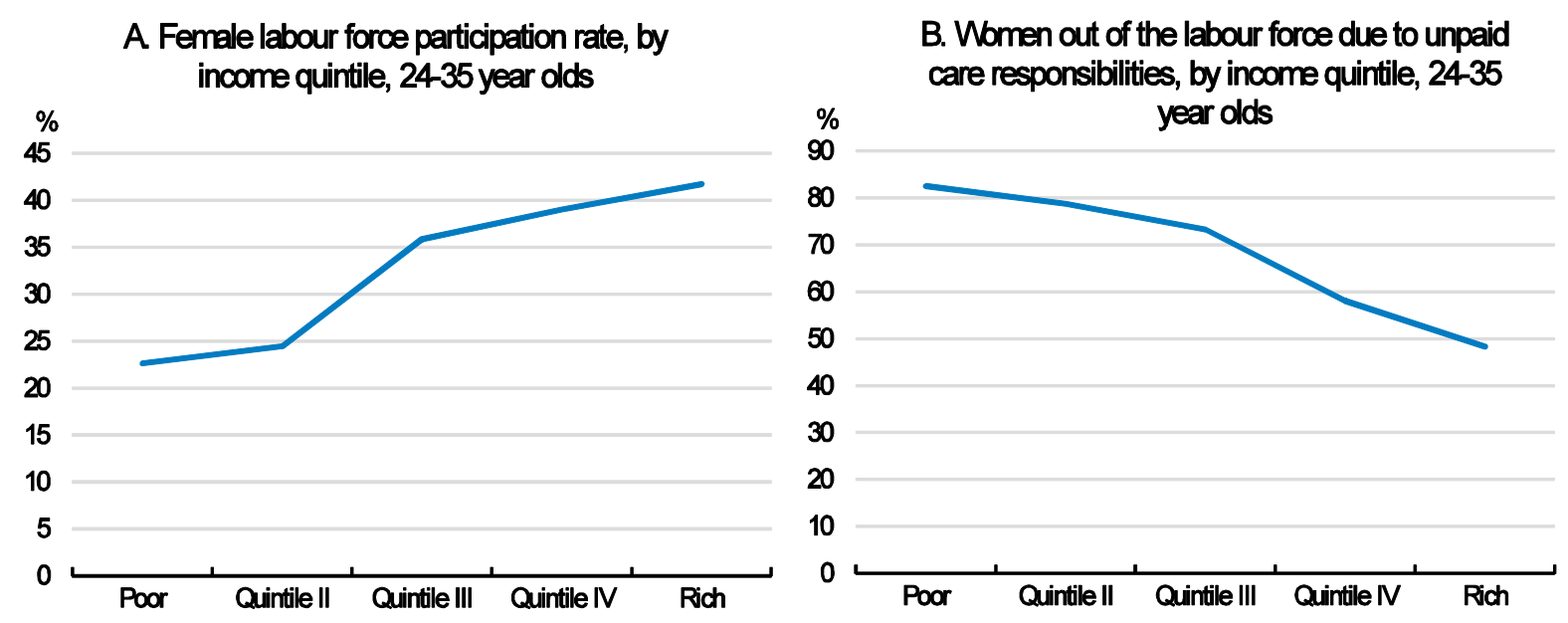

Source: INEC Encuesta Nacional de Hogares 2014.

\section{Encouraging formal employment}

The OECD has recommended the adoption of a comprehensive strategy to tackle informality in Costa Rica, including actions to reduce non-wage labour costs, simplify the minimum wage structure, strengthen enforcement, reduce barriers to entrepreneurship and improve education and training (OECD, 2016b; OECD, 2017b). Other Latin American countries have had relative success with policies aimed at encouraging formalisation (OECD, 2017f; Box 2).

In response, the government launched a National Strategy to Transition to a Formal Economy (Estrategia Nacional para la Transición a la Economía Formal) in February 2018, with the overall goal of reducing informality by 10 percentage points compared with the $2012-2016$ average of $42.6 \%$ by 2025 . Consistent with OECD recommendations, it includes policies aimed at improving education and training, enhancing social protection, reducing regulatory burdens and simplifying tax procedures. The design and implementation will be the responsibility of a tripartite technical council supported by a technical secretariat that will provide semi-annual progress reports and the strategy will be evaluated after 18 months.

While the strategy is still in the early stages, it is a positive step. To address the next challenge of translating the high-level strategy into actionable steps, with clear lines of accountability, timeframes and assessment criteria, the authorities intend to establish detailed actions plans for each of the main areas of the strategy. Incorporating the strategy and associated action plans into the National Development Plan 2018-2022 would solidify it as a priority area going forward. In addition, it will be important for the technical council to have steering mechanisms to influence the work of the numerous relevant agencies that will be involved in the strategy's implementation. The experience of other tripartite councils in Costa Rica is that they have a marginal role in policy making (OECD, 2017b), and to successfully implement the Strategy, the council will need adequate tools to overcome the high degree of public sector fragmentation. The recently created National Council for Trade Facilitation could provide a useful example of a council with both public- and private-sector members that has the authority to make decisions that are binding on the relevant government agencies. An additional challenge 
is that some of the key actions (for example, part of the proposed reduction in social security contributions for new, small businesses, which is discussed below) will require legislative changes, and it is therefore uncertain whether and when these changes will occur.

Reforms to tax and social security payments have been at the centre of relatively successful policy efforts to reduce informality in other Latin American countries, and one of the main features of the Costa Rican strategy involves changes to social security contributions (SSCs) (Box 2). SSCs account for a high share of tax revenues in Costa Rica - 34\% of total tax revenue compared with an average of $16.6 \%$ for LAC-5 and $26.1 \%$ for the OECD - and are a major barrier to formality (Ramírez Alfaro, 2010; ILO, 2014; OECD, 2017b; OECD, 2017g). The total SSC rate in Costa Rica is $36.5 \%$ of gross salary, with 26.33 percentage points levied on the employer and 9.34 percentage points on employees (OECD, 2017g). The large portion payable by employers drives Costa Rica's non-wage labour costs towards the top of the OECD rankings (OECD, 2017b; Figure 9). Unlike OECD countries, the state also pays a small share of SSCs (0.82\% of gross salaries) (OECD, 2017g). In recognition of the need to contain non-wage labour costs, a proposal is currently being considered to make further inflation-adjusted annual state transfers to the contributory pension fund.

Unusually among OECD countries, a significant portion of the SSCs are not used for social security purposes. Out of the total contribution rate, 28 percentage points cover social security (old-age pensions, health care and unemployment insurance). The remaining contributions are used for other purposes, such as financing public banks and anti-poverty programmes. The payment rate is also particularly high relative to earnings for low-income and part-time workers because the minimum base contribution is the same regardless of working hours or earnings, which results in particularly high tax wedges at the bottom of the income distribution and discourages formality (OECD, 2017b; OECD, 2017g; Araújo and Guichard, 2018).

The poor state of public finances does not currently allow for a significant reduction in contribution rates (see Araújo and Guichard, 2018). However, the government is investigating options to increase coverage in selected sectors with high levels of informality. For domestic service workers, the minimum base contribution rate was lowered from July 2017 and a system to account for contributions from multiple employers established. In addition, a pilot scheme for coffee harvesters involving a reduced social security contribution rate of $15 \%$ to cover health insurance during the harvesting season is due to start in 2018. A special scheme for apprentices is also being considered. The Transition Strategy includes plans to implement similar schemes for at least two additional (yet to be identified) groups of workers. 
Figure 9. High non-wage labour costs discourage formality

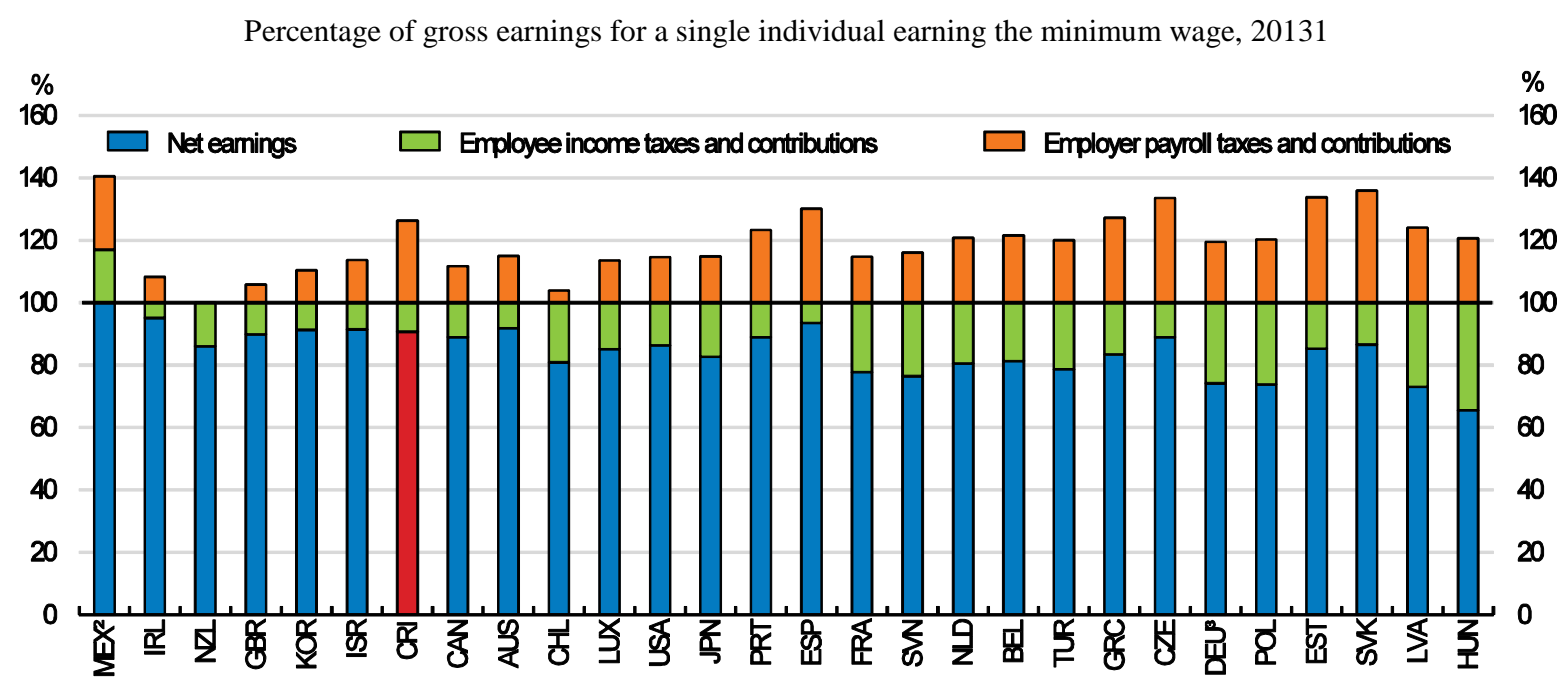

1. Tax burdens are calculated for a full-time worker in a single-person household earning a minimum wage at the standard (adult) rate. Full time refers to usual full-time hours in each country. Employer and employee social contributions also include any mandatory payments to private insurance for health, retirement pensions, etc.

2. Mexican low-wage earnings have negative income taxes because they receive a wage supplement in the form of a tax credit.

3. Minimum wage levels refer to 2015 for Germany.

Note: Countries are ranked in ascending order of the tax wedge.

Source: OECD (2017b).

The government has also proposed lowering the employer contribution rate for new, small businesses for the first four years of operation from approximately $25 \%$ of gross payroll to between $13.33 \%$ and $15.33 \%$. It is expected that an agreement will be reached with the Costa Rican Social Security Agency (Caja Costarricense de Seguro, CCSS) in 2018 to allow the employer contributions to be reduced to between $18.83 \%$ and $20.83 \%$. Furthermore, a proposed bill to reduce the rate by an additional 5.05 percentage points was presented to the Legislative Assembly in November 2015 (Bill 19.805). Evidence from other countries suggests that this scheme could contribute to increased formalisation and the proposal appears to be well designed (European Commission and OECD, 2015; OECD, 2017b; OECD, 2017f). For example, limiting the reduced rates to four years should minimise the fiscal impact and mitigate the risk that this size-contingent policy will act as a disincentive to firm growth (Braguinsky et al., 2011; Garicano et al., 2016). However, it will be important to consider the costs and benefits, ensuring that the policy is indeed contributing to formalisation, that the fiscal consequences are manageable and that there are no major unintended consequences. There are also plans to complement these measures with simplified tax procedures, including the integration of tax and social security payment systems. At this stage, it is unknown whether these changes will proceed and if they do, when they will occur. 


\section{Box 2. Examples of policies to tackle informality}

Informality has decreased in several Latin American countries due to a combination of economic growth and specific policy interventions. For example, evidence suggests that policies to reduce the costs of formal employment in Brazil contributed to reducing the informality rate from over $60 \%$ in 2000 to under $50 \%$ in recent years (Filho and Veloso, 2016; OECD, 2017f). In particular, the 1996 SIMPLES law, which introduced an integrated tax and contribution payment system for micro and small enterprises, facilitated business registration and lowered the tax rate for microenterprises, contributed to the formalisation of nearly half a million microenterprises over five years. A more recent 2008 law aimed at sole-proprietor firms also reduced social security contributions and facilitated an increase in formalisation among the self-employed, although this appears to have had some perverse effects whereby firms have substituted regular employees for self-employed providers. Stricter enforcement mechanisms, including a performance pay system for inspectors, have also helped (OECD, 2013; OECD, 2017f).

In Mexico, two schemes were introduced in 2014 to provide incentives for small businesses to formalise and involve reduced tax and social security obligations for the first ten years of operation. The measures also included incentives to help new formal firms expand through access to government-backed financing and training and a series of electronic tools to simplify tax compliance. Evidence suggests that this has induced 1.5 million informal firms to join the tax system. In addition, a comprehensive labour reform law in 2012 included initiatives to stimulate formal employment by reducing the uncertainty and costs for businesses, for instance, by limiting the cost of terminating employees (OECD, 2015c; OECD 2017f).

Colombia's 2013 tax reform reduced employer payroll contributions by 13.5 percent points, which is estimated to have led to the creation of 213000 formal jobs in the short run and reduced the informality rate by between 1.2 and 2.2 percentage points (Fernández and Villar, 2016; Morales and Medina, 2017; OECD, 2017h; OECD, 2017i).

Shifting the tax mix away from SSCs and towards less distortionary sources, including personal income, corporate and value-added taxes, would be a more far-reaching strategy to reduce barriers to formality. However, changes should be contingent on stabilising the fiscal situation since even a change which is revenue-neutral in principle would entail a higher level of uncertainty in the short run.

As part of this shift, the OECD has also recommended that contributions be used exclusively for social security purposes, with the funding for other institutions and programmes gradually moved to sources that are more progressive and/or are less distortionary (OECD, 2016b; OECD, 2017b). Further consideration could be given to modifying the minimum contribution rate for all workers, particularly if the scheme for domestic service workers is successful. For example, the minimum base contribution rate could vary with working hours or contributions could be proportional to part-time 
incomes (OECD, 2017b). These changes will be particularly important given the changing nature of work that is occurring globally, including increases in part-time, casual and multi-employer workers. In addition, workers must currently contribute for at least 15 years to receive a reduced pension or 25 years to receive a full pension, which discourages workers who are unlikely to reach 15 years of contributions from becoming formal. The minimum years to qualify for a pension could be reduced or eliminated and to avoid very low pension amounts, the non-contributory benefit could be progressively withdrawn as the contributory pension income increases (OECD, 2017b).

Additional measures that will also encourage formality are discussed below, including: improving education and training, imposing stricter enforcement, making it easier to register a business, reducing business compliance costs and simplifying the minimum wage.

\section{Simplifying the minimum wage}

The minimum wage in Costa Rica is set by the tripartite National Salary Council (Consejo Nacional de Salarios, CNS) and varies by skill, occupation and educational attainment. The number of minimum wage categories has decreased significantly over time, from 520 in 1987 to 23 currently. The most recent reduction from 25 to 23 categories came into effect in January 2018. In addition, market studies are currently underway to investigate options to further reduce the number of categories, with the intention of gradually moving to 10 categories by the end of 2019 . However, given that the main goal of minimum wages is to reduce poverty among workers with the weakest bargaining power, differentiating on the basis of occupation and skill levels is unusual. While minimum wage practices across OECD countries vary, in general, most countries have a single statutory minimum wage, or a minimum wage that differs by age group (to recognise that the young are generally less experienced so the minimum wage is a greater hurdle to employment) and/or by region (to account for differences in living costs and local labour market conditions) (Box 3). In addition, the minimum wage for unskilled workers amounts to $70 \%$ of the median full-time wage in Costa Rica, which is higher than all OECD countries except Turkey (Figure 10).

The complex structure of the minimum wage in Costa Rica imposes a heavy administrative burden on firms and contributes to the low levels of compliance. About a third of workers are paid below the relevant minimum wage and about a quarter of workers below the lowest minimum wage (Estado de la Nación 2014; OECD, 2017b). Furthermore, those earning less than the minimum wage are disproportionately young, part-time workers, workers in rural areas, immigrants and workers in agriculture, construction and domestic service sectors (OECD, 2017b). As a result, the current minimum wage structure is not very effective at protecting disadvantaged workers. Moreover, minimum wages can hinder formal employment, particularly among lowincome workers, if the floor is set at a high level, as is the case in Costa Rica (Box 3). For Costa Rica, it is estimated that a $10 \%$ increase in the minimum wage reduces formal employment by about $1 \%$ and working hours by $6 \%$ (Gindling and Terrell, 2007). This highlights the existence of trade-offs between protecting those in relatively stable formal sector jobs and alleviating poverty among the most vulnerable workers.

There are also trade-offs involved in differentiating the minimum wage categories on the basis of occupation, skill and qualification levels. The goal of this system is to encourage people to acquire skills. However, this is unlikely to be necessary as the high and increasing skills premium in Costa Rica signals that the market already rewards skills 
(González Pandiella and Gabriel, 2017). Moreover, the potential effect on skills acquisition is likely to be outweighed by the cost of discouraging formality and limiting worker mobility.

While current efforts to reduce the number of categories are welcome, it is recommended that Costa Rica moves to a small number of minimum wages that differ by age group and/or location and that are set at a more modest level. Differentiating on this basis should be informed by analysis of regional economic conditions and the impact of the minimum wage on formal employment opportunities and education decisions of young people. But, for example, it could involve a higher minimum wage in San José to account for higher living costs and a lower rate for young workers to recognise that the minimum wage is a greater hurdle to employment for those with less experience. This should also be accompanied by stronger enforcement (discussed below). In addition, minimum wage reforms could be complemented with measures to increase the social dialogue given the strong reliance on minimum wage provisions in Costa Rica and the current marginal role of tripartite bodies in policy making. For example, the 2003 proposal to create an Economic and Social Council could be re-visited (OECD, 2017b). 


\section{Box 3. Minimum wage settings in OECD countries}

The primary goal of minimum wages is to reduce poverty by improving the situation of workers with the least bargaining power in the labour market. Most OECD countries have statutory minimum wages and in the few (mainly Nordic) countries that do not have a statutory minimum, a large part of the workforce is covered by sector-level collective agreements which include wage floors. However, the level of the minimum wage, the institutional frameworks for setting minimum wages, the share of workers who earn the minimum wage, and the level of compliance vary across countries. Moreover, in some countries minimum wages are used in conjunction with collective wage bargaining, while in others, such as Costa Rica, they are the main institutional framework to increase the wage bargaining power of the most vulnerable workers.

While the practices across countries varies markedly, OECD (2015d) identifies some key policy principles for minimum wages:

1. Improve coverage of and compliance with minimum wage legislation, especially in countries where collective bargaining is weak or declining.

2. Ensure that minimum wages are revised regularly, based on accurate, upto-date and impartial information and advice that carefully considers current labour market conditions and the views of social partners.

3. Where necessary, allow minimum wages to vary by age group (to reflect differences in productivity or employment barriers) and/or by region (to reflect differences in economic conditions) - bearing in mind that simple minimum wage systems are most likely to achieve high compliance.

4. Make minimum wages pay while avoiding that they price low-skilled workers out of jobs, by carefully considering their interactions with the tax-benefit system.

5. Use minimum wages as a tool to raise wages at the bottom of the wage ladder, but accompany them with other tax and benefit measures to effectively fight poverty in and out of work.

There is ongoing debate about the impact of the minimum wage on employment. Overall, empirical evidence suggests that the negative impact of minimum wage increases on employment tend to be small, but the effects are greater for more vulnerable groups such as the young or the long-term unemployed, or if the starting level of the minimum wage is high (Broecke et al., 2017). For emerging economies, the evidence suggests that minimum wages have only a small negative effect on employment and informality, but in countries where minimum wages are set at a high level, negative employment effects are more evident (ILO, 2013; Broecke et al., 2017). Country specific analysis for Costa Rica suggests that a $10 \%$ increase in the real value of the minimum wage reduces formal privatesector employment by about $1 \%$ and working hours by $6 \%$ (Gindling and Terrell, 2007). Since labour market conditions are less favourable than when this analysis was undertaken, it is also possible that the effect is now larger. Moreover, despite the multiple minimum wages in Costa Rica, the largest impact on wages and employment of formal workers is in the lower end of the distribution (Gindling 
and Terrell, 2007). This suggests that there are important trade-offs between supporting those in relatively stable formal-sector jobs and alleviating poverty among struggling working families (OECD, 2017b).

In setting minimum wage levels, there is also often a trade-off between achieving simplicity (which encourages compliance) and allowing minimum wages to vary by region and/or sub-groups. Around half of OECD countries have lower minimum wages for youth, which can be justified on the grounds that labour market entrants typically have lower productivity than more experienced workers, and that this can help facilitate the transition of young people into the workforce. Regional differences to reflect variation in economic conditions are also fairly common. Some countries also have lower rates for apprentices and workers with disabilities. A few countries also differentiate the minimum by sector/occupation or level of seniority, but this is rare (OECD, 2015d).

Figure 10. Costa Rica's minimum wage is high

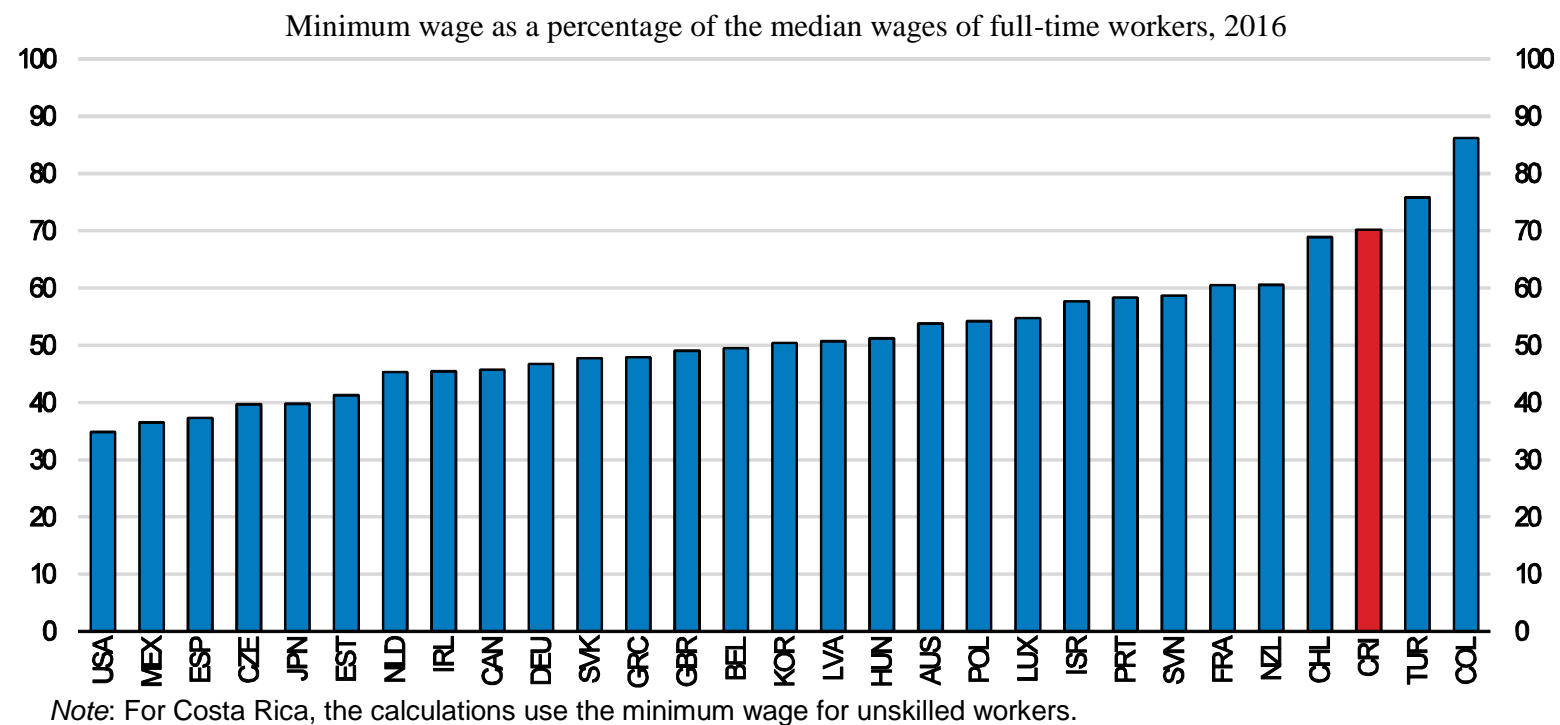

Note: For Costa Rica, the calculations use the minimum wage for unskilled workers.

Source: OECD Labour Force Statistics database.

\section{Strengthening the enforcement of labour regulations}

Tackling high informality and increasing minimum wage compliance hinges upon the ability to monitor, investigate and sanction breaches. The OECD has highlighted the need to strengthen labour inspection services in Costa Rica as inspectors lack basic resources and sparse information means that they are often limited to large firms (OECD, 2017b).

To address these issues, Costa Rica has made a number of changes to labour inspections and further improvements are planned. In 2016, the National Inspection Directorate (Dirección Nacional de Inspección del Trabajo, DNI) changed its inspection approach, granting inspectors more scope to make qualitative assessments, focussing on serious infractions, and making better use of information to target workplace inspections. In addition, the DNI's budget was increased by $20 \%$ and its staff numbers by $40 \%$, resulting 
in a significant increase in the number of workers covered by inspections (from about 175700 in 2014 and 146100 in 2015 to about 200600 in 2016). However, it is not clear whether this has resulted in a greater number of breaches being identified, nor if it has increased the deterrent effect. The National Strategy to Transition to a Formal Economy includes additional actions to run at least one information campaign about employers' labour regulation obligations and plans to formulate a proposal to further improve the resourcing of the DNI.

An additional issue is that once violations of labour market regulations are referred to the labour tribunals, the process can be costly and time consuming, which discourages individuals from reporting breaches (Gindling and Trejos, 2010; OECD 2017b). The recent Labour Procedural Reform Law (Law 9343), which came into force in July 2017, aims to expedite the judicial process and reduce the cost for individuals by requiring decisions to be provided within six months, simplifying the structure of labour tribunals, creating Alternative Dispute Resolution Units throughout the country to provide arbitration services, and offering targeted legal aid. The current proposal to grant labour inspectors the right to impose sanctions directly on employers without going through the labour courts would also help accelerate the process and increase the deterrent effects (Bill 19.130). Going forward, the authorities should ensure that penalties imposed for breaches of labour regulations are high enough to act as a deterrent (OECD, 2016b).

\section{Facilitating the labour market and social integration of immigrants}

Unlike other countries in Central America, Costa Rica has net immigration, with immigrants representing about $11 \%$ of the adult population (OECD, 2017b). Most migrants come from Nicaragua, are of working age and have lower average education levels than the native population. Migrants are over-represented in low-skilled occupations and sectors with high rates of informality, such as construction, domestic services, hospitality and food services and agriculture (OECD, 2017b).

The 2010 Migration Law (Law 8764) and the subsequent Comprehensive Migration Policy provide a solid framework for migration, but implementation challenges remain. Take-up of provisions for immigrants with irregular status to acquire legal residence has been lower than expected. Immigrants wishing to acquire legal status must leave the country, pay a fine at the border and remain outside the country for a time period equivalent to the amount of time they spent irregularly in Costa Rica. However, these requirements were lifted until the end of 2017 for workers in agriculture, construction and domestic services who were able to acquire a work permit upon proof of their employment contract. This low take-up rate reflects high rates of informality preventing irregular migrants from providing formal employment contracts, migrants being deterred by the requirement to leave the country, long processing times and high application fees. Efforts are currently underway to reduce processing times, for example, work on a new IT system is expected to begin in 2018. This new system will also include linkages between relevant government services offered to migrants, which should improve low coverage compared with the native-born population for programmes such as conditional cash transfers to encourage participation in education (OECD/FUNDEVI, 2017). Since $60 \%$ of coffee pickers are immigrants, mainly from Nicaragua and Panama, the special health insurance scheme described above that is due to begin in the 2018 harvest season will also contribute to the integration and well-being of immigrants. However, if the priority of regularisation is to identify those in the country and ensure that they are protected from exploitation, then the OECD has recommended that a one-off 
regularisation be considered without the requirement of a formal employment contract (OECD, 2017b).

Going forward, migration policy could be more responsive to labour market needs. While the Migration Law is comprehensive and views migration as a driver of development, it lacks a strategic vision. Regular analysis of labour market supply and demand should be undertaken to better inform migration policy, and measures to attract skilled migrants in areas where there are labour shortages should be investigated (OECD, 2017b).

\section{Enhancing the quality and efficiency of the education system}

Providing quality education for all is a powerful lever for boosting inclusiveness and productivity (OECD, 2012a). Costa Rica has a strong commitment to education and government spending as a percentage of GDP is higher than almost all OECD countries and has increased significantly, from 5\% of GDP in 2006 to $7.9 \%$ in 2017 (OECD, 2017c; Figure 11, Panel A). However, this high level of spending has not translated into strong outcomes. Although enrolment rates have increased across the board, they remain below the OECD average in all areas except primary education (OECD, 2017c). More than half of young people aged 25-34 have no secondary school qualification, compared with the OECD average of $17 \%$. Grade repetition and drop-out rates have decreased in recent years, but remain elevated. By the age of 15, nearly a third of Costa Ricans have repeated at least one grade and 30\% have dropped out of school (OECD, 2017c). About a third of those who remain in school lack core competencies, with Costa Rica's 15-yearolds performing around two years below their OECD peers according to the Programme for International Student Assessment (PISA) (Figure 11, Panel B).

Costa Rica could achieve better results with the resources it invests. For example, Croatia has a comparable level of GDP per capita and spends a similar amount per student, but by age 15, Croatian students are the equivalent of 1.5 school years ahead of those in Costa Rica. In addition, rapidly developing Latin American countries, such as Peru, have succeeded in simultaneously enrolling more children and improving average learning outcomes (OECD, 2017c). Moreover, outcomes have not increased in line with spending (Jiménez, 2014). For example, a significant portion (60\%) of the rapid increase in spending in the last decade has been due to increases in the wage bill, but there is no evidence that the quality of teaching has improved as a result (OECD, 2017c). At the same time, there is a widespread and acute shortage of textbooks and other learning materials. About $38 \%$ of students are in schools with a shortage of educational materials, which is one of the largest proportions among PISA-participating countries (OECD, 2017c).

In addition, education inequalities remain large. Children from poor families with low levels of parental education, those living outside the capital, or belonging to an indigenous or migrant group are less likely enrol in education at all levels and have lower educational outcomes (OECD, 2017c). PISA results are more strongly influenced by socio-economic status than in most OECD countries (Figure 11, Panel C). This inequality manifests itself most strongly at higher levels of education. Only 3.8\% of young Costa Ricans from the lowest income quintile enrol in tertiary education compared with 57.8\% of those from the wealthiest quintile, one of the largest differences in the Latin American region (Figure 12).

The allocation of funds raises efficiency and equity issues. Giving priority to the formative years helps overcome differences in family background and provides children 
with the foundational skills needed to achieve in later years. While countries need a high quality well-resourced tertiary education system, public expenditure on tertiary education tends to be regressive (OECD, 2007). In Costa Rica, investment in basic education is relatively low, with cumulative spending by the age of 15 around half of the OECD average. While spending per student on preschool education (5 and 6 year olds) has increased, it remains below that of other emerging economies in Latin America and is just one-third of the average OECD expenditure (OECD, 2017c). In contrast, public spending per tertiary student is one of the highest among OECD and Latin American countries (OECD, 2017c). Moreover, spending on primary education has been increasing at a fast rate, accounting for $35 \%$ of additional expenditure, yet demographic trends mean that primary school enrolments have been decreasing while there are growing pressures at the secondary level.

Targeting resources towards the most disadvantaged students also improves efficiency and equity (OECD, 2007). Costa Rica has a number of positive initiatives in this area, including a range of programmes to promote access to school by providing meals, transport, scholarships and conditional cash transfers through the Avancemos and Bridge to Development (Puente al Desarrollo) schemes. In addition, the Yo me Apunto programme was launched in 2015 and is aimed at disadvantaged students at risk of leaving education (discussed below). However, greater advances in this area could be made through more systematic targeting. For example, unlike in many OECD countries, there are no systematic mechanisms to redistribute resources to disadvantaged schools to ensure that at-risk students receive the necessary support (OECD, 2017c). 
Figure 11. Low outcomes and inequities in education persist despite high levels of spending

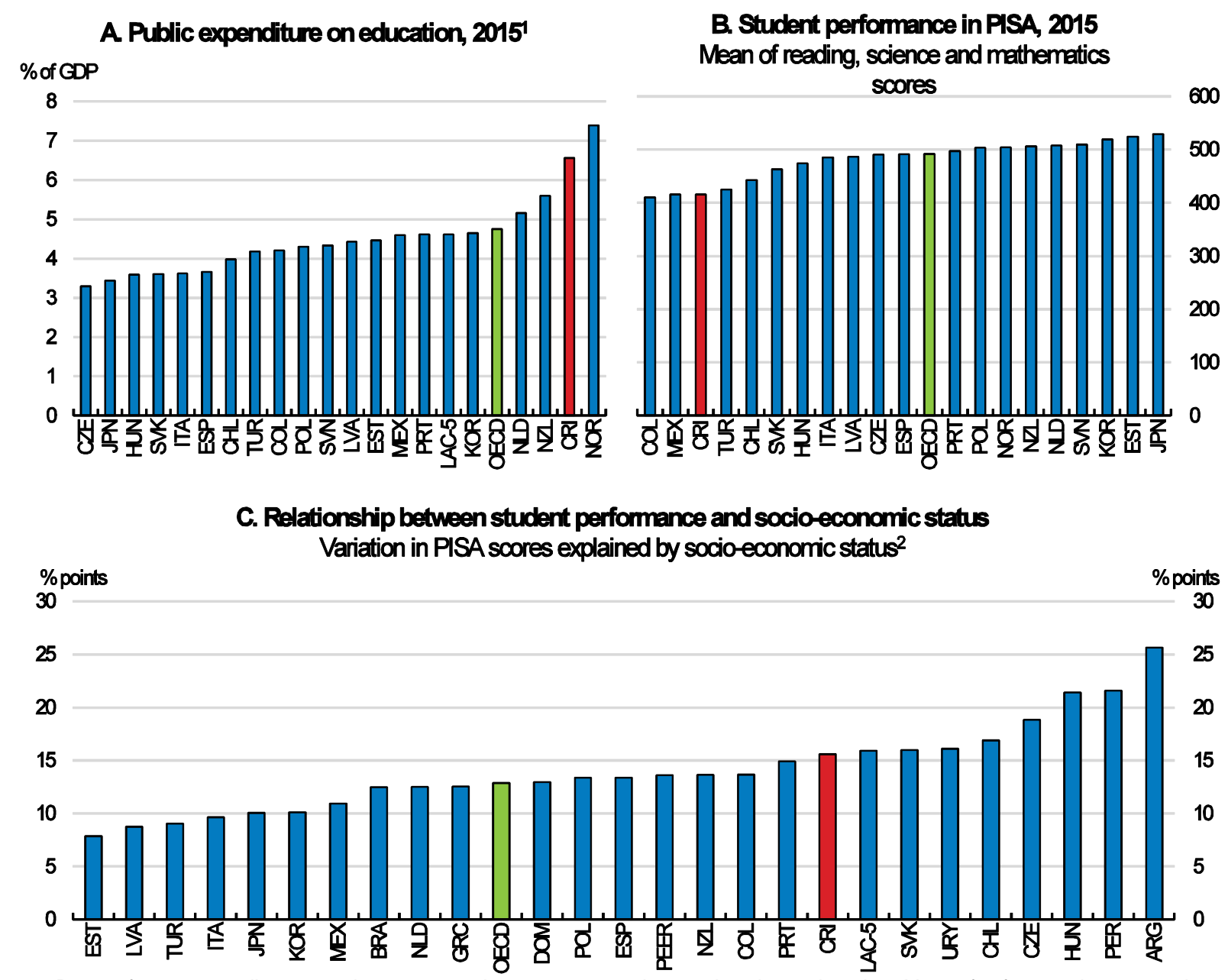

1. Data refer to expenditure on primary, secondary, post-secondary and tertiary education. Year of reference is 2015 or latest available year.

2. Measured as the average change in PISA scores associated with a one-unit change of the PISA index of economic, social and cultural status.

Note: OECD is a simple average of OECD member countries. LAC-5 is a simple average of Argentina, Brazil, Colombia, Chile and Mexico. PEER is a simple average of the 10 OECD countries with the lowest GDP per capita (excluding Latin American members): Czech Republic, Estonia, Greece, Hungary, Latvia, Poland, Portugal, Slovak Republic, Slovenia and Turkey. For Argentina, PISA data refer to Ciudad Autónoma de Buenos Aires only.

Source: OECD Educational Finance Indicators; OECD PISA 2015 database; OECD (2016c) 
Figure 12. Socio-economic gaps in tertiary education enrolment are among the largest in Latin America

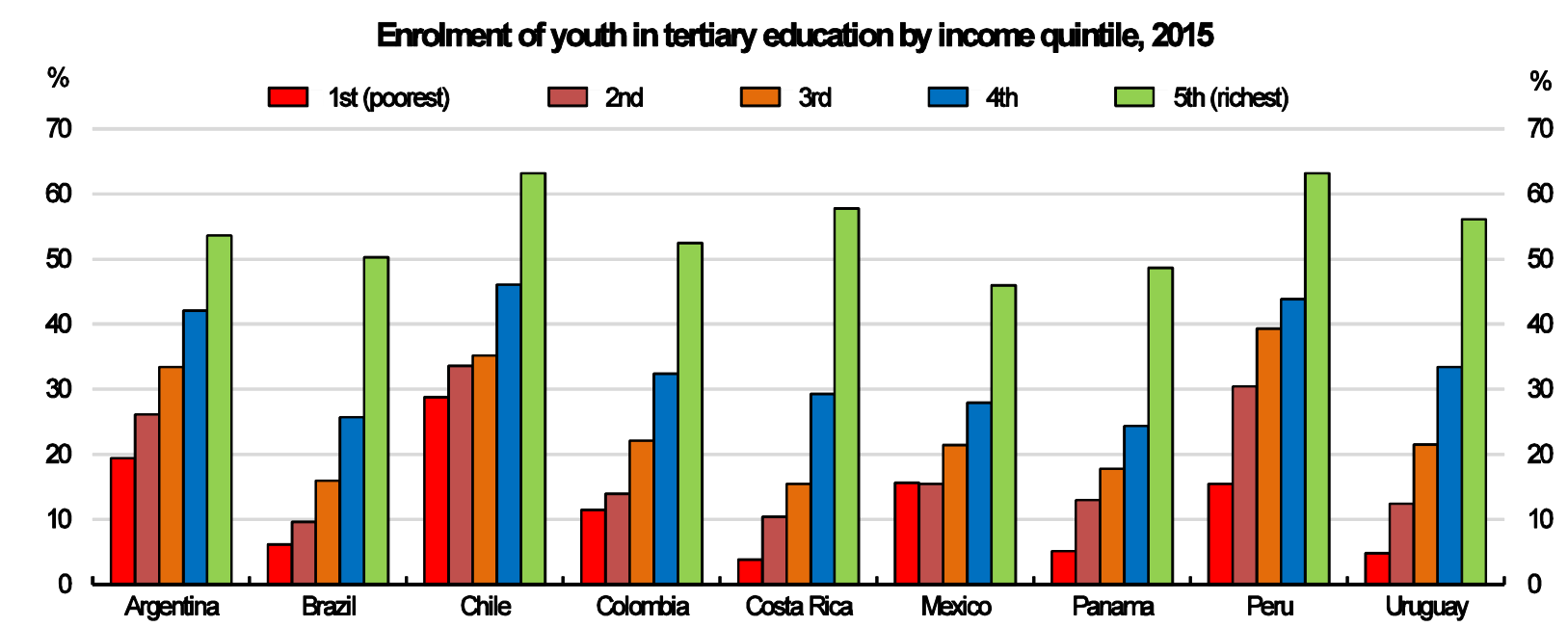

1. Data refers to 2014 for Mexico.

Source: CEDLAS and the World Bank, Net enrolment rate: Tertiary Education, Socio-Economic Database for Latin America and the Caribbean (SEDLAC).

\section{Making educational outcomes the main policy target and re-balance the spending mix}

There is a constitutional mandate to increase education spending to 8\% of GDP in 2018. While education is a cornerstone of Costa Rica's successful social model, an education spending target that is inscribed in the constitution is unique among OECD countries. There is also no underlying rationale for this specific target, which represents a higher level of spending than in any OECD country. The focus needs to shift from inputs to outcomes in order to ensure that this high level of investment is matched by strong results (OECD, 2016b; OECD, 2017c). Overarching performance targets should be established and supported by strong evaluation arrangements. Clear and verifiable performance-based targeting should be established against which to measure the success of education policies. While improvements to data collection and management have been made (OECD, 2017c), better information on student and school performance is needed to allow the evaluation of outcomes, direct resources where they are most needed and make evidence-informed improvements (discussed below).

Re-balancing the spending mix away from tertiary education and towards the earlier years would also improve outcomes and better address inequalities. In particular, resources should be channelled to early childhood education and care and secondary education to address current deficiencies and to better reflect demographic patterns. This could be achieved while accommodating the anticipated future growth in tertiary education enrolments through reforms to the funding arrangements for universities (see below) (OECD, 2016b; OECD, 2017c). 


\section{Increasing access to quality early childhood education and care}

Quality early childhood education and care (ECEC) reduces the impact of socioeconomic background and improves skill accumulation, employment prospects and earnings later in life (Cunha et al., 2006; OECD, 2007; Almond and Currie, 2011; OECD, 2016b). Expanding ECEC services would also facilitate women's participation in the labour market, particularly given the high barrier that care responsibilities create for Costa Rican women (Figure 8).

ECEC remains underdeveloped, despite significant expansion in enrolments. In 2000, only $7 \%$ of 4 year olds and $83 \%$ of 5 year olds were enrolled. By 2014, this had grown to $63 \%$ of 4 year olds and $90 \%$ of 5 year olds. However, enrolment rates remain low by OECD standards, particularly among those aged 3 years and under. Just $6.5 \%$ of 3 year olds are enrolled in ECEC compared with over 40\% in Brazil, Chile and Mexico and 70\% across OECD countries. Moreover, enrolment rates are much lower for children living in rural areas and from low-income families and these disparities are growing (Estado de la Nación, 2015; OECD, 2016b; OECD, 2017c). Quality also needs to be improved, with many services focussed on basic care and nutrition with limited attention given to skills development (OECD, 2017c).

Costa Rican authorities recognise the importance of expanding ECEC. The current National Development Plan includes a goal to increase coverage of Interactive II (4 year olds) from $63 \%$ to $69.5 \%$ between 2015 and 2018, with expansion being prioritised in 75 target districts with low enrolment and high poverty rates (MIDEPLAN, 2014). In the first half of 2017, Interactive II coverage stood at $66.1 \%$, and preliminary data suggest further advances have been made in the second half of 2017. While this expansion, including the focus on disadvantaged regions, is welcome, a more ambitious expansion plan with greater targeting of resources is needed to more effectively reach the most disadvantaged children and narrow the socio-economic divide (OECD, 2017c).

Actions to improve the quality of ECEC in Costa Rica have also been taken. In 2014, a new preschool curriculum was introduced to align programmes across the two years of preschool (Interactive II and the Transition phases, covering 4-5 year olds). It aims to better prepare children for primary school by taking a more holistic approach to development and placing greater emphasis on the development of early literacy skills. However, implementation has been a challenge due to the weak capacity of the teaching workforce, large class sizes and limited parental engagement. Stronger training and support are needed for teachers and parents so they are better placed to help children, particularly disadvantaged children, to develop their early literacy skills and successfully transition to primary school (OECD, 2017c). Greater efforts are also need to improve quality assurance and monitoring. While care services are subject to a set of minimum standards, the requirements are limited and monitoring is inadequate. A more comprehensive set of minimum standards should be established and enforced across all care centres (OECD, 2017c).

Another recent major initiative is the establishment and current implementation of a new early childhood policy, which aims to support the holistic development of children aged 0-8. Spanning the period to 2021, it includes plans to increase the provision of community-based care centres and create an overarching information management system to improve policy making and targeting (OECD, 2017c). In addition, with the aim of achieving universal preschool enrolment, the Higher Council for Education (Consejo Superior de Educación, CSE) recently established a policy to make the completion of preschool a requirement for children enrolling in primary school. While the preschool is 
already compulsory from the age of 4 and the constitutional right of universal access to primary education will still take precedence, this policy is a potentially useful lever for encouraging preschool enrolment. This policy will be phased in over two years and to support its implementation, efforts to identify all children not enrolled in preschool are underway and preschool-aged children currently enrolled in the care system will also receive education services.

Lifting public funding for ECEC would facilitate further improvements in access and quality. As discussed, this should be achieved by re-balancing the current budget rather than increasing the already high levels of public spending on education. While preschool education is currently funded out of the education budget, it was assigned just $9.3 \%$ of funding in 2016 (OECD, 2017c). On the care side, it is hard to accurately estimate public funding, but it appears to be low (OECD, 2017c). Funding from the Social Development and Family Allowances Fund (FODESAF), which is the main source, amounted to roughly $0.2 \%$ of GDP in 2016, but there are also other sources, such as municipalities and private and civil society organisations. Classifying all spending on early childhood education and care under the constitutionally-mandated spending on education would facilitate the expansion of services.

Establishing a lead agency for the whole sector would also improve coordination. While Costa Rica is not unique in having several ministries and agencies involved in ECEC, it is unusual in having no institution with overall responsibility for delivering national policy. Leadership for the provision of preschool education is currently concentrated in the Ministry of Public Education (Ministerio de Educación Pública, MEP), but there is no lead agency for care services, with direction divided across three major government ministries/agencies: the Ministry of Health, the National Child Welfare Agency (Patronato Nacional de la Infancia, PANI) and the Joint Social Aid Institute (Instituto Mixto de Ayuda Social, IMAS). Each agency manages its own resources, sets its own standards and objectives and determines its own expansion plans. In 2014, the National Network for Childcare and Development (Red Nacional de Cuido y Desarrollo Infantil, REDCUDI) was established to improve coordination between the different public and private providers of care services; through the Consultation Commission of the Childhood Network $^{2}$ in charge of the inter-institutional competencies and the various types of childcare services, and aimed at recommending general policies and strategic directions to the care and child development system. This is a very positive reform and REDCUDI is well positioned to help advance coordination on the technical front. However, while improved articulation processes between the MEP and REDCUDI are being implemented with the aim of strengthening REDCUDI, it currently lacks the political influence, institutional capacity and mandate to affect the degree of transformation that is needed in the sector $(\mathrm{OECD}, 2017 \mathrm{c})$. Vesting responsibility for the whole sector in one agency would strengthen leadership and create a clear champion for reform.

Costa Rica recognises the value of improving coordination in education, and the social sector more broadly. With the goal of improving coordination in the social sector, a bill was presented to the Legislative Assembly in May 2016 to transform the current Ministry of Human Development and Social Inclusion by granting it the resources and staff to

\footnotetext{
${ }^{2}$ In this commission, according to Law 9220, Ministers or Viceministers from the Ministry of Education, Ministry of Health and Ministry of Labour and Social Security participate. Also, hierarchs from institutions such as: PANI, INAMU, CCSS and the Technical Secretariat of REDCUDI participate.
} 
enable it to fulfil its current mandate as the social sector coordinator (Bill 19.960). It would act as the coordinating agency across the Ministries of Health, Public Education, Labour and Social Development and PANI, with the aim of offering joined-up services. This could facilitate the development of a holistic approach to early childhood development and more effectively reduce inequalities by tackling the multiple barriers faced by disadvantaged children.

Costa Rica has already been moving towards this more targeted and joined up approach to social services in recent years, for example, by establishing the Bridge to Development (Puente al Desarrollo) Strategy in 2015 (OECD, 2017b). Led by IMAS, this programme unified 30-odd separate programmes into a single system. This strategy has several positive features. For example, it uses newly-developed information systems to actively target services to families most in need. This is more effective in reducing inequalities and improving spending efficiencies than the previous system where families had to identify and seek out entitlements themselves, resulting in many programmes largely benefiting middle- and high-income families (OECD, 2016b). The programme also involves more active participation of social workers, with assistance tailored to the individual needs of families, and made conditional on requirements that are relevant to their circumstances, such as participation in training programmes or children's school attendance. The data collected as part of the programme is already being used to improve service delivery. Going forward, these data will also assist in the systematic evaluation of these programmes. As highlighted in the 2016 Economic Assessment and Araújo and Guichard (2018), evaluation will allow further improvements to the programmes to be made, as well as facilitate improvements in spending efficiency by identifying and allowing resources to focus on the most effective interventions and ensuring that the programmes are reaching those most in need.

In ECEC, there are also initiatives underway to more effectively target the most disadvantaged children, however, greater efforts are still needed. The targeting of preschool expansion to 75 districts with low enrolment and high poverty rates as part of the National Development Plan is welcomed. In addition, the new early childhood policy includes plans to create an overarching information management system to improve policy making and targeting (OECD, 2017c). As a step towards this goal, a georeferenced database of centres and child identifiers is expected to be ready in the first half of 2018. However, there is still limited information available on current and prospective demand to inform future expansion $(\mathrm{OECD}, 2017 \mathrm{c})$. Initiatives are also underway to increase outreach in order to identify and enrol preschool-aged children who are not in the education system. For example, a door-to-door census in Heredia led to the identification of 160 preschool-aged children who were not in the education system, and the subsequent enrolment of 131 of them. As part of a programme with UNICEF, early childhood facilitators will be employed in 43 priority districts to identify children who are not enrolled in preschool.

There is room to continue with the current approach of expanding preschool through the existing network of primary schools. This network reaches the most remote parts of the country and many primary schools have spare capacity due to falling student numbers. Greater attention to delivering ECEC services through alternative approaches to the traditional centre-based model could also help reach the most disadvantaged communities. In 2014, around 1500 children attended community-based care provided in the homes of "community mothers" and over 100000 children benefited from the Nutrition and Education Centres - Child Integral Care's (Centros de Educación y Nutrición Centros Infantiles de Atención Integral, CEN-CINAI) home visit programme. 
However, unlike in other Latin American countries, such as Colombia, Bolivia and Mexico, community- and family-based programmes are not well developed. Enhancing such programmes could provide a cost-effective way to achieve wider coverage, particularly in remote areas, and could also help strengthen home learning environments.

The Costa Rican authorities are currently undertaking a feasibility study to explore options for, and ways to manage, alternative arrangements for the delivery and financing of care services. Public care services are currently free-of-charge for all children. As a way to expand public care services in an equitable way, consideration could be given to introducing income-based fees. The majority of women in the first three income quintiles who are not in the labour force report that care responsibilities are a barrier to working (Figure 8). Often they do not have access to public care services, and are unlikely to be able to afford private care. Introducing income-based fees, similar to those in France or Norway, could enable parents to access care services at a lower cost while also increasing non-government revenue for the expansion of ECEC, but would need to be carefully managed to ensure that fees are based on the ability-to-pay and do not pose barriers to access. In addition, partnerships with local governments and private providers should be encouraged as a means to improve access and quality. The involvement of municipalities in funding public care services is still limited. The Childhood Care and Development Centre (Centro de Cuido y Desarrollo Infantil, CECUDI) was created in 2010 to incentivise local investment, with the cost of the centre shared between the national government and municipalities. For example, in Curridabat the national government covers construction costs and the municipality provides the land and operates the services, with donations from other local participants. While this is a promising model, reducing administrative complexity would facilitate further expansion of partnerships between the central government, municipalities and private providers, as long delays in approval processes and operational procedures are currently a barrier (OECD, 2017c). In addition, clear and enforced minimum standards are needed to ensure that all services meet quality benchmarks regardless of the provider (discussed above).

\section{Improving the quality of teachers and schools}

Raising the quality of teachers and school leaders is the most important challenge for basic education in Costa Rica. Recent years have seen important steps to increase the level of qualification required to enter teaching and virtually all teachers now hold tertiary degrees. However, teachers and school leaders are poorly prepared, recruited and supported, and clear expectations and accountability are lacking. Moreover, the weak capacity to evaluate the school system constrains the development of policies that could raise educational outcomes and reduce inequalities by, for example, targeting assistance and resources where they are most needed (OECD, 2017c).

Teacher assessments reveal significant gaps in teachers' knowledge of core subjects and there is a wide-spread consensus that many initial teacher training programmes are very low quality (OECD, 2017c). The vast majority of teacher education programmes are not accredited and universities have full autonomy over the programmes. As part of efforts to raise the quality of initial teacher training, a welcome proposal is being discussed to make accreditation mandatory for all teaching programmes in private universities (Bill 19.549). The OECD has also recommended strengthening the initial teacher selection process and support for new teachers, by introducing an entrance examination, a probationary period, and a structured induction programme (OECD, 2017c). 
Costa Rica also lacks an effective evaluation system for existing teachers. Appraisals are largely an administrative requirement, and virtually all teachers receive positive ratings (OECD, 2017c). There is also a lack of ongoing support and opportunities for professional development. The OECD has recommended that mechanisms to encourage and support teachers to learn and develop be introduced, including the establishment of a framework for evaluation and professional development (OECD, 2016b; OECD, 2017c)

Costa Rica has undertaken a series of initiatives over the last decade to strengthen schools and improve their quality. This includes a major initiative to modernise the curriculum which is due to be completed in 2018. This new curriculum emphasises critical thinking over rote memorisation, and has great promise as a means of engaging students as more active learners and ensuring that they gain skills that are more relevant to society and the labour market (OECD, 2017c). However, despite training, many teachers are not adequately prepared to deliver the new curriculum and weak pedagogical skills and a shortage of learning materials, such as textbooks, are significant obstacles to classroom implementation.

Additional efforts that have been made to improve the quality of schools include the establishment of a unit dedicated to quality management and evaluation within the MEP, the development of guidelines for school self-evaluations and reforms of the school supervision system. However, school evaluation policies and practices are still in the nascent stage. The OECD has recommended further strengthening school supervision by setting clearer standards for the evaluation of school quality and criteria to focus efforts on the schools that are most in need (OECD, 2017c). Establishing common indicators, shared data collection and a single information system would increase accountability and allow data to be used to make improvements. Costa Rica should consider creating a dedicated independent evaluation agency to promote more evidence-based and resultsdriven policies and support the development of a stronger culture of evaluation at all levels of the system (OECD, 2017c).

Costa Rica's growing awareness of the central role that schools play in improving education outcomes is reflected in the 2008 declaration of Quality Schools as the Axis of Costa Rican Education, in measures to improve leadership skills in schools, and in the 2010 reform to refocus the role of school supervision from external control to support for internal leadership. However, several obstacles need to be overcome to realise this vision of school-led improvement. School leaders continue to play a limited role as instructional leaders (e.g. setting goals for improvement, classroom observation, and mentoring and motivating teachers). The OECD has therefore recommended that Costa Rica improves the relevance of initial and in-service leadership development programmes and establishes peer-learning schemes. The creation of instructional leadership positions within schools, with clear responsibility for the professional development of teachers, would improve pedagogical knowledge and teaching quality (OECD, 2017c).

Better information on student and school performance would allow resources and support to be targeted at underperforming schools. While Costa Rica has carried out national assessments involving a small sample of schools since 2007, it is primarily to inform policymakers about whether students are meeting national learning objectives, and it carries no stakes for schools, teachers or students. Costa Rica should consider applying the assessment to the school census so that the performance of individual schools can be benchmarked against national standards and similar schools, and the MEP has better data to inform policies and resource allocation (OECD, 2017c). In comparing school-level results, performance outcomes could be put into context to enable fair comparisons. For 
example, Brazil and Colombia use a multi-dimensional index that takes account student performance, school progress, grade repetition and factors relating to the school environment (OECD, 2016d).

\section{Reducing the high drop-out rate}

Tackling the high drop-out rate requires a multi-faceted approach encompassing measures to equip teachers to provide high quality instruction and a relevant curriculum that keeps students engaged (as discussed above), in combination with more targeted measures to identify and provide extra support to at-risk students. Costa Rica is already making progress in this area, particularly through the Yo me Apunto programme, which was launched in 2015. The programme aims to reduce the drop-out rate in 85 target secondary schools through early detection and intervention starting at primary school. High schools in the programme have reduced drop-out rates from $14.4 \%$ in 2013 to $9.2 \%$ in 2017 . While it is early days for the programme, it has the potential to create the conditions for school success in the most disadvantaged communities (OECD, 2016b; OECD, 2017c). The OECD has therefore recommended that this programme be systematically evaluated, and if found to be successful, scaled up (OECD, 2016b).

In common with many countries, Costa Rica faces the challenge of transforming the focus of its upper secondary system from preparing a small elite for university to catering to a wider group of students, including those who will enter the workplace or pursue other training options. The growing skills divide, where low-skilled workers are confronted with an increasingly difficult labour market at the same time that the wage premium for skilled workers is growing, highlights the need for a more inclusive system. The OECD has therefore previously recommended developing a vocational education track in close conjunction with employers (OECD, 2016b; OECD, 2017c).

In developing a more inclusive system that better meets labour market needs, there is an increasing focus on technical schools. In Costa Rica, these technical schools include grades 6 to 9 as well as upper secondary levels, and students pursue technical and academic (Bachillerato) qualifications simultaneously. Just over a fifth of entrants to secondary school are in technical programmes, which is much lower than in OECD countries. However, this track has been growing and there are ambitious plans for further expansion. Outside of the formal education system, the National Training Institute (Instituto Nacional del Aprendizaje, INA) is funded through levies on employers and provides short vocational education and training (VET) courses. INA programmes serve as an alternative path to the labour market for students who have dropped out of secondary education, but a lack of coordination with the MEP makes it difficult for students to re-enter the formal school system (OECD, 2017c). However, ongoing work on the qualifications framework is also expected to make it easier for students to receive credit for their INA qualifications within the formal education system. In line with the OECD's recommendation to develop vocational education in close conjunction with employers (OECD, 2016b), partnerships with employers are also being developed and both INA and MEP are establishing programmes which include more hands-on experience in the workplace. In December 2016, the government approved a new apprenticeship track in upper secondary education and in early 2017 started a small-scale pilot programme involving four technical schools which prepare students in the automobile sector. Students who opt for this apprenticeship track must have completed lower secondary school, and will divide their time between the classroom and workplace. After completing the programme at end of the $12^{\text {th }}$ grade, students will receive a diploma of mid-level technical skills and the Bachiller. In parallel, the Legislative Assembly is 
discussing a reform to establish an apprenticeship track which also regulates the contractual situation of students in the workplace (Bill 19.378). It is recommended that these pilot programmes are monitored and evaluated and avenues to increase vocational education continue to be explored.

Despite these efforts, some institutional features are holding back the attractiveness of technical schools and the expansion of the vocational education system. Costa Rica lacks the kind of dedicated vocational upper secondary colleges that are found in many countries, which can be a focus for developing technical skills, employer engagement and work-based learning opportunities while also postponing the choice of career until the upper secondary level. Instead, in Costa Rica, most technical schools are, in practice, largely academic institutions since they include grades 6 to 9 as well as the upper secondary grades and all senior students pursue both the final Bachillerato and a technical qualification. In contrast, many countries maintain a comprehensive curriculum through lower secondary school and then introduce a vocational track in upper secondary school. To accommodate the different tracks, lower and upper secondary schools are separated. This has the advantage of postponing students' choices of vocational specialisation until upper secondary school, facilitating better career choices. It also postpones the time when students must travel far or live away from home to pursue specialist upper secondary education. The OECD has therefore recommended that Costa Rica considers gradually moving towards separate lower and upper secondary schools (OECD, 2017c). This would allow specialised technical colleges to develop with a central mission of teaching technical skills, and including greater links with employers and the labour market. This could also include moving towards the dual systems that countries such as Austria, Germany and Switzerland have, where students in the apprenticeship route do not have the equivalent of Costa Rica's Bachillerato, but normally have the option of studying for examinations which would allow them to subsequently gain university entrance. This could be pursued in conjunction with reforms to the current Bachillerato qualification system (discussed below).

In addition to making vocational education a more attractive option, reforming the senior secondary school assessment system (Bachillerato) could also reduce the drop-out rate. Bachillerato has a binary-pass criterion, so the third of students who stay in school until the final year but fail Bachillerato have nothing to show for their efforts, limiting the attractiveness of upper secondary studies for many (OECD, 2017c). The OECD has recommended that the current binary-pass criterion be replaced with a pass threshold for each of the six individual subjects to better recognise partial achievement and that further consideration be given to adopting a more flexible qualification system, as has been done in other countries such as Australia and New Zealand (OECD, 2017c).

\section{Addressing skill shortages}

The education system has not kept pace with ongoing structural transformation towards high technological- and skill-content sectors, resulting in skills shortages despite the high levels of unemployment. Skill mismatches harm productivity growth, and a lack of qualified personnel is one of the main self-reported barriers to innovation among Costa Rican firms and the majority of employers do not think the education system is meeting the economy's needs (UCCAEP, 2011; Adalet McGowan and Andrews, 2015; MICITT, 2016). Increasing basic skills would significantly raise inclusive growth, and initiatives such as the new school curriculum and further developing vocational education should better prepare students for higher education or the workplace. 
The OECD has also highlighted the need for significant tertiary education reforms (OECD 2017c). Costa Rican universities have a high level of autonomy and few incentives to respond to labour market needs. While university autonomy is a wellrespected principle across OECD countries, this is usually matched by strong steering and accountability mechanisms to ensure that tertiary institutions meet basic standards of quality and serve societal purposes. In Costa Rica, such accountability mechanisms are very limited, and there is no permanent coordination body or long-term plan to steer the sector towards common goals (OECD, 2017c).

Public spending on tertiary education has roughly doubled as proportion of GDP since 2000 and currently amounts to $1.5 \%$ of GDP (OECD, 2017c). The vast bulk of funding (around 90\%) for public universities comes from the government's Special Fund for Higher Education (FEES). Despite its size, it does not have an attached steering, monitoring and evaluation framework and it creates incentives to increase places in courses that are less expensive to deliver, resulting in a bias towards social sciences. The small number of STEM (science, technology, engineering and mathematics) graduates and post-graduates in all subjects poses a significant obstacle to Costa Rica's ambition of developing a more high-technology, knowledge-intensive economy (OECD, 2016b; OECD, 2017c). It is recommended that Costa Rica introduces funding mechanisms to enhance labour market relevance and outcomes, such as performance-based funding whereby a portion of funding is conditional on meeting targets such as the number of graduates in specific fields, or the employment and earning outcomes of graduates (OECD, 2016b; OECD, 2017j). While authorities recognise the issue, proposals to reform the FEES system have met with considerable resistance from stakeholders and to date, have not been progressed.

Public universities heavily subsidise tuition and provide scholarships so that students whose school results are good enough to gain entry to a public university face few financial barriers, enabling young people from disadvantaged backgrounds to attend university. However, over half of Costa Rican students enrol in private institutions, which are excluded from the system of generous public subsidies (OECD, 2017c). These funding arrangements are unsustainable as tertiary education spending has roughly doubled as a share of GDP since 2000 and further growth in enrolments is anticipated, which will contribute to Costa Rica's continued economic development. These arrangements are also inequitable as the majority of students who benefit from public universities are from wealthier backgrounds. In 2015, 3.8\% of young people from the lowest income quintile enrolled in tertiary education (Figure 12). While the majority $(70.1 \%)$ of these low-income young people enrolled in public universities, this means that just $2.7 \%$ of young people in the lowest income quintile attended a public university. In contrast, while only $41.8 \%$ of those from the highest income quintile who enrolled in tertiary education attended a public university, the much higher enrolment rate $(57.8 \%)$ among this group means that almost a quarter of those from high income families benefited from public universities. Indeed, students who can afford to attend a private secondary school are twice as likely to gain entry to a public university as those who attend a public secondary school. Conversely, students in private universities have almost no access to scholarships, although they face larger fees, resulting in just $1.1 \%$ of youth from the lowest income quintile enrolling in private tertiary education, versus over a third of those from the highest income quintile.

A new tertiary funding and student support system needs to be developed to allow more effective and equitable cost sharing between the government and the students who benefit from tertiary education (OECD, 2017c). This new arrangement should target financial 
support to students on the basis of need and their ability to benefit. This should include a regulated but substantial increase in fees in public universities (OECD, 2017c). Scholarships and government-backed loans should be offered to students pursuing quality programmes in either public or private universities, replacing the current arrangements which primarily benefits public university students through subsidised tuition and scholarships (OECD, 2017c).

\section{Strengthening competition}

Weak competition in Costa Rica is holding back convergence to higher-income countries. Regulations which restrict competition can hinder efficiency gains, innovation and productivity-enhancing resource allocation and contribute to inequality by raising consumer prices and increasing the distribution of wages (Nicoletti and Scarpetta, 2003; Aghion and Griffith, 2005; Conway et al., 2006; Song et al., 2015; Denk, 2016; Ennis et al., 2017). Competition plays a key role in allowing resources to flow to their most productive uses. Estimates suggests that more efficient resource allocation could increase Costa Rica's MFP by more than 50\%, which is similar to other Latin American countries, but higher than more developed countries, such as the United States (Alfaro and Garita, 2018).

Product market regulations in Costa Rica are more restrictive than in any OECD country except Turkey and they also compare poorly with other Latin American countries, including Chile, Colombia and Mexico (Figure 13). State controls are particularly restrictive, with large government involvement in network sectors, price controls and poor governance of state-owned enterprises (SOEs) (Figure 14, Panel A). Barriers to entrepreneurship in Costa Rica are also high due to the licence and permits system, administrative burdens on small firms, anti-trust exemptions and restrictions in network sectors (Figure 14, Panel B).

\section{Granting the competition authority more independence and resources}

Implementation issues are hampering the effectiveness of competition policy in Costa Rica. The main enforcement agency, COPROCOM (Comisión para Promover la Competencia), is an agency of the Ministry of Economy, Industry and Commerce (MEIC) and does not have administrative and budgetary independence. Staff of the Commission's Technical Support Unit are employed by MEIC and COPROCOM does not have its own legal personality and is reliant on the Attorney General to defend its decisions in court. COPROCOM is also under-resourced - the Commission's Technical Support Unit is understaffed and its budget is low compared with other economic regulators in Costa Rica and similar competition agencies in the region (OECD, 2016b). In addition, Commissioners work part-time for negligible pay, and have a main job elsewhere, raising potential conflict of interest issues. 
Figure 13. Product market regulations are stringent

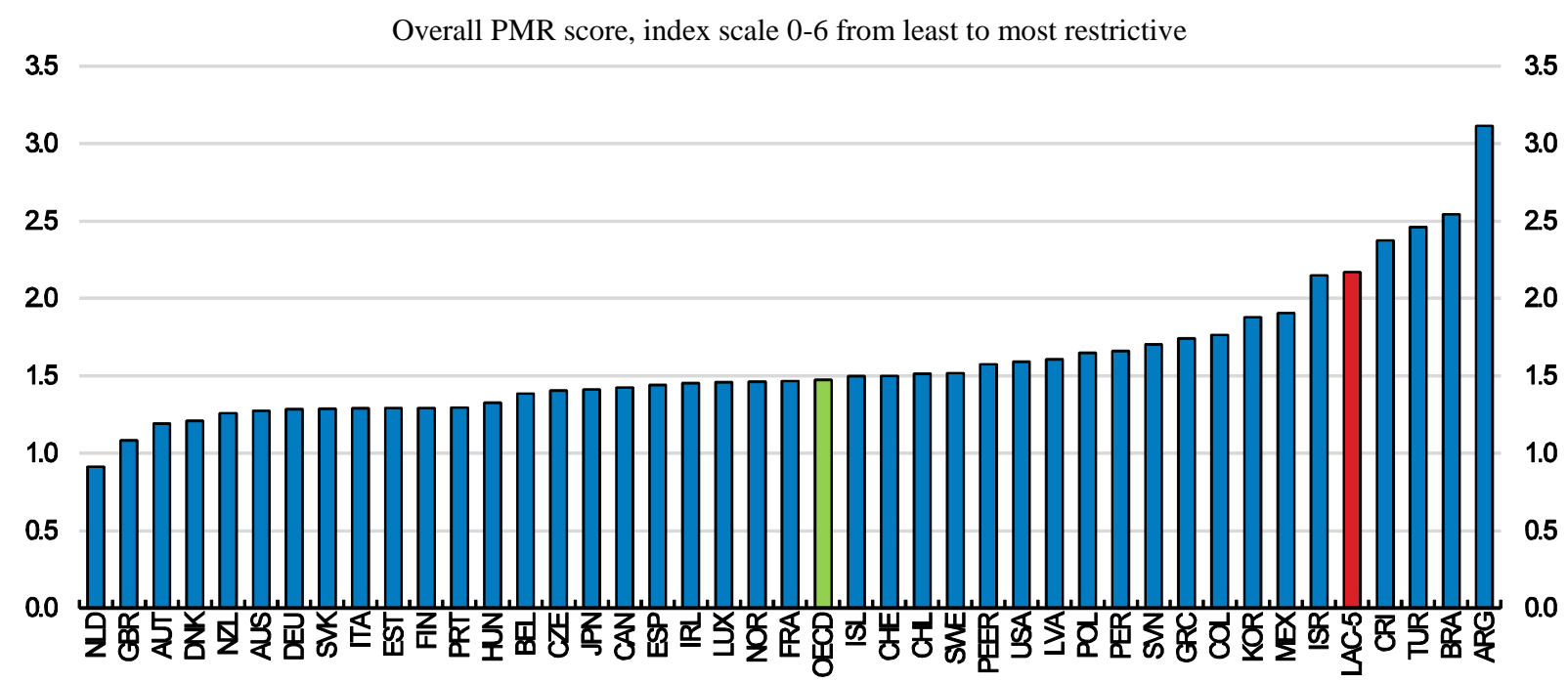

Note: Data refer to 2013. OECD is a simple average of OECD countries. LAC-5 is a simple average of Argentina, Brazil, Chile, Colombia and Mexico. PEER is a simple average of the 10 OECD lowest GDP per capital countries excluding Latin American countries.

Source: OECD-WBG Product Market Regulation database for all LAC countries except Brazil, Chile and Mexico; OECD Product Market Regulation database. 
Figure 14. State controls and barriers to entrepreneurship restrict competition
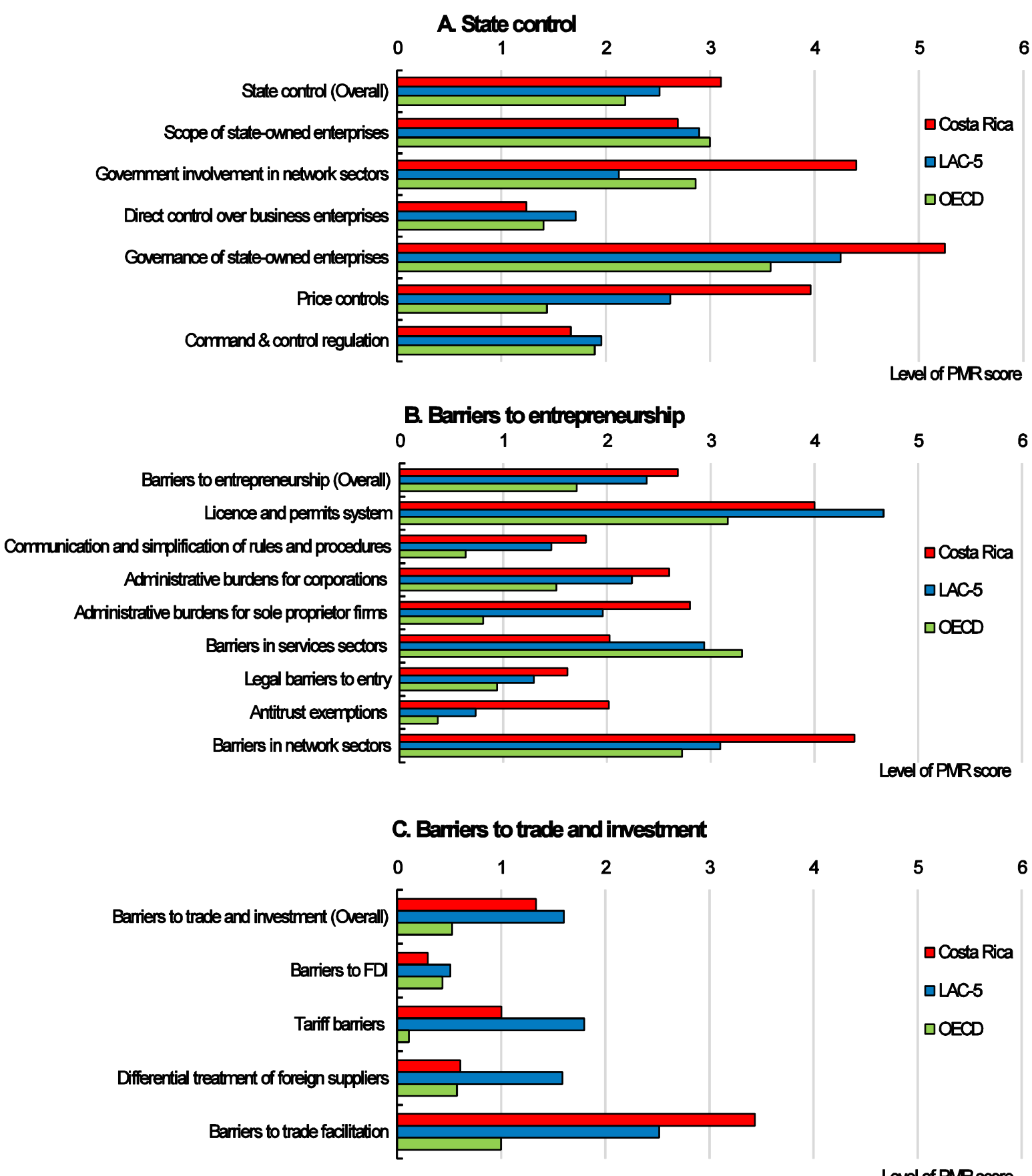

Note: Data refer to 2013. OECD is a simple average of OECD member countries. LAC-5 is a simple average of Argentina, Brazil, Chile, Colombia and Mexico.

Source: OECD-WBG Product Market Regulation database for all LAC countries except Brazil, Chile and Mexico; OECD Product Market Regulation database. 
Costa Rica recognises these issues, and a bill to address them is being considered by Congress and may be adopted in 2018 (Bill 19.996). The bill creates a new National Council of Competition (Conacom) supported by a Secretariat General of Competition. Conacom will be a body of "maximum de-concentration" attached to MEIC but with functional, administrative and financial independence, as well as its own legal personality (OECD, 2016e). The proposed reform also includes measures to improve the process for appointments to the competition authority's board, reduce conflict of interest issues, increase the level of resourcing, and improve flexibility over staff selection and the setting of work conditions and pay. In line with 2016 Economic Assessment recommendations, the bill also grants Conacom the power to conduct market studies and to create a leniency programme for whistle-blowers. It also establishes a new sanction system, with fines determined by the level of the infraction's severity. However, the sanctions may still not be high enough to pose a sufficient deterrent effect in some industries (OECD, 2016e). This bill should be adopted and implemented as a matter of priority.

\section{Assessing and removing unjustified anti-trust exemptions}

Many sectors in Costa Rica are exempt from competition law and although it is unclear what share of the economy this represents, a rough estimate suggests that it may be a third of the economy (OECD, 2016e). These sectors include electricity, fuel transportation/distribution, alcohol distillation, sugar, rice, professional services and maritime transport. As several of these sectors are upstream suppliers, the share of the economy indirectly affected by these exemptions is much greater, which impacts on incentives to improve productivity downstream, decreases international competitiveness and reduces economic resilience (Bourlès et al., 2013; Monteiro et al., 2017).

In most cases, there seems to be no economic justification for the exemptions, and in a number of cases, notably concerning rice, COPROCOM has argued repeatedly that existing exemptions be eliminated. The OECD has recommended that Costa Rica remove all unjustified exemptions (OECD, 2016b; OECD, 2016e). This could increase GDP per capita by $0.08 \%$ (Box 1).

In response, Costa Rica is undertaking in-depth reviews of 25 sectors exempt from competition law between 2017 and 2020 (a review timetable is provided in Table 3.). As of January 2018, two studies had been completed but are awaiting approval, and it is not yet known if they will be released publicly. A further three studies are underway are expected to be completed in first quarter of 2018. While these reviews are a positive first step, removing exemptions is likely to be a controversial and lengthy process. For example, international trade negotiations were the catalyst for liberalisation of the Costa Rican telecommunications sector, and even then, the reforms were only approved following a very close referendum (OECD, 2016b). It is therefore recommended that next steps are mapped out to clarify how these studies will be used to spur concrete action. The review timetable should also be reconsidered, and sectors that are large and/or upstream suppliers (such as electricity) should be reviewed earlier. 
Table 3. Costa Rica is reviewing sectors exempt from competition law

\begin{tabular}{lclc}
\hline \multicolumn{1}{c}{ Sector } & Review year & \multicolumn{1}{c}{ Sector } & Review year \\
\hline 1. Alcohol & $2017-2018$ & 14. Public works concessions & 2019 \\
2. Professional associations & $2017-2018$ & 15. Coffee sector & \\
3. Notary services & $2017-2018$ & 16. Aqueducts and sewage & 2019 \\
4. Vehicle inspections & $2017-2018$ & 17. Lotteries and bingo & 2019 \\
5. Gas stations & $2017-2018$ & 18. Importation and production of fuels & 2019 \\
6. Postal services & $2017-2018$ & 19. Transportation of fuels & 2020 \\
7. Ports & 2018 & 20. Liquid gas & 2020 \\
8. Stevedoring services & 2018 & 21. Electricity generation & 2020 \\
9. Maritime transport & 2018 & 22. Electricity distribution & 2020 \\
10. International air transport & 2018 & 23. Sugar sector & 2020 \\
11. Bus transport & 2018 & 24. Rice sector & 2020 \\
12. Rail transport & 2018 & 25. Social security services & 2020 \\
13. Taxi transport & 2018 & & \\
\hline
\end{tabular}

\section{Improving the governance of state-owned enterprises}

There is a high degree of state control in the Costa Rican economy (Figure 14, Panel A), which restricts competition and leads to operational and allocative inefficiencies and lowers productivity (Hsieh and Klenow, 2009). SOEs play a dominant role in many key sectors, such as electricity, transport infrastructure, banking, insurance and petroleum products (OECD, 2016b; OECD, 2017k; OECD, 2017l). Even liberalised sectors, such as telecommunications and insurance, retain a dominant incumbent SOE. Several of these sectors will be reviewed as part of the in-depth sector studies mentioned above, providing an opportunity to assess not only whether state involvement is justified, but also whether the form of state involvement (including the presence of SOEs) is appropriate.

The governance of SOEs is also an issue. Most SOEs have been created by specific laws, resulting in a lack of uniformity in reporting and operational regulations. Improving SOE governance could have a sizeable impact on growth, boosting GDP per capita by $1.1 \%$ in the long term (Box 1). Recent high-profile cases involving two public banks (the cessation of intermediation activities at Bancrédito and investigations into the business practices of Banco de Costa Rica) have also raised public awareness about the importance of good governance.

To improve governance, the OECD has made a number of recommendations to align practices with the OECD Guidelines on Corporate Governance of State-owned Enterprises (OECD, 2015e; OECD, 2016b; OECD, 2017m). In response, the government launched an SOE Action Plan in July 2017, which is expected to be rolled out by the end of 2018. It includes actions to establish an ownership coordinating entity, develop an ownership policy, improve the composition of SOE boards, improve the corporate governance of SOEs, promote the adoption of international financial reporting standards, and enhance the monitoring and disclosure of SOE performance.

Several actions are already underway. An ownership unit was created as a legal entity in October 2017. A draft decree has also been developed that aims to bring board member nomination processes in line with the OECD Guidelines by establishing a clear and 
transparent nomination policy for SOE board members and chief executives. Authorities are aiming to have the ownership entity operational and the nomination process established before the next round of board nominations takes place after the new administration takes office in May 2018. There are also ongoing efforts to address outstanding issues that have been raised by the OECD. For example, concerns have been raised that the ownership entity will not only be responsible for SOEs, but also other autonomous bodies such as the Regulatory Authority for Public Services (ARESEP) (OECD, 2017m). To address this, in its first two years of operation, the ownership entity will only be responsible for SOEs and after this time, a separate division will be created to oversee the other autonomous bodies. The level of resourcing of the ownership entity has also been raised as a potential issue, as the number of planned staff appears to be small relative to other ownership entities in OECD countries to the number of SOEs it will monitor (OECD, 2017m). The Ministry of the Presidency plans to assess the level of staffing after two years, and make adjustments if necessary.

An additional issue is that many SOEs are established under their own legislation, and in some cases, these laws may need to be changed to avoid conflict with the draft decree. While authorities plan to address this issue through administrative measures initially, legal reform would bring greater stability. It is also expected that a Corporate Governance Bill will be submitted to the Legislative Assembly by April 2018. The content of this bill is not yet clear as it is currently being drafted, but in general terms, it aims to provide cohesion to the public policy on corporate governance and complement the administrative actions that are already underway.

However, the Action Plan does not address level playing field concerns. SOEs often enjoy government-granted revenue streams. For example, the public bank Bancrédito had traditionally relied on state-sanctioned monopolies on the collection of airport exit taxes and the management of a state development fund (OECD, 2017m). Public banks also have the advantage over private banks of a full government guarantee on deposits. On the other hand, public banks must make para-fiscal transfers out of their net income (discussed in Araújo and Guichard, 2018). These transfers do not pass through the national budget and are made directly to government agencies, such as the National Institute of Cooperative Development, the National Commission on Education Loans, the National Commission of Risk Prevention and Emergency Response and the Regime for Disability, Old Age and Death (OECD, 2017n).

Opening entry to FinTech start-ups and innovation would be a way to boost competition and reduce the high costs of financial intermediation. Technology-driven innovation in financial services has the potential to increase competition in the financial sector, improve access to credit, financial inclusion and reduce the cost of cross-border transactions. Several governments have therefore implemented, or are considering options for, FinTech regulatory frameworks. By providing greater certainty to innovating businesses and allowing space for experimentation, these aim to facilitate the development of FinTech while ensuring consumer protection and financial stability. For example, the UK launched a regulatory sandbox in May 2016 to provide a testing ground for new FinTech services, allowing for innovation under equal conditions for all players, while containing any consequences of failure. Several other governments have since created regulatory sandboxes, such as Singapore and Hong Kong. Mexico has also recently approved a bill to create a regulatory framework for FinTech and the European Commission is considering regulatory options as well. 
In Costa Rica, to foster competition in the financial sector, where high transactions costs prevail, the central bank has updated its "Regulations for the Payments System" so that FinTech companies can register with and use the "National System of Electronic Payments", managed by the central bank, and widely used by the population. Building on this positive step, to further facilitate the development of FinTech the Costa Rican authorities should explore options and implement an appropriate regulatory framework.

\section{Reducing barriers to entrepreneurship and streamlining regulatory procedures}

Costa Rica's high barriers to entrepreneurship are reflected in Costa Rica's low level of business dynamism and high rates of informality. Product market regulations are particularly stringent due to the licence and permits system and high administrative burdens for small firms (Error! Reference source not found. 2.14, Panel B). Reducing administration burdens for firms could increase GDP per capita by $1.6 \%$, and streamlining the licences and permits system could add $0.9 \%$ (Box 1).

According to the World Bank's Doing Business indicators, Costa Rica's distance-to-thefrontier score is 81.7 out of a possible 100, which is lower than all OECD countries. It takes 22.5 days to start a business, about 2.7 times longer than the OECD average, costs about 2.2 times as much, and involves 9 procedures. Costa Rica introduced an online platform for business registration in 2012, which significantly reduced the amount of time involved. However, it still takes considerable more time to start a business than in some other countries in the region (World Bank, 2017). Moreover, a mapping of the necessary processes by the Costa Rican authorities suggests that the time to operation (which includes not only business registering, but also obtaining necessary construction, environmental and other permits) is often much longer, taking about six months in an optimistic scenario, and involving 17 processes and 14 public agencies.

The government is working to reduce these business compliance costs. The majority of the 22.5 days it takes to start a business according to the World Bank measure is accounted for by the issuing of a business licence by the local municipality. Therefore, the Ministry of Economy, Industry and Commerce (MEIC) is working with several municipalities to reduce the time and paperwork involved, including by establishing onestop shops in the Brunca, Central Pacific and Chorotega regions. In addition, MEIC and PROCOMER (Costa Rica's export promotion agency) started a joint project in 2016 to extend the sub-national initiatives to simplify and digitalise business processes, not only for the business registration phase, but also to obtain other licences and permits (such as construction, health and environmental permits). The digital platform has now been rolled out to firms within free trade zones, and is currently being extended to all firms. The project aims to reduce the current establishment time from 5-18 months to three months for manufacturing firms, from six months to 30-45 days for service firms, and from 1.5-2 years to six months for agro-industry firms. Areas that are slated for improvement include reducing the time to register foreign employees, obtain sanitation and environmental permits, undergo customs inspections and obtain free trade zone approvals.

These are positive steps, and if the current project is successfully implemented, it could set the stage for even further improvements in the future. Currently, the project involves improving processes within the current legal framework, which may limit what improvements are possible. Second, some of the procedures, such as obtaining a business licence and environmental permits, are the responsibility of local municipalities. Since municipalities have a high degree of autonomy, improving these processes requires consultation and coordination with municipalities on a case-by-case basis. Despite these 
limitations, authorities should continue these positive initiatives, with a view to establishing one-stop shops implemented at the local level, with clear and measurable objectives against which performance, including municipality performance, is benchmarked. As an example of what could be achieved, the number of procedures that an entrepreneur needs to undertake to start a business could be reduced from nine to one if these tasks were instead performed by a one-stop shop, as is the case in the best performing countries according to Doing Business, such as New Zealand.

Other efforts to reduce red tape are also underway. Regulations relating to registering low-risk food products and cosmetics were simplified in 2016. A new online application system for water permits has been introduced (OECD, 2017d). A new method for approving agrochemicals came into force in 2017, which is expected to reduce the approval time from four years to as little as six months, although it is too early to assess its impact. Authorities should continue with their ongoing efforts to lower regulatory burdens.

Costa Rica's Law for the Protection of Citizens against Excessive Administrative Requirements and Procedures (Law 8220) has allowed for "silence is consent" since 2012. If permits and licences are not issued within the statutory time limit, the activity is deemed to be approved. However, "silence is consent" covers only permits, licences and authorisations, and excludes those relating to health, animal health, phytosanitary and environmental issues. There is also an onus on applicants to request "silence is consent", which involves submitting an application which confirms that all the necessary paperwork had been filed and the statutory response time has elapsed. The administration then has three days to either certify that "silence is consent" is granted or provide reasons why it does not apply. These exclusions and requirements may be limiting its use and effectiveness. Unfortunately, information on how often the "silence is consent" rule is applied in cases when the statutory time limit has elapsed is not available. It is recommended that this information be collected with a view to assessing the effectiveness of the "silence is consent" rule is in practice.

\section{Improving the insolvency regime to facilitate the exit of "zombie" firms}

At the other end of the firm lifecycle, facilitating the exit of unviable businesses frees resources to flow to more productive uses. According to OECD indicators of the design features of insolvency regimes, Costa Rica performs above the OECD average. This is largely due to Costa Rica achieving best-practice standards for restructuring tools, while systems for prevention and streamlining of the process could be improved (Adalet McGowan et al., 2017). However, Costa Rica's results according to the World Bank's Doing Business "resolving insolvency" indicator, which are based on a stylised case study and focuses more on implementation than the OECD indicators, are much less positive. According to the World Bank measure, Costa Rica's distance-to-the-frontier score is 34.4 , which is lower than all OECD countries except Turkey and significantly below the OECD average of 74.8. This reflects a debt recovery rate (31 cents in the dollar) that is much lower than OECD countries (75 cents) and countries such as Colombia (72 cents). The estimated time to resolution of three years is also high compared to the OECD average (1.8 years) and comparable countries such as Colombia (1.7 years) (World Bank, 2017).

Recognising these issues, a major overhaul of the insolvency regime is underway. Currently, the regulatory framework for insolvency is dispersed across several pieces of legislation. A draft bill that provides a unified regulatory framework for insolvency is 
expected to be ready shortly. The framework will follow World Bank recommendations and the model used in other countries, such as Mexico, Spain and Uruguay. It will provide for a re-structuring phase based on agreed solutions with creditors, providing the opportunity for the business to trade its way to viability. In the case that the business is not viable, it then provides for a liquidation phase. It aims to expedite this phase, which often takes three years or more currently, with an aim to reduce this to no more than one year. For example, processes will be streamlined by limiting the ability of creditors to appeal asset valuations and creating financial penalties for relatively trivial appeals. In addition, from February 2018, all insolvency cases will be heard in a specialist court.

\section{Continuing efforts to increase the profile and coordination of productivity- related policies}

Improving productivity and inclusive growth requires measures spanning many different policy areas, which poses a particular challenge for Costa Rica given the high degree of public sector fragmentation (Cornick and Trejos, 2016). The Presidential Council on Competitiveness, Innovation and Human Talent, PCCI), modelled after productivity commissions in OECD countries such as Chile and Mexico, was established to raise the profile of productivity-related policies and to coordinate and align policy efforts.

While the PCCI has made positive steps to improve policy development and coordination, its effectiveness could be enhanced if it assumed a more strategic role, its three subcouncils merged, and the technical unit strengthened (OECD, 2016b; OECD, 2017e). To address these issues, a technical committee tasked with establishing an agenda of priorities for the PCCI's work has been created. Furthermore, a bill is being considered to institutionalise the PCCI to ensure its longevity, unify its three sub-councils, strengthen the technical secretariat and add a strategic advisory branch (Bill 20.331). While this is a positive development, it is not yet clear if and when this bill will be enacted and the changes implemented.

\section{Promoting innovation, technological diffusion and integration into global value chains}

The FDI- and export-led economic strategy that began in Costa Rica in the 1980s has contributed to a structural transformation from an agricultural-based economy to one with a more diversified structure that is integrated into global-value chains (GVCs), which has allowed for a sustained expansion of production since the mid-1980s (Rodriguez-Clare et al., 2001; Alfaro and Quesada, 2015). This evolving pattern of production is mirrored in the country's comparative advantage, which, similar to advanced OECD economies, shows an increasingly specialised and sophisticated export basket (OECD, 2017o; Figure 15, Panel A). Building on existing productive experiences and specialisation patterns, Costa Rica could benefit from upscaling opportunities in a number of medium- and hightechnological industrial sectors (Araújo, Linares and Chalaux, 2018; Figure 15, Panel B). The service industry has also started to gain prominence, with an increase in the share of economic activity in knowledge-intensive service industries, such as professional and business services (OECD, 2017e). There has also been a rise in service exports, reflecting an increase in tourism and knowledge-intensive services (professional and business services, and telecommunication, computer and information services) (Figure 16). This diversification and transformation will contribute to economic resilience and spur productivity and income convergence to high-income countries. Although Costa Rica faces the challenge of spreading the benefits of this transformation more evenly, it has the 
potential to improve the population's well-being by creating quality, higher paid formal jobs.

Figure 15. Costa Rica is specialising in complex products

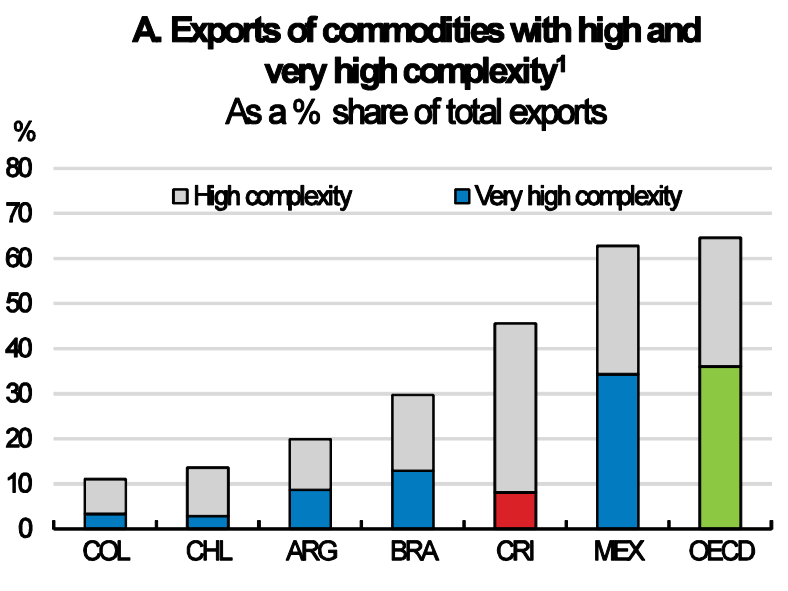

\section{B. Upscale opportunities ${ }^{2}$ for Costa Rica, by complexity and industry}

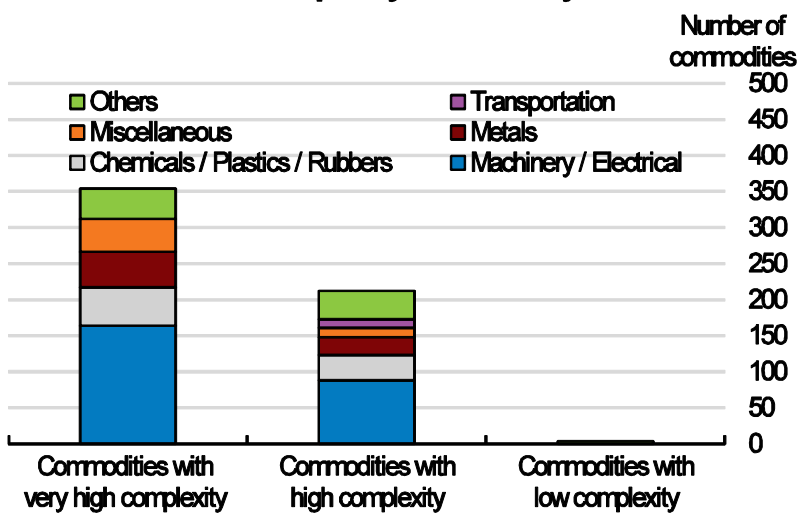

1. "High" and "very high" complexity commodities are those with complexity scores in the 3rd and 4th quartiles of the distribution of the total set of commodities traded worldwide. These are calculated on the basis of the Product Complexity Index $(\mathrm{PCl})$ which is a measure of the relative knowledge intensity of a commodity. An example of a product in the 4th quartile is "Ethylene dichloride", which ranked 10th in 2015 out of 4214 products listed in the Harmonized System 6 classification. A product in the 1st (lowest) quartile is "Cocoa paste wholly or partly defatted" ranked 4201st in 2015.

2. Upscale opportunities are those commodities currently exported with no comparative advantage, with a level of complexity $(\mathrm{PCl})$ higher than the country's complexity index and which are closer to the country's specialisation pattern.

Source: Panel A: Araújo, Chalaux and Haugh (2018); Panel B: Araújo, Linares and Chalaux (2018). 
Figure 16. Knowledge-intensive services are an increasingly important part of the economy
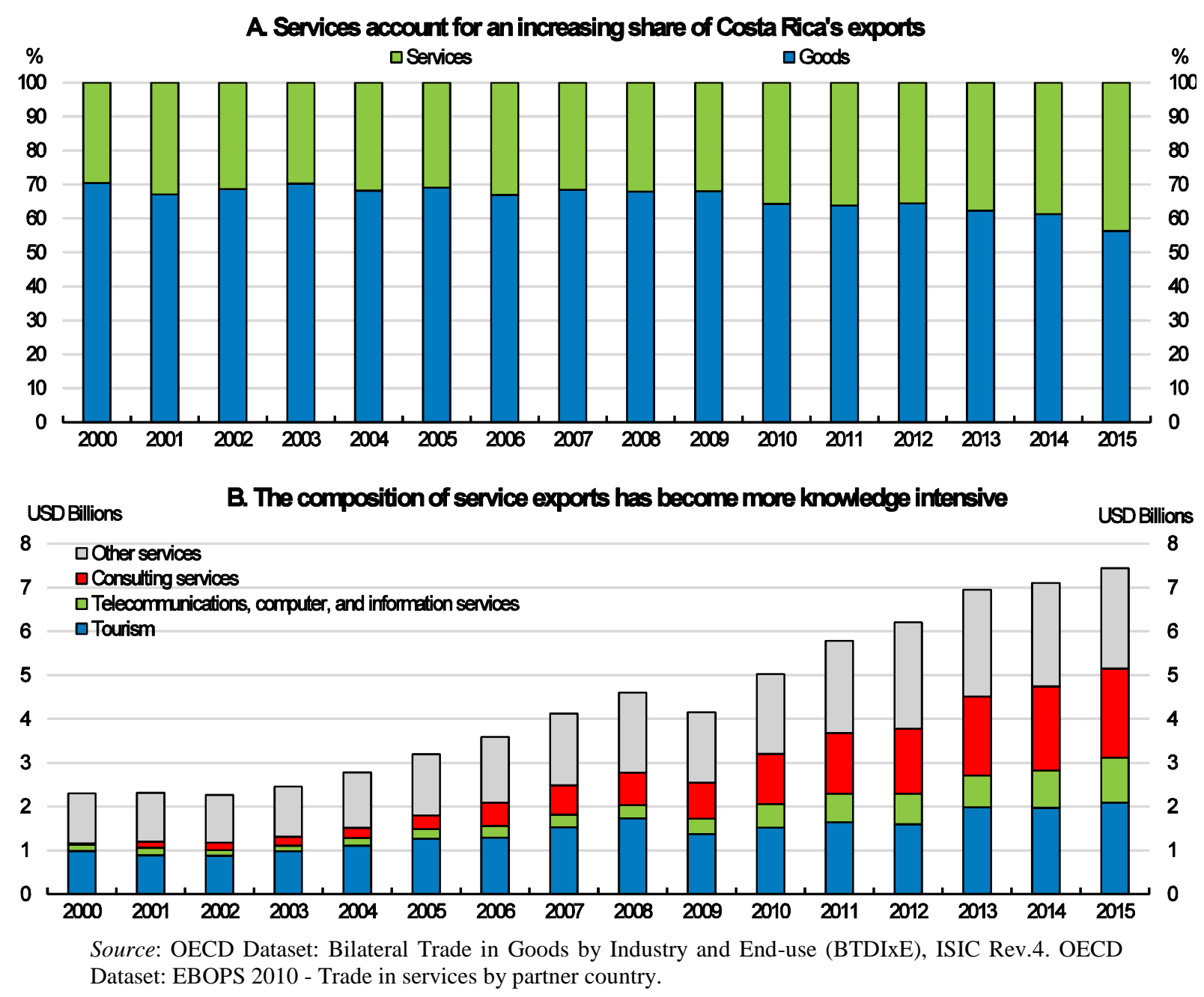

Costa Rica's strong foreign investment inflows have been facilitated by a friendly FDI regime (Figure 17). While regulatory barriers to FDI are lower than the OECD average, restrictions are still stringent in some sectors, including some key network sectors, such as electricity supply and maritime and surface transport (OECD, 2016b; OECD, 2017p). Moreover, Costa Rica restricts trade in many service sectors more than other countries, with particularly high restrictions in road freight transport, cargo-handling and storage and warehouse services (Figure 18). Logistics costs could be reduced and further trade and GVC integration facilitated if these restrictions were eased.

Despite its shift into more knowledge-intensive goods and services, Costa Rica does not score well on innovation input and outcome measures. On the input side, $R \& D$ spending as a share of GDP is on a par with other Latin American countries that have a similar level of development, but it has stagnated in recent years and is well below the OECD average (Figure 19, Panel A). The private sector's contribution is weak, with a large and increasing share of R\&D funded by the government (Figure 20), with limited knowledge transfer to businesses. Costa Rica is also well below the OECD average in terms of the 
share of researchers in total employment (Figure 19, Panel B). Investment in other key forms of intangibles for innovation such as ICT and software spending appear higher than in other Latin American countries (as a share of GDP), but are still several times lower than in OECD countries. On the outcomes side, Costa Rica has low performance in most knowledge and technological production indicators. Publication activity is lower than a number of comparable countries in the region and far below the OECD average. Indicators of intellectual production, such as patents and industrial designs, show that Costa Rica performs well below other Latin American and OECD countries. Costa Rica ranks better than most Latin America countries in terms of trademarks per person, but is still far behind the OECD average (OECD, 2017e).

In addition, innovation and technology use is concentrated among firms in free-trade zones. These high-productivity firms co-exist with low-productivity domestic (including informal) firms. There is limited integration of local firms into the supply chains of multinational firms due to a mismatch between what foreign firms demand and the competencies of the local business sector (OECD, 2017e). As a result, local suppliers provide only $24 \%$ of inputs to multinational enterprises in Costa Rica, and this mostly consists of low value-added activities like packaging and cleaning services (OECD, 2017e). However, there is evidence of positive spillovers from FDI to domestic firms. In the manufacturing sector, firms that supply foreign-owned firms have, on average, $8 \%$ higher labour productivity than firms with similar characteristics that do not have business relations with foreign-owned firms. In the services sector, such firms have $6.4 \%$ higher labour productivity (Sandoval et al., 2018). Moreover, there is an increasingly dynamic services sector, with sophisticated business services and informatics accounting for $45 \%$ of the total sector (OECD, 2017e).

Figure 17. FDI restrictions are relatively low overall

Total FDI Regulatory Restrictiveness, index scale 0-1 from open to closed, 2016

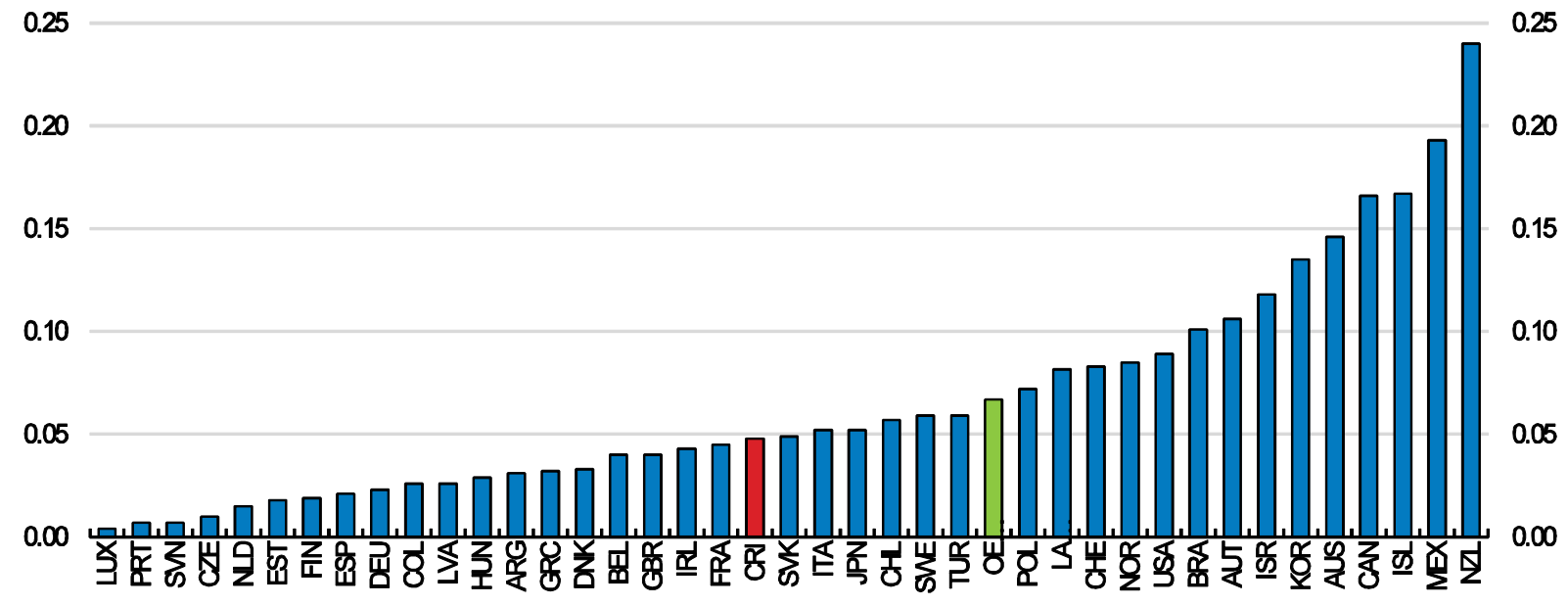

Note: OECD is a simple average of OECD countries. LAC-5 is a simple average of Argentina, Brazil, Colombia, Chile and Mexico.

Source: OECD FDI Restrictiveness Index. 
Figure 18. Services trade restrictions are high, particularly in transport and logistics

\section{A. Overall STR 2017}

Scale 0-1 from least to most restrictive
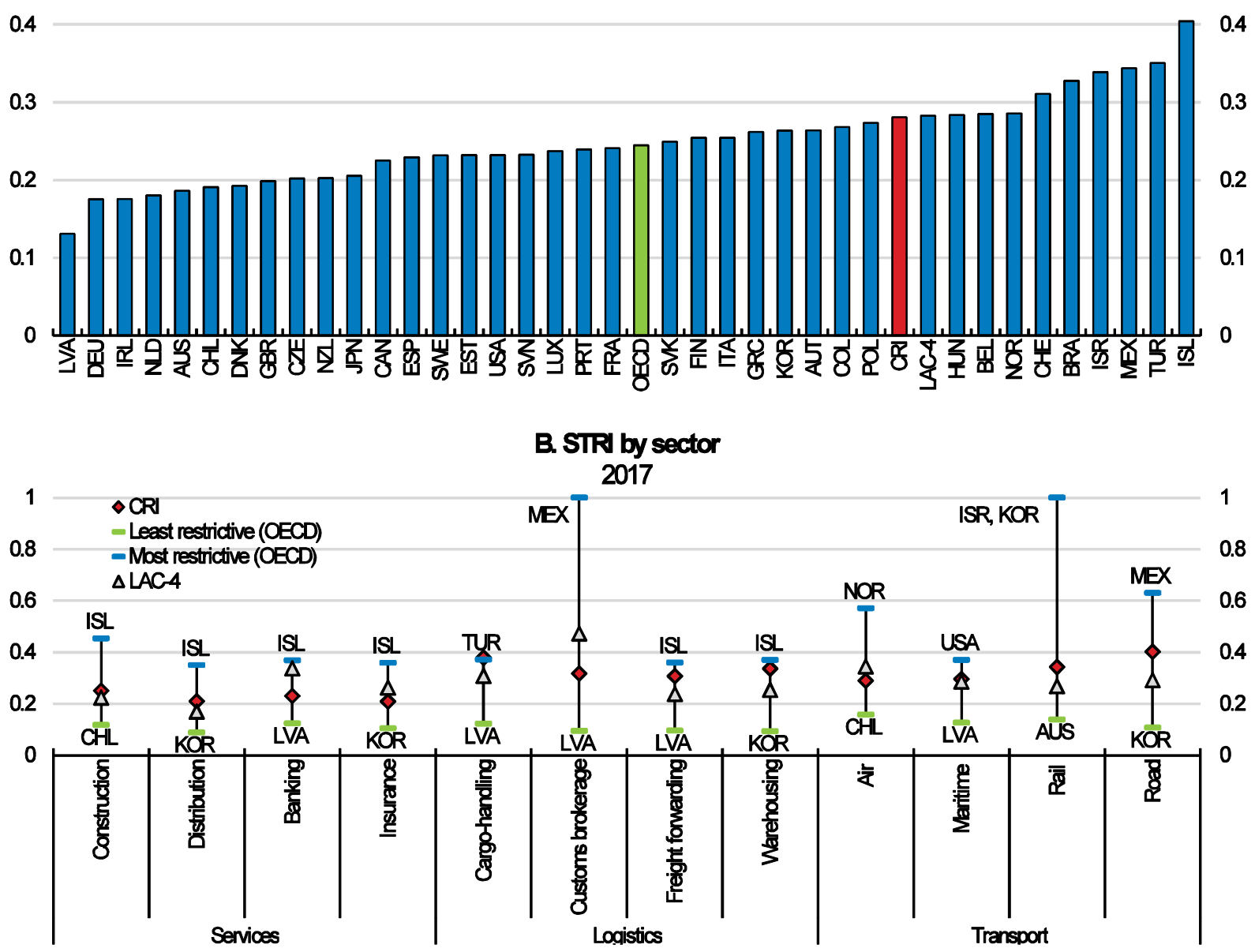

Note: LAC-4 refers to a simple average of Brazil, Chile, Colombia and Mexico. Source: OECD Services Trade Restrictiveness Index (STRI). 
Figure 19. Investment in knowledge-based capital is lagging

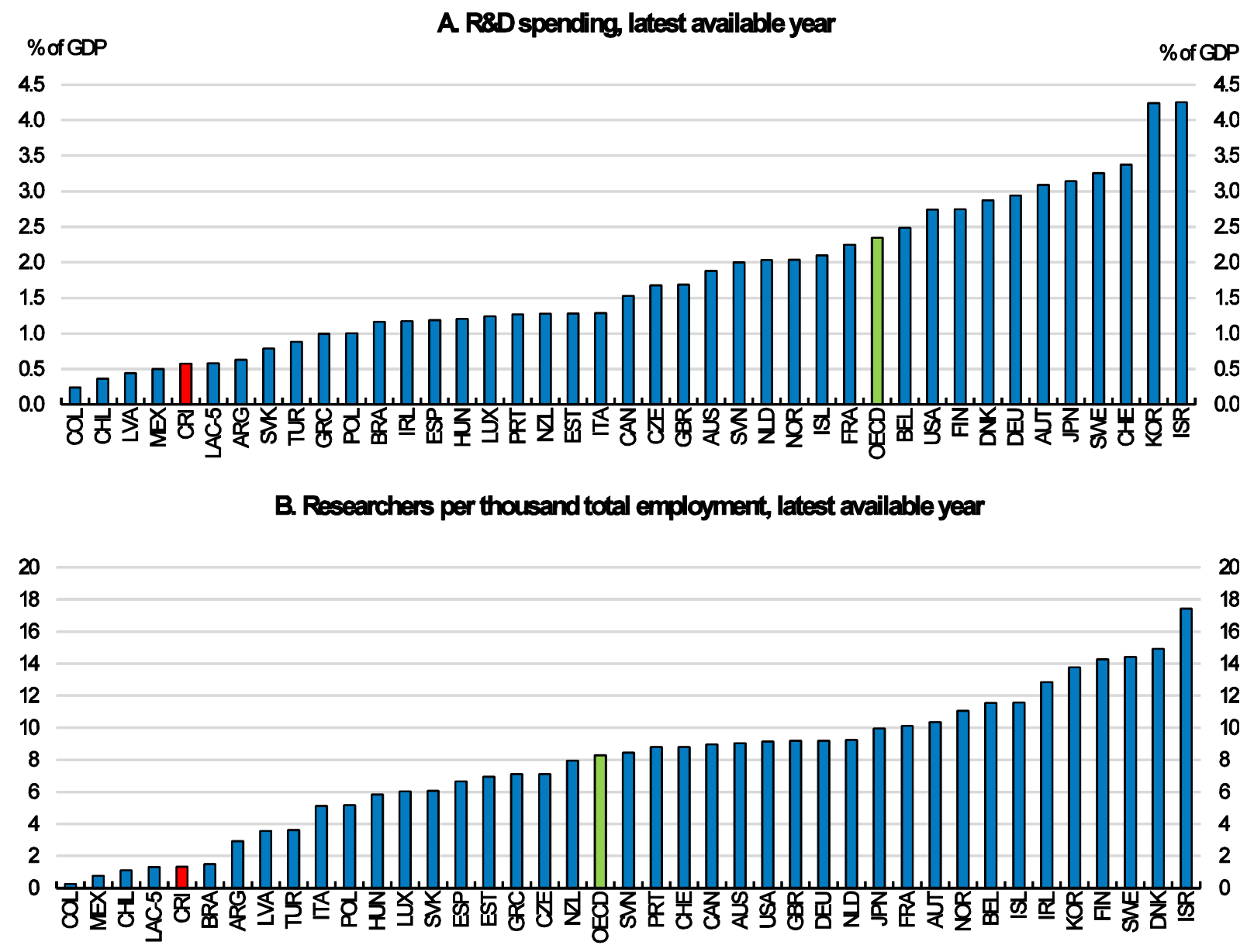

Note: R\&D spending is measured as gross domestic expenditure on research and development. OECD is a simple average of OECD member countries. LAC-5 is a simple average of Argentina, Brazil, Chile, Colombia and Mexico.

Source: OECD, Main Science and Technology Indicators Database. UNESCO Institute for Statistics. 
Figure 20. A large and increasing share of $R \& D$ is financed by the government

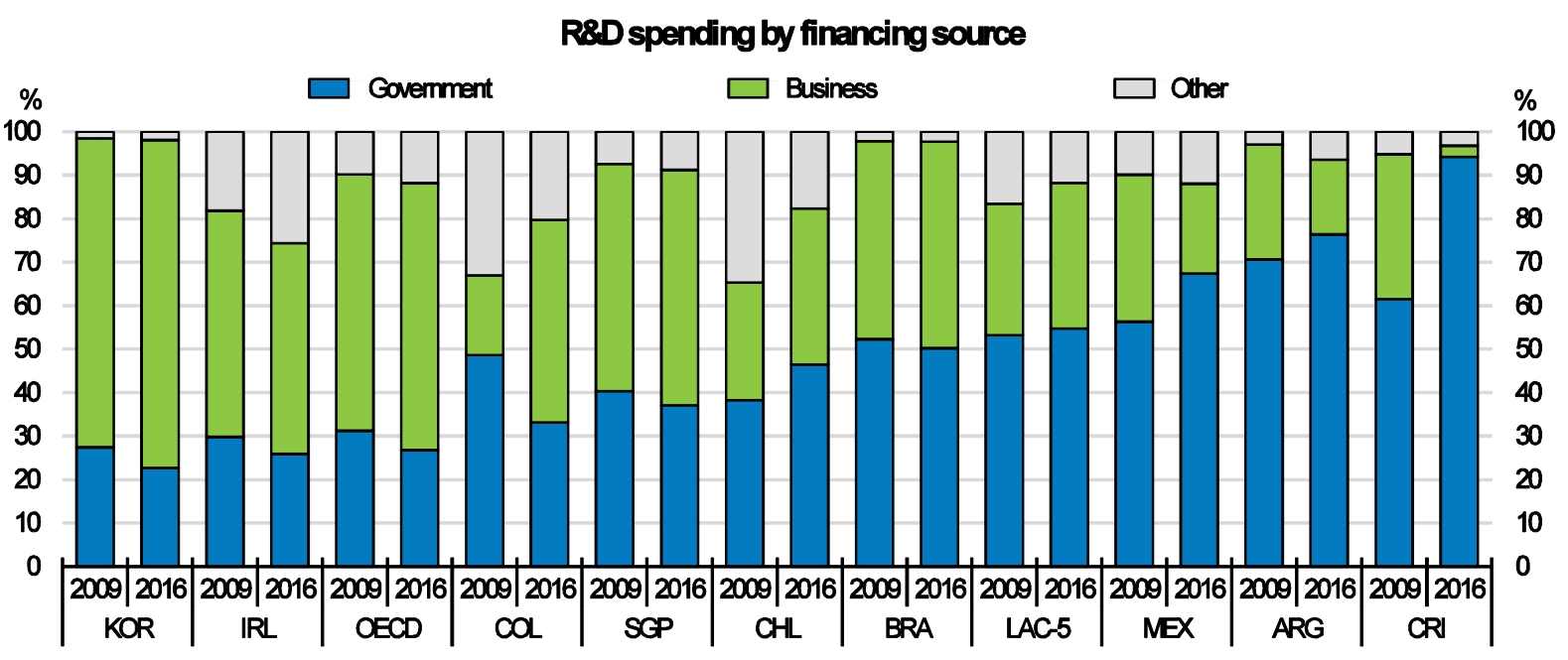

Note: R\&D spending is measured as gross domestic expenditure on research and development. OECD is a simple average of OECD member countries. LAC-5 is a simple average of Argentina, Brazil, Chile, Colombia and Mexico. First year of reference is 2009 except for Argentina (2008). Second year of reference is 2016 except for Argentina (2015), Ireland (2015), OECD (2015), Brazil (2015), Colombia (2015), Costa Rica (2014) and Singapore (2014).

Source: OECD Main Science and Technology indicators (database). Red de Indicadores de Ciencia y Tecnología RICYT, Indicadores de Insumo.

\section{Strengthening coordination to increase firm linkages and the contribution of public research to innovation}

The effectiveness of Costa Rica's innovation policy is hindered by fragmentation in policy execution and institutional settings, limiting coherence and direction in research and innovation policy by the Ministry of Science, Technology and Telecommunications (MICITT) and its agencies (OECD, 2017e). This fragmentation affects the delivery of business assistance programmes aimed at boosting innovation in local companies and deepening their links with foreign affiliates. These programmes include PROPYME managed by MICITT to promote innovation and technological development in SMEs through grants - and Linkages (formerly Costa Rica Provee) - managed by PROCOMER to improve linkages between foreign and domestic companies by matching suppliers with buyers. Policy evaluation suggests that these programmes improve business performance, resulting in greater employment, profitability and exports, with stronger effects for firms enrolled in both programmes (Monge González et al. 2010; Monge-González and Rodríguez-Álvarez, 2013).

Given these positive results, the 2016 Economic Assessment recommended scaling up PROPYME and Linkages and improving their coordination, as well as establishing a onestop agency for related business assistance services (OECD, 2016b). A bill to create a new agency, FOMPRODUCE, to concentrate funds and responsibilities relating to firm innovation and development in one entity is consistent with this (Bill 19.822). However this proposal has stalled, although work continues to address stakeholder concerns and garner support for the bill.

The legal framework for intellectual property rights (IPR) in Costa Rica complies with international standards, however enforcement is weak, particularly in relation to copyright piracy and trademark counterfeiting, which may be discouraging the creation 
and diffusion of knowledge (OECD, 2016b). In order to address this concern, the Costa Rican authorities have taken steps to strengthen the prosecution of IPR infringements and improve border control measures, including through the law to enhance the fight against smuggling (Law 9328) that came into force in 2016, although its impact remains to be seen (OECD, 2017p).

The high level of university autonomy is another aspect of the lack of a unified and concerted approach in the area of research and innovation. As discussed above in relation to improving education, the OECD has recommended that Costa Rica takes a more unified approach to university funding and that it reforms the FEES funding system by increasing the share of competitive funding to raise the quality of research and to incentivise linkages with the business sector (OECD, 2016b; OECD, 2017e). To date, this recommendation has not progressed due to considerable resistance from stakeholders.

\section{Boosting regional integration through improved trade facilitation}

Costa Rica is well integrated into global value chains (GVCs) from a backward participation perspective, with a share of foreign value added in gross exports that is similar to that of Mexico (Figure 21, Panel A). However, Costa Rica remains below peer countries regarding its forward participation in GVCs - that is, the share of Costa Rican value added embodied in foreign countries' exports is low (Figure 21, Panel B). Costa Rica's backward participation is concentrated in medium-high and high-technology industries (Figure 21, Panel C), while its forward participation is concentrated in services (Figure 21, Panel D). Costa Rica's backward participation is tilted towards the United States (Figure 21, Panel E), while its forward participation is oriented towards Asia, with only a small share of its GVC participation involving Latin American countries (Figure 21, Panel F). This mirrors the more general finding that intra-regional links in Latin America are weak, in contrast to the strong role of regional value chains in Asia, Europe and North America. For example, of the total foreign value added used for producing exports in Latin America, only 9\% was sourced from within the region, compared with 49\% in the EU and 40\% in Southeast Asia (OECD and IDB, 2016). 
Figure 21. Costa Rica is well integrated into GVCs from a backward participation perspective

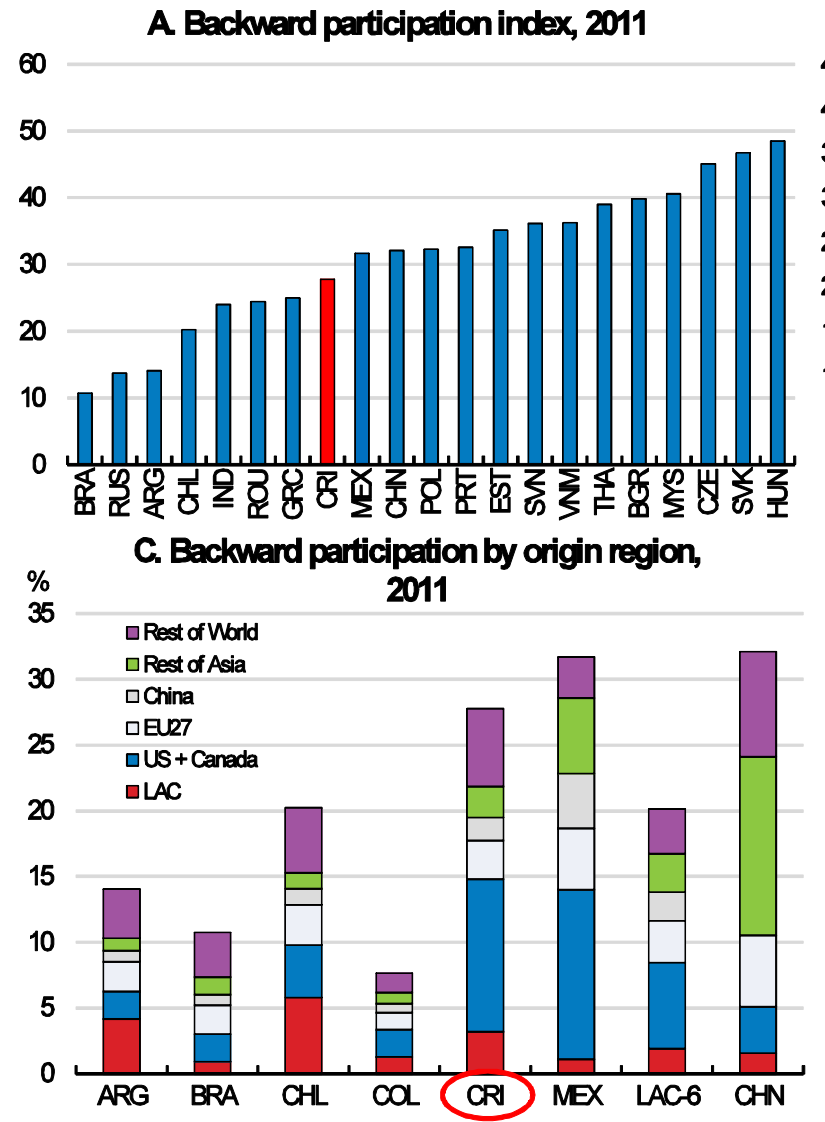

E Forward participation by destination region,

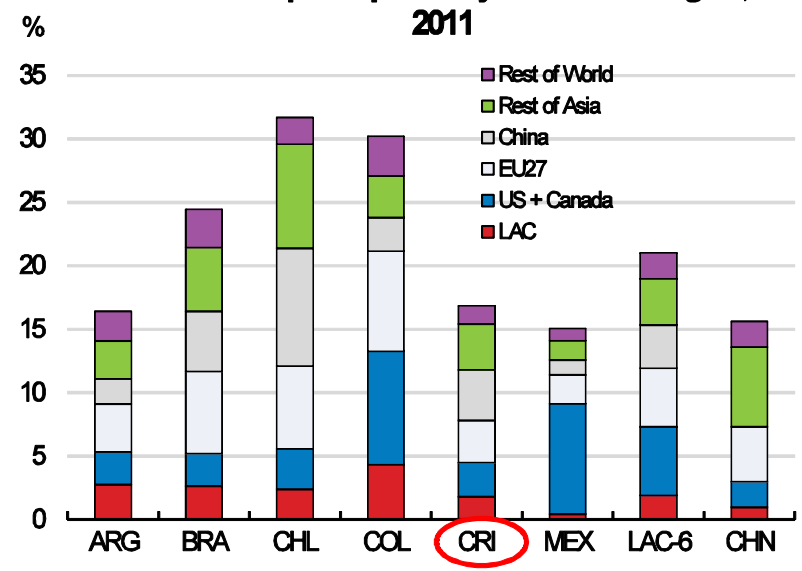

B. Forward participation index, 2011

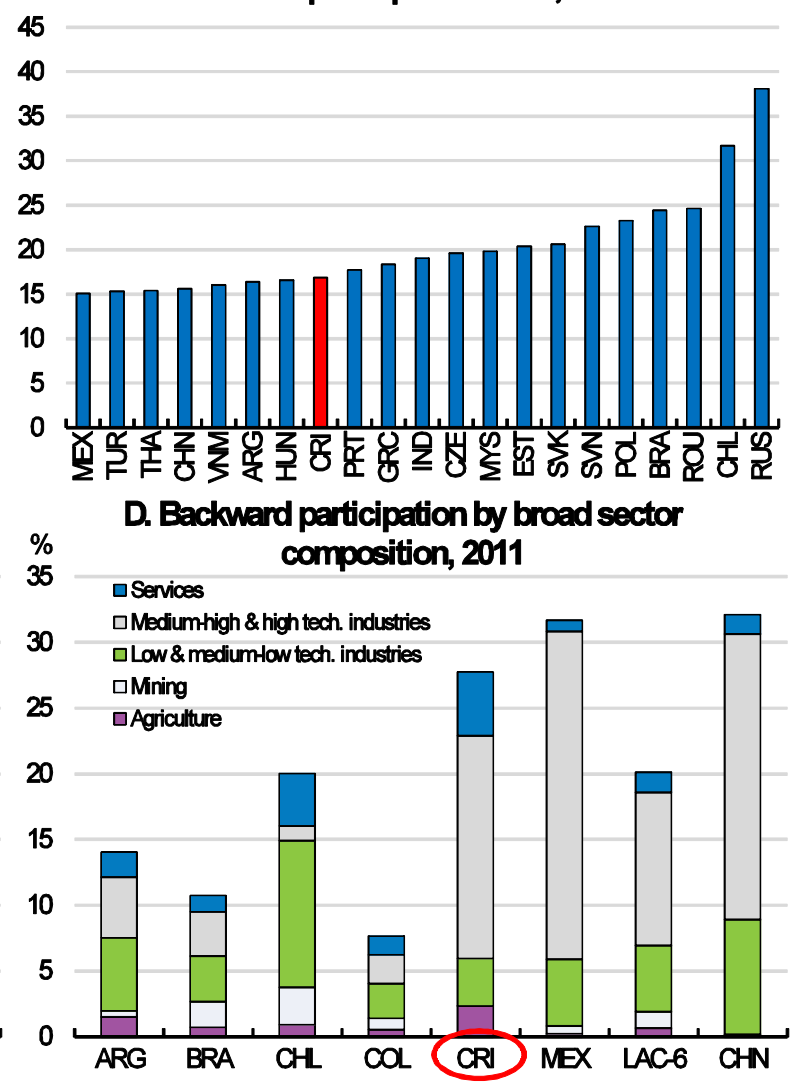

\section{F. Forward participation by broad sector composition, 2011}

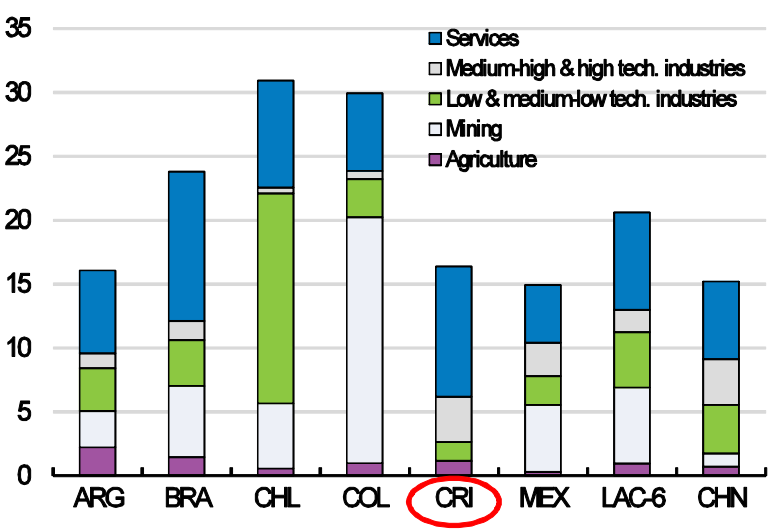

Note: The backward participation index is defined as the share of foreign value added in a country's gross exports. Forward participation is defined as the share of domestic value added embodied in foreign countries' exports. For comparability reasons, most countries included are non-OECD peer countries, such as Brazil, Argentina, Indonesia, Romania, Vietnam, among others. According to the OECD technology classification for industries high tech industries include: Air and spacecraft and related machinery, pharmaceuticals, computer electronic and optical products, medical and dental instruments; medium-high tech industries refer to products such as motor vehicles, machinery and equipment, chemicals and chemical products, electrical equipment. LAC-6 refers to Argentina, Brazil, Chile, Colombia, Mexico and Peru.

Source: OECD-WTO Trade in Value Added database. 
Recognising the potential to boost intra-regional trade, a law to create a National Council of Trade Facilitation (Consejo Nacional de Facilitación del Comercio, CONAFAC) was passed in April 2017 (Law 9430), and the Council is expected to be fully operational in 2018. The Council has 12 members: seven vice-ministers whose functions relate to border control and five private-sector representatives. CONAFAC's decisions are binding on the relevant government agencies. It aims to reduce the transaction costs and increase the security of cross-border commercial operations. CONAFAC is responsible for the implementation of free trade agreements as well as the modernisation and continuous improvement of all infrastructure relating to the cross-border movement of goods and people (it does not cover services). Examples of planned initiatives include standardisation and digitalisation of land border crossings in Central America as delays at border crossings are a significant contributor to slow land transport times.

According to the OECD's Trade Facilitation Indicators, Costa Rica's performance exceeds that of other countries in the region but remains below the OECD average. CONAFAC has the potential to improve Costa Rica's performance in a number of dimensions, including simplifying and harmonising documents, automation and streamlining of border procedures, and improving coordination of the relevant national agencies. Relatively modest changes in this area could have a significant impact on growth - for example, communicating regulations in an accessible manner at the international level could boost GDP per capita growth by $0.9 \%$ (Box 1 ).

\section{Addressing transport infrastructure gaps}

Costa Rica has significant infrastructure gaps, particularly in transport infrastructure, which are hindering productivity and environmentally-sustainable growth, as well as negatively affecting the population's well-being (Estado de la Nación, 2016; OECD and IDB, 2016; OECD, 2017d). Costa Rica ranks below the Latin American average for the perceived quality of roads, ports and railroads, but above the average for airports (Figure 22). These perceptions are supported by technical assessments, with only half of the roads considered to be in good condition (LANAMME, 2017). The potential gains from improving the quality and quantity of the road network are significant. Estimates suggest that GDP growth rates could increase by 0.14 percentage points if the quality of Costa Rica's roads was increased to the median for Latin American countries (Lanau, 2017; Box 1).

The low quality of transport infrastructure reflects consistent underspending in the past, deficient strategic planning, and poor project management and execution. Spending on infrastructure has been lower than the OECD average despite greater needs. The government is aware of the spending shortfall and the National Transport Plan 2011-35 projects annual infrastructure spending needs of almost 4\% of GDP to 2035 (MOPT, 2011; OECD, 2016b). However, spending has been irregular as there is no multi-year budgeting process, making infrastructure investment vulnerable to cuts particularly in the context of limited fiscal space and a high level of earmarking for other areas of public spending (MOPT, 2011; OECD, 2016b).

Strategic planning and project management are also weak. This is typified by the wellpublicised problems with the Alfredo González Flores Bridge. The bridge is part of the highway connecting San José with Alajuela province, and is the major route between the capital city and Juan Santamaría International Airport and carries about 90000 cars a day. 
Yet, despite its importance and attempts by three successive governments to repair and expand it since 2009, this work was only completed in March 2017.

Another example is the need for a mass rapid transit system for the Great Metropolitan Area of San José (GMA) to reduce congestion and pollution, promote competition among firms and maximise the benefits of agglomeration economies (Ahrend, 2015; Atkin and Donaldson, 2015; Hsieh and Moretti, 2015). Despite long-standing plans, little progress has been made. Most recently, this planning has involved the creation of a committee consisting of representatives from the 21 GMA municipalities, the Ministry of Housing and Human Settlement, Ministry of Public Works (MOPT), and the Ministry of the Environment and Energy (MINAE). However, past planning exercises have failed to lead to concrete action, and it is not clear whether implementing the latest plan will prove more successful than past attempts, once again highlighting the issues arising from the high degree of institutional fragmentation.

Figure 22. Perceived quality of transport infrastructure is low

A. Roads

Perceived quality of infrastructure from 1 (worst) to 7 (best)

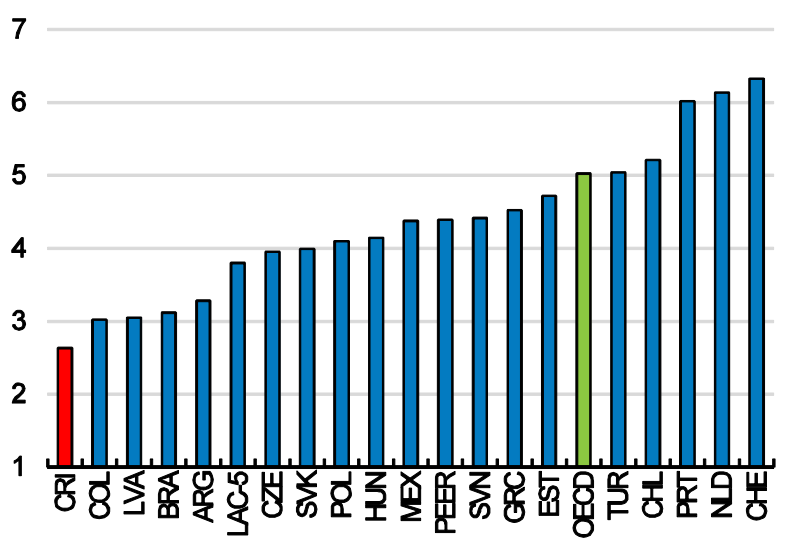

C. Railroad

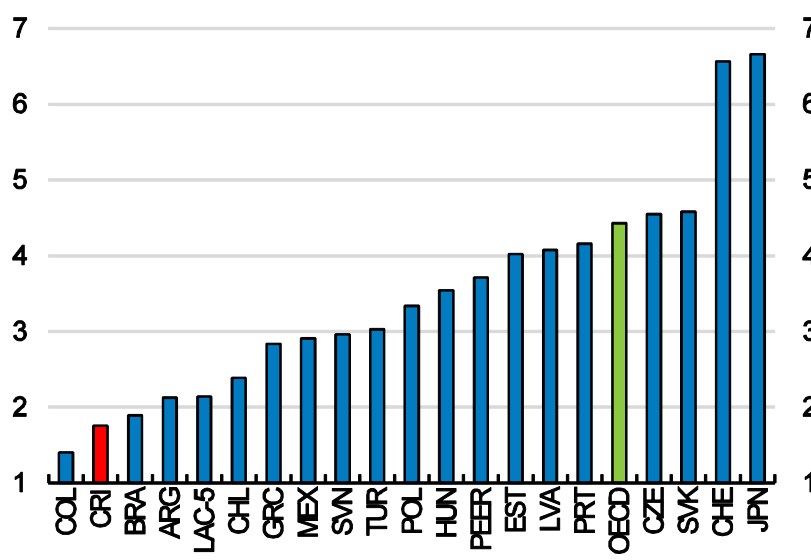

B. Ports

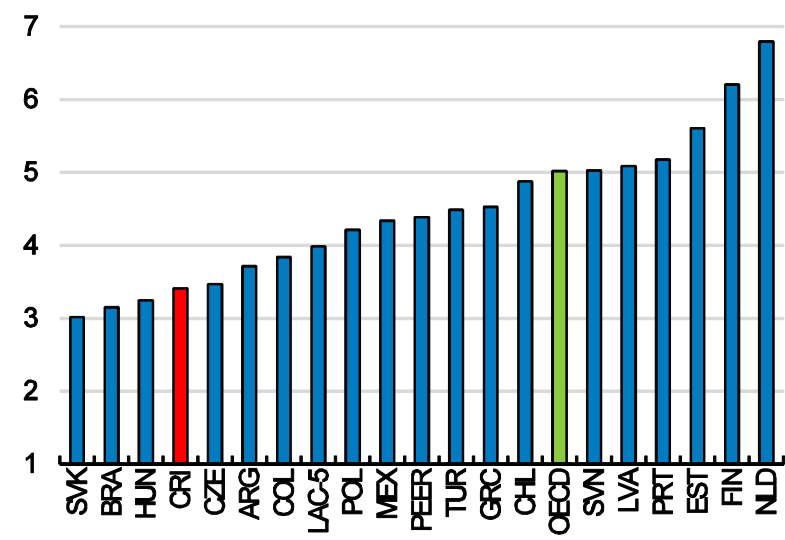

D. Air transport

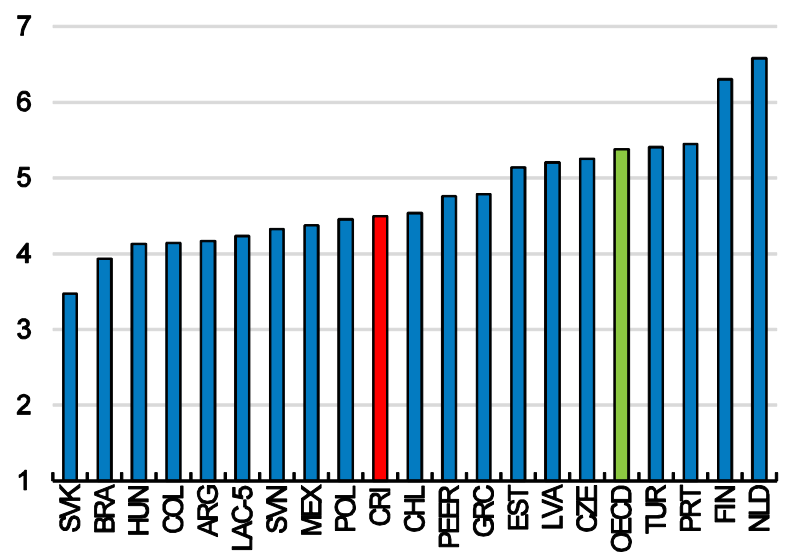

Note: OECD is a simple average of OECD member countries; LAC-5 is a simple average of Argentina, Brazil, Chile, Colombia and Mexico; PEER is a simple average of the 10 non-Latin American OECD countries with the lowest GDP per capita. Road, port and air transport measures use the 2017-2018 Global Competitiveness Index edition. Rail uses 2016-2017 edition due to data availability for Costa Rica.

Source: World Economic Forum, The Global Competitiveness Index Historical Dataset 2007- 


\section{Streamlining the institutional framework for transport infrastructure investment}

The transport infrastructure planning processes are highly fragmented, involving several different ministries and government agencies with unclear and overlapping mandates, resulting in a lack of coherence and contributing to project delays (Pisu and Villalobos, 2016). The OECD has recommended that the institutional and legal framework of publicwork agencies be streamlined and that a more strategic approach to long-term planning be taken, including by establishing a project pipeline to increase certainty (OECD, 2016b).

Costa Rica acknowledges these issues and some efforts have been made to improve the situation. A law to improve the financing and investment of the public institution responsible for train infrastructure (INCOFER) has been passed, a necessary but modest step towards the government's goal of establishing a rapid mass transport system for the GMA of San José. A bill to strengthen the Ministry of Public Works' (MOPT) stewardship of the sector and create a new, strengthened coordinating body for road infrastructure (the National Institute of Road Instructure) was proposed in 2016 but lacks political support (Bill 19.900). However, even if these measures are implemented, fragmentation issues will still be significant.

A necessary condition for a successful infrastructure programme is appropriate strategic planning that sets a long-term vision and prioritises investment (OECD, 2017q). While Costa Rica established the National Transport Plan 2011-2035 in response to the need to develop a long-term strategic view and investment priorities, it serves primarily as guidance for institutions involved in transport infrastructure and lacks legal enforcement mechanisms (Pisu and Villalobos, 2016). Different autonomous bodies are responsible for the numerous aspects of transport infrastructure and there are no mechanisms to coordinate and align incentives. For example, in road transport, the National Road Council (CONAVI) is responsible for extending and maintaining the national road network, municipalities are in charge of local roads, and the Public Transportation Council (CTP) is responsible for public road transportation (i.e. taxis, buses and coaches). The lack of coordination and strict budgetary separation, and in some cases (notably public transport) the absence of a budgetary line, means that there is no mechanism for making strategic trade-offs between different transport modes, for example, decisions such as whether to invest in public transport as an alternative to building more roads.

Coordination and accountability would be greatly improved by clarifying the mandates of the different agencies and granting authority and control of infrastructure management to a single institution. This lead agency could also be charged with long-term strategic planning and the development of a clear project pipeline, with project selection and prioritisation based on cost-benefit analysis (OECD, 2016b; Pisu and Villalobos, 2016; OECD, 2017q). Currently, these steps are overlooked, with more emphasis placed on concessions and project financing, which, while important, are secondary considerations to systematic prioritisation. Indeed, to ensure that projects are prioritised according to cost-effectiveness criteria, the OECD Principles for the Public Governance of PublicPrivate Partnerships highlight that best practice involves separating the project selection and delivery mode decisions (OECD, 2012b). After the prioritisation process has taken place, selected projects should then be evaluated on a case-by-case basis to identify the most appropriate delivery mode (e.g. PPP or direct public provision) (OECD, 2017q). 


\section{Reforming institutional settings to improve the governance of private sector investment}

Costa Rica's National Transport Plan 2011-35 envisages that a third of the 4\% of GDP spending on transport infrastructure will come from private sector investment (MOPT, 2011). However, Costa Rica has relatively little experience with PPPs and private involvement in infrastructure projects has been low and fraught. There have been only four PPP projects since the General Concession Law regulating private participation was passed in 1998, and these suffered from delays of up to 11 years before construction even began (OECD 2016b; Pisu and Villalobos, 2016; OECD, 2017r).

While there are a number of legitimate reasons for seeking the involvement of the private sector in the provision of infrastructure investment, PPPs are sometimes used inappropriately to disguise pressure on public finances. In such cases, investment decisions - by precluding appropriate alternative investment arrangements - will lead to suboptimal outcomes. This underscores the importance of separating the decision to invest in a project from the decision about how to procure and finance the investment. Moreover, the use of PPPs should be accompanied by proper and transparent assessment of their expected long-term impact on public finances (Araújo and Sutherland, 2010; OECD, 2012b). A stark example occurred in Hungary with major PPPs for motorways recorded off-budget in 2005 and 2006, despite the partnership involving a state-owned enterprise (Araújo and Sutherland, 2010).

Private participation in infrastructure in Costa Rica is governed by a fragmented legal framework (OECD, 2017q). Given the complexity of PPPs, the OECD guidelines highlight the importance of a robust governance structure where relevant agencies have a clear mandate and accountability (OECD, 2012b). In response to these concerns, Costa Rica is in the process of developing a new framework for public-private initiatives. In 2016, a public policy for PPPs was formulated and a decree was issued to regulate PPP projects. While positive, greater clarity is needed about how this new framework will be implemented within the current institutional and legal settings (OECD, 2017r). For example, the role of the new regulation in relation to the existing concessions legislation (Law 7762) which has been in place since 1998 should be clarified.

The OECD has also recommended that the National Concession Council (CNC) - which is responsible for promoting and managing concession projects - be moved from the Ministry of Public Works to the Ministry of Finance, which is better placed to account for the contingent liabilities arising from private-sector participation (OECD, 2016b). The current arrangement may also create a bias against private participation in infrastructure because the Ministry of Public Works also promotes publicly-funded infrastructure projects that can be in direct competition with privately funded ones. This recommendation has not progressed, but a PPP unit has been created within the Ministry of Finance. Consistent with recommendations to align practices with the OECD Principles for the Public Governance of Public-Private Partnerships, the unit will manage the public financing issues relating to PPPs, including the associated contingent liabilities, and has also developed a number of guidelines and project assessment criteria and training on their use is underway (OECD, 2012; Pisu and Villalobos, 2016; OECD, 2017r). While it is positive that the PPP unit is implementing best-practice guidelines, the addition of another agency has the potential to further contribute to the institutional coordination issues. PPPs involve a host of issues such as selecting the most efficient bidder; designing contracts to effectively allocate risks, mitigating hold-ups and minimising costly renegotiations; the ongoing management and monitoring of PPP 
contracts; and accounting for the fiscal impact of PPPs through consideration and reporting of contingent liabilities (Araújo and Sutherland, 2010). In practice, it appears that the two entities are working together, with the PPP unit focussing on public financing issues and the $\mathrm{CNC}$ remaining responsible for the contract management and technical aspects. However, additional efforts are needed to clarify the roles of the two entities and establish mechanisms to align and coordinate their work (OECD, 2017r). More generally, these arrangements should continue to be monitored as they remain untested in practice as no PPP has taken place under the new regulatory and institutional arrangements. 
Box 4. Recommendations for structural policies to boost productivity and inclusion

\section{Making labour markets more inclusive}

- Continue moving to a smaller number of minimum wages.

- Implement a comprehensive plan to reduce informality, including greater enforcement of obligations to pay contributions.

- Increase the supply of publicly-funded childcare services. Classify all spending on early childhood education and care under the constitutionally-mandated spending on education.

- Strengthen the enforcement of labour regulations by granting inspectors the right to impose sanctions directly and ensuring sanctions are large enough to act as a deterrent.

\section{Enhancing the quality and efficiency of the education system}

- Establish better educational outcomes as the main policy target, instead of a focus on spending, and develop performance indicators.

- Rebalance education spending towards early childhood and secondary education. Strengthen targeted support for at-risk students, and teachers' training.

- Establish and enforce a comprehensive set of minimum standards for all early childhood care centres.

- Strengthen the national assessment system to provide information at the system, school and student level.

- Monitor the results of the dual education pilot programme and consider options for developing vocational educational further, in close conjunction with employers.

- Reform the secondary school assessment system (Bachillerato) to better recognise partial achievement and increase flexibility.

- Increase the share of competitive funding for public universities, based on performance measures such as the labour-market relevance of qualifications and research outcomes.

\section{Strengthening competition}

- Adopt and implement the bill reinforcing the powers, independence and funding of the competition commission.

- Continue implementation of the action plan to increase consistency with the OECD Guidelines on Corporate Governance of State-Owned Enterprises.

- Continue with the planned 25 sector studies evaluating the exemption from competition and eliminate unjustified exemptions.

- Open entry to FinTech start-ups, with appropriate regulation. 
- Establish a one-stop-shop for business registration and licensing. Introduce performance targets. Continue to improve the insolvency regime and trade facilitation.

- Approve and implement the proposal to institutionalise the Presidential Council on competitiveness, Innovation and Human Talent, unify its three sub-councils and strengthen its technical secretariat.

- Create a one-stop shop for government business assistance services.

\section{Addressing transport infrastructure gaps}

- Improve coordination among the different public-works bodies by clarifying mandates and granting overall control to a single lead agency. Prioritise projects based on cost-benefit analysis.

- Clarify the mandates of the National Concessions Council (CNC) and the PPP unit and introduce mechanisms to align and coordinate the work of the two entities. 


\section{References}

Adalet McGowan, M. and D. Andrews (2015), "Skill mismatch and public policy in OECD countries", OECD Economics Department Working Papers, No. 1210, OECD Publishing, Paris, http://dx.doi.org/10.1787/5js1pzw9lnwk-en.

Adalet McGowan, M., D. Andrews and V. Millot (2017), "Insolvency regimes, zombie firms and capital reallocation", OECD Economics Department Working Papers, No. 1399, OECD Publishing, Paris, http://dx.doi.org/10.1787/5a16beda-en.

Aghion, P. and R. Griffith (2005), Competition and Growth: Reconciling Theory and Evidence, MIT Press, Cambridge MA.

Ahrend, R. et al. (2017), "What makes cities more productive? Evidence from five OECD countries on the role of urban governance", Journal of Regional Science, Vol. 57/3, pp. 385-410.

Alfaro, A. and J. Garita (2018). "Misallocation and productivity in Costa Rica", in OECD Economic Survey of Costa Rica 2018: Research findings on productivity from firm-level, trade and sectoral data, OECD Publishing, Paris, forthcoming.

Alfaro, A. and A. Quesada (2015), "Transformación estructural y productividad sectorial en Costa Rica”, Documento de Investigación, No. 07-2015, Banco Central de Costa Rica, San José, http://www.bccr.fi.cr/investigacioneseconomicas/crecimientoeconomico/Transformacestructura lyproductividadsectorialenCR.pdf.

Almond, D. and J. Currie (2011), "Human capital development before age five", Handbook of Labor Economics, Vol. 4, Part B, pp. 1315-1486.

Araújo, S. and S. Guichard (2018), "Restoring fiscal sustainability and setting the basis for a more growth friendly and inclusive policy in Costa Rica", OECD Economics Department Working Papers, No. 1484, OECD Publishing, Paris.

Araújo, S., A. Linares and T. Chalaux (2018), "The road to development: Identifying upscaling opportunities for Costa Rica", OECD Economics Department Working Paper, forthcoming.

Araújo, S., T. Chalaux and D. Haugh (2018), "Who's in your export market? The changing pattern of world trade in the age of GVCs", OECD Economics Department Working Paper, forthcoming.

Araújo, S. and D. Sutherland (2010), "Public-private partnerships and investment in infrastructure", OECD Economics Department Working Papers, No. 803, OECD Publishing, Paris, http://dx.doi.org/10.1787/5km7jf6q8f0t-en.

Atkin, D. and D. Donaldson (2015), "Who's getting globalized? The size and implications of intranational trade costs", NBER Working Paper, No. 21439, National Bureau of Economic Research, Cambridge MA, http://dx.doi.org/10.3386/w21439.

Banco Central de Costa Rica (2016), Programa Macroeconómico 2017-2018, Banco Central de Costa Rica, San José, http://www.bccr.fi.cr/noticias/historico/2016/noticia_programa_2017_18.html. 
Bell, D.N.F. and D.G. Blanchflower (2011), "Young people and the Great Recession", Oxford Review of Economic Policy, Vol. 27/2, pp. 241-267.

Bourlès, R. et al.(2013), "Do product market regulations in upstream sectors curb productivity growth? Panel data evidence from OECD countries", Review of Economics and Statistics, Vol. 95/5, pp. $1750-1768$.

Braguinsky, S., L.G. Branstetter and A. Regateiro (2011), "The incredible shrinking Portuguese firm", NBER Working Paper, No. 17265, http://www.nber.org/papers/w17265.

Broecke, S., A. Forti and M. Vandeweyer (2017), "The effect of minimum wages on employment in emerging economies: A survey and meta-analysis", Oxford Development Studies, Vol. 45/3, pp. 366-391.

Busso, M., M. Fazio and S. Levy (2012), "(In)formal and (un)productive: The productivity costs of excessive informality in Mexico", IDB Working Paper Series, No. IDB-WP-341, IDB, Washington DC, https://publications.iadb.org/bitstream/handle/11319/4047/\%28In\%29Formal\%20and\%20\%28 Un\%29Productive\%3A\%20The\%20Productivity\%20Costs\%20of\%20Excessive\%20Informalit y\%20in\%20Mexico.pdf?sequence $=1$.

Carrillo, P., N. Gandelman, V. Robano (2014), "Sticky floors and glass ceilings in Latin America", Journal of Economic Inequality, Vol. 12, pp. 339361. http://dx.doi.org/10.1007/s10888-013-9258-3.

Conway, P., D. de Rosa, G. Nicoletti and F. Steiner (2006), "Regulation, competition and productivity convergence", OECD Economics Department Working Papers, No. 509, OECD Publishing, Paris, http://dx.doi.org/10.1787/431383770805.

Cornick, J. and A. Trejos (2016), "Building public capabilities for productive development policies: Costa Rican case studies", IDB Working Paper, No. IDB-WP-686, IDB. https://publications.iadb.org/handle/11319/8017.

Cuberes, D. and M. Teignier (2016), "Aggregate effects of gender gaps in the labor market: A quantitative estimate", Journal of Human Capital, Vol. 10/1, pp.1-32.

Cunha, F. et al. (2006), "Interpreting the evidence on life cycle skill formation" in Hanushek, E. and F. Welch (eds.), Handbook of the Economics of Education, Elsevier B.V., Amsterdam.

Denk, O. (2016), "How do product market regulations affect workers?: Evidence from the network industries", OECD Economics Department Working Papers, No. 1349, OECD Publishing, Paris, http://dx.doi.org/10.1787/5167d865-en

Égert, B. (2017), "The quantification of structural reforms: Extending the framework to emerging market economies", OECD Economics Department Working Papers, No. 1442, OECD Publishing, Paris, http://dx.doi.org/10.1787/f0a6fdcb-en.

Égert, B. and P. Gal (2017), "The quantification of structural reforms in OECD countries: A new framework", OECD Economics Department Working Papers, No. 1354, OECD Publishing, Paris. http://dx.doi.org/10.1787/2d887027-en.

Ennis, S., P. Gonzaga and C. Pike (2017), "Inequality: A hidden cost of market power", www.oecd.org/daf/competition/inequality-a-hidden-cost-of-market-power.htm.

Escobar, O. and L. Meehan (2018), "Setting the scene: An overview of Costa Rica's productivity performance", in OECD Economic Survey of Costa Rica 2018: Research findings on productivity from firm-level, trade and sectoral data, OECD Publishing, Paris, forthcoming. 
Estado de la Nación (2017), "Estado de la nación en desarrollo humano sostenible", Programa Estado de la Nación, San José, Costa Rica, http://estadonacion.or.cr/2017/.

Estado de la Nación (2016), "Estado de la nación en desarrollo humano sostenible", Programa Estado de la Nación, San José, Costa Rica, , https://www.estadonacion.or.cr/22/.

Estado de la Nación (2015), "Quinto informe estado de la educación 2015”, Estado de la Nación, San José, http://www.estadonacion.or.cr/educacion2015/index.html.

Estado de la Nación (2014), "Estado de la nación en desarrollo humano sostenible", Estado de la Nación, San José, https://www.estadonacion.or.cr/20/.

European Commission and OECD (2015), Policy Brief on Informal Entrepreneurship, Publications Office of the European Union, Luxembourg.

Fernández, C. and L. Villar (2016), “A taxonomy of Colombia's informal labor market”, Fedesarrollo Working Paper, No. 73. http://www.repository.fedesarrollo.org.co/bitstream/handle/11445/3304/WP_2016_No_73.pdf? sequence $=1 \&$ is Allowed $=\mathrm{y}$.

Ferreira, F., C. Lakner, M. Lugo and B. Özler (2014), "Inequality of opportunity and economic growth: How much can cross-country regressions really tell us?", Review of Income and Wealth, http://dx.doi.org/10.1111/roiw.12311.

Filho, F. and F. Veloso (2016), Causas e Consequências da Informalidade no Brasil, Elsevier, FGVIBRE, Rio de Janeiro.

Gal, P. and A. Theising (2015), "The macroeconomic impact of structural policies on labour market outcomes in OECD countries", OECD Economics Department Working Paper, No. 1271, OECD Publishing, Paris, http://dx.doi.org/10.1787/5jrqc6t8ktjf-en.

Garicano, L., C. Lelarge and J. Van Reenen (2016), "Firm size distortions and the productivity distribution: Evidence from France", American Economic Review, Vol. 2016/11, pp. 34393479 .

Gindling, T.H. and K. Terrell (2007). "The effects of multiple minimum wages throughout the labor market: The case of Costa Rica", Labour Economics, Vol. 14, pp. 485-511.

Gindling, T.H. and J.D. Trejos (2010). "Improving compliance with legal minimum wages in Costa Rica". https://economics.umbc.edu/files/2014/09/wp_10_127.pdf.

González Pandiella, A. and M. Gabriel (2017), "Deconstructing income inequality in Costa Rica: An income source decomposition approach", OECD Economics Department Working Papers, No. 1377, OECD Publishing, Paris, http://dx.doi.org/10.1787/77759015-en.

Hoeller, P. et al (2012), "Less income inequality and more growth - are they compatible? Part 1. Mapping income inequality across the OECD", OECD Economics Department Working Papers, No. 924, OECD Publishing, Paris, http://dx.doi.org/10.1787/5k9h297wxbnr-en.

Hsieh, C. (2015), "Policies for productivity growth", OECD Productivity Working Papers, No. 3, OECD Publishing, Paris, http://dx.doi.org/10.1787/5jrp1f5rddtc-en.

Hsieh, C. and P. Klenow (2009), "Misallocation and manufacturing TFP in China and India", Quarterly Journal of Economics, Vol. 124/4, pp. 1403-1448.

Hsieh, C. and E. Moretti (2015), "Why do cities matter? Local growth and aggregate growth", NBER Working Papers, No. 21154, National Bureau of Economic Research, Cambridge, MA. 
ILO (2014), "Policies for the formalization of micro and small enterprises in Costa Rica", Notes on Policies for the Formalization of Micro and Small Enterprises, ILO, http://www.ilo.org/empent/whatsnew/WCMS_318212/lang--en/index.htm.

ILO (2013), "The formal and informal sectors in Colombia: Country case study on labour market segmentation", Employment Working Paper, No. 146, ILO, Geneva, http://www.ilo.org/wcmsp5/groups/public/---ed emp/--ifp_skills/documents/publication/wcms_232495.pdf.

IMF (2017), "Mexico: Selected issues and analytical notes", IMF Country Report, No. 17/347, IMF, Washington DC.

Jiménez, R. (2014), Educación Pública en Costa Rica: Políticas, Resultado y Gasto, No. 6, Academia de Centroamérica, San José.

LANAMME (2017), "Informe de Evaluación de la Red Vial Nacional Pavimentada de Costa Rica Años 2016-2017”, San José, http://www.lanamme.ucr.ac.cr/index.php/home/evaluaci\%C3\%B3n-redvial-nacional-rv/informes-evaluaci\%C3\%B3n-red-vial-nacional/informe-rvn-2016-2017.html.

Lanau, S. (2017) "The growth return of infrastructure in Latin America". IMF Working Paper, No. WP/17/35, https://www.imf.org/en/Publications/WP/Issues/2017/02/14/The-Growth-Return-ofInfrastructure-in-Latin-America-44663.

López-Calva, L.F. and N. Lustig (2010), Declining Inequality in Latin America: A Decade of Progress?, Brookings Institution Press.

Lustig, N. (2017), "El impacto del sistema tributario y el gasto social en la distribución del ingreso y la pobreza en Améica Latina: Una aplicación del marco metodológico del proyecto Compromiso Con La Equidad (CEQ)", Documento de Trabajo, No. 62, http://www.commitmentoequity.org/wpcontent/uploads/2017/08/CEQ WP62 Lustig July06 2017.pdf.

Mateo-Diaz, M. and L. Rodriguez-Chamussy (2013), "Childcare and women's labor participation: Evidence for Latin America and the Caribbean", Inter-American Development Bank Technical Note, No. IDB-TN-586, https://publications.iadb.org/handle/11319/6493?localeattribute $=$ en $\&$ locale-attribute $=$ es.

MICITT (2016), “Indicadores nacionales de ciencia, tecnología e innovación Costa Rica 2014”, Ministry of Science, Technology and Telecommunications, San José, www.conicit.go.cr/biblioteca/publicaciones/publicacionescyt/otros_documentosCyT/indicadore sCyT-2014.pdf.

MIDEPLAN (2014), "Plan Nacional de Desarrollo 2015-2018”, Ministerio de Planificación Nacional y Política Económica, San José.

Monge-González, R. (2016), "Innovation, productivity, and growth in Costa Rica: Challenges and opportunities", Technical Note, No. IDB-TN-920, IDB, Washington DC, https://publications.iadb.org/handle/11319/7376.

Monge-González, R., L. Rivera and J. Rosales-Tijerino (2010) "Productive development policies in Costa Rica: Market failures, government failures, and policy outcomes", IDB Working paper Series. No. IDB-WP-157.

Monge-González, R. and J.A. Rodríguez-Álvarez (2013), "Impact evaluation of innovation and linkage development programs in Costa Rica: The cases of PROPYME and CR Provee", IDB Working Paper Series, No. IDB-WP-461, Washington DC. 
Monteiro, G. et al. (2017), "Product markets deregulation: A more productive, more efficient and more resilient economy?", OECD Productivity Working Papers, No. 9, OECD Publishing, Paris, http://dx.doi.org/10.1787/86cc3b5e-en.

MOPT (2011), Plan Nacional de Transportes 2011-2035, Ministerio de Obras Públicas y Transportes, San José.

Morales, L. and C. Medina (2017), "Assessing the effect of payroll taxes on formal employment: The case of the 2012 tax reform in Colombia", Economía, Vol. 18/1, pp. 75-124.

Nicoletti, G. and S. Scarpetta (2003), "Regulation, Productivity and Growth: OECD Evidence", OECD Economics Department Working Papers, No. 347, OECD Publishing, Paris, http://dx.doi.org/10.1787/078677503357.

OECD (2017a), OECD Reviews of Health Systems: Costa Rica, OECD Publishing, Paris, http://dx.doi.org/10.1787/9789264281653-en.

OECD (2017b), OECD Reviews of Labour Market and Social Policies: Costa Rica, OECD Reviews of Labour Market and Social Policies, OECD Publishing, Paris, http://dx.doi.org/10.1787/9789264282773-en.

OECD (2017c), Education in Costa Rica, OECD Publishing, Paris. http://dx.doi.org/10.1787/9789264277335-en.

OECD (2017d), Agricultural Policies in Costa Rica, OECD Publishing, Paris, http://dx.doi.org/10.1787/9789264269125-en.

OECD (2017e), OECD Reviews of Innovation Policy: Costa Rica, OECD Publishing, Paris, http://dx.doi.org/10.1787/9789264271654-en.

OECD (2017f), OECD Economic Surveys: Mexico 2017, OECD Publishing, Paris, http://dx.doi.org/10.1787/eco_surveys-mex-2017-en.

OECD (2017g), OECD Tax Policy Reviews: Costa Rica 2017, OECD Publishing Paris, http://dx.doi.org/10.1787/9789264277724-en.

OECD (2017h), OECD Economic Surveys: Argentina 2017: Multi-Dimensional Economic Survey, OECD Publishing, Paris, http://dx.doi.org/10.1787/eco surveys-arg-2017-en.

OECD (2017i), OECD Economic Surveys: Colombia 2017, OECD Publishing, Paris, http://dx.doi.org/10.1787/eco_surveys-col-2017-en.

OECD (2017j), In-Depth Analysis of the Labour Market Relevance and Outcomes of Higher Education Systems: Analytical Framework and Country Practices Report, Enhancing Higher Education System Performance, OECD, Paris.

OECD (2017k), "Secretariat progress note on Costa Rica: State ownership and privatisation practices", Corporate Governance Committee, Directorate for Financial and Enterprise Affairs, OECD internal report prepared for the OECD accession review of Costa Rica.

OECD (20171), "Accession Review of Costa Rica", Insurance and Private Pensions Committee, Directorate for Financial and Enterprise Affairs, OECD internal report prepared for the OECD accession review of Costa Rica.

OECD (2017m), "Corporate Governance Accession Review of Costa Rica", Corporate Governance Committee, Directorate for Financial and Enterprise Affairs, OECD internal report prepared for the OECD accession review of Costa Rica. 
OECD (2017n), "Accession Review of Costa Rica" Committee on Financial Markets, Directorate for Financial and Enterprise Affairs, OECD internal report prepared for the OECD accession review of Costa Rica.

OECD (2017o), OECD Economic Outlook, Volume 2017 Issue 1, OECD Publishing, Paris, http://dx.doi.org/10.1787/eco_outlook-v2017-1-en.

OECD (2017p), “Accession Examination of Costa Rica under the OECD Investment Instruments", Investment Committee, Directorate for Financial and Enterprise Affairs, OECD internal report prepared for the OECD accession review of Costa Rica.

OECD (2017q), Getting Infrastruture Right: A Framework for Better Governance, OECD Publishing, Paris, http://dx.doi.org/10.1787/9789264272453-en.

OECD (2017r), "PGC Accession Assessment Report: Costa Rica", Public Governance Committee, Public Governance and Territorial Development Directorate, OECD internal report prepared for the OECD accession review of Costa Rica.

OECD (2016a), The Productivity-Inclusiveness Nexus: Preliminary version, OECD Publishing, Paris, http://dx.doi.org/10.1787/9789264258303-en.

OECD (2016b), OECD Economic Surveys: Costa Rica 2016, OECD Publishing, Paris, http://dx.doi.org/10.1787/eco_surveys-cri-2016-en.

OECD (2016c), PISA 2015 Results (Volume I): Excellence and Equity in Education, OECD Publishing, Paris, http://dx.doi.org/10.1787/9789264266490-en.

OECD (2016d), Reviews of National Policies for Education: Education in Colombia, OECD Publishing, Paris, http://dx.doi.org/10.1787/9789264250604-en.

OECD (2016e), “Accession Review of Costa Rica”, Competition Committee, Directorate for Financial and Enterprise Affairs, OECD internal report prepared for the OECD accession review of Costa Rica.

OECD (2015a), Costa Rica: Good Governance, from Process to Results, OECD Public Governance Reviews, OECD Publishing, Paris, http://dx.doi.org/10.1787/9789264246997-en.

OECD (2015b), Universal Basic Skills: What Countries Stand to Gain, OECD Publishing, Paris, http://dx.doi.org/10.1787/9789264234833-en.

OECD (2015c), OECD Economic Surveys: Mexico 2015, OECD Publishing, Paris, http://dx.doi.org/10.1787/eco_surveys-mex-2015-en.

OECD (2015d), OECD Employment Outlook 2015, OECD Publishing, Paris, http://dx.doi.org/10.1787/empl_outlook-2015-en.

OECD (2015e), OECD Guidelines on Corporate Governance of State-Owned Enterprises, OECD Publishing, Paris, http://dx.doi.org/10.1787/9789264244160-en

OECD (2013), OECD Economic Surveys: Brazil 2013, OECD Publishing, Paris, http://dx.doi.org/10.1787/eco_surveys-bra-2013-en.

OECD (2012a), Equity and Quality in Education: Supporting Disadvantaged Students and Schools, OECD Publishing, Paris, http://dx.doi.org/10.1787/9789264130852-en.

OECD (2012b), "Recommendation of the Council on Principles for the Public Governance of PublicPrivate Partnerships", OECD, Paris. http://www.oecd.org/gov/budgeting/oecd-principles-forpublic-governance-of-public-private-partnerships.htm. 
OECD (2007), No More Failures: Ten Steps to Equity in Education, OECD Publishing, Paris. http://dx.doi.org/10.1787/9789264032606-en.

OECD/FUNDEVI (2017), Interrelations between Public Policies, Migration and Devleopment in Costa Rica, OECD Development Pathways, OECD Publishing, Paris. http://dx.doi.org/10.1787/9789264278967-en.

OECD and IDB (2016), Boosting Productivity and Inclusive Growth in Latin America, OECD Publishing, Paris, http://www.oecd.org/latinamerica/Boosting_Productivity_Inclusive_Growth.pdf.

Pisu, M. and F. Villalobos (2016), “A bird-eye view of Costa Rica's transport infrastructure”, $O E C D$ Economics Department Working Papers, No. 1323, OECD Publishing, Paris, http://dx.doi.org/10.1787/5jlswbwvwqjf-en.

Ramírez Alfaro, L. (2010), "La informalidad y semiformalidad empresarial en Costa Rica: un acercamiento desde la mirada de personas expertas", Serie Observatorio de MIPYMES, UNED, San José, Costa Rica.

Rodriguez-Clare, A. (2001), “Costa Rica's development strategy based on human capital and technology: How it got there, the impact of Intel, and lessons for other countries", Journal of Human Development, $\mathrm{Vol}$ 2/2, United Nations Development Programme.

Ruhm, C. and J. Waldfogel (2011), "Long-term effects of early childhood care and cducation", IZA Discussion Paper, No. 6149, Bonn.

Sandoval, C., et al (2017), "Employment dynamics in Costa Rica after the global financial crisis", in Business Dynamics and Productivity, OECD Publishing, Paris. http://dx.doi.org/10.1787/9789264269231-en.

Sandoval, C. et al (2018), "FDI productivity spillovers to local firms in Costa Rica: From theory to evidence", in OECD Economic Survey of Costa Rica 2018: Research findings on productivity from firm-level, trade and sectoral data, OECD Publishing, Paris (forthcoming).

Song, J. et al. (2015), Firming Up Inequality, National Bureau of Economic Research, Cambridge, MA. http://dx.doi.org/10.3386/w21199.

UCCAEP (2011), IV Encuesta Trimestral de Negocios "Pulso Empresarial” 2011, Unión Costarricense de Cámaras y Asociaciones del Sector Empresarial Privado, San José. http://uccaep.or.cr/images/content/pulsoempresarial/2011/IV\%20ETN\%202011\%20prensa.pdf.

World Bank (2017), "Doing Business 2018: Reforming to Create Jobs", A World Bank Group Flagship Report, World Bank, Washington D.C. 